
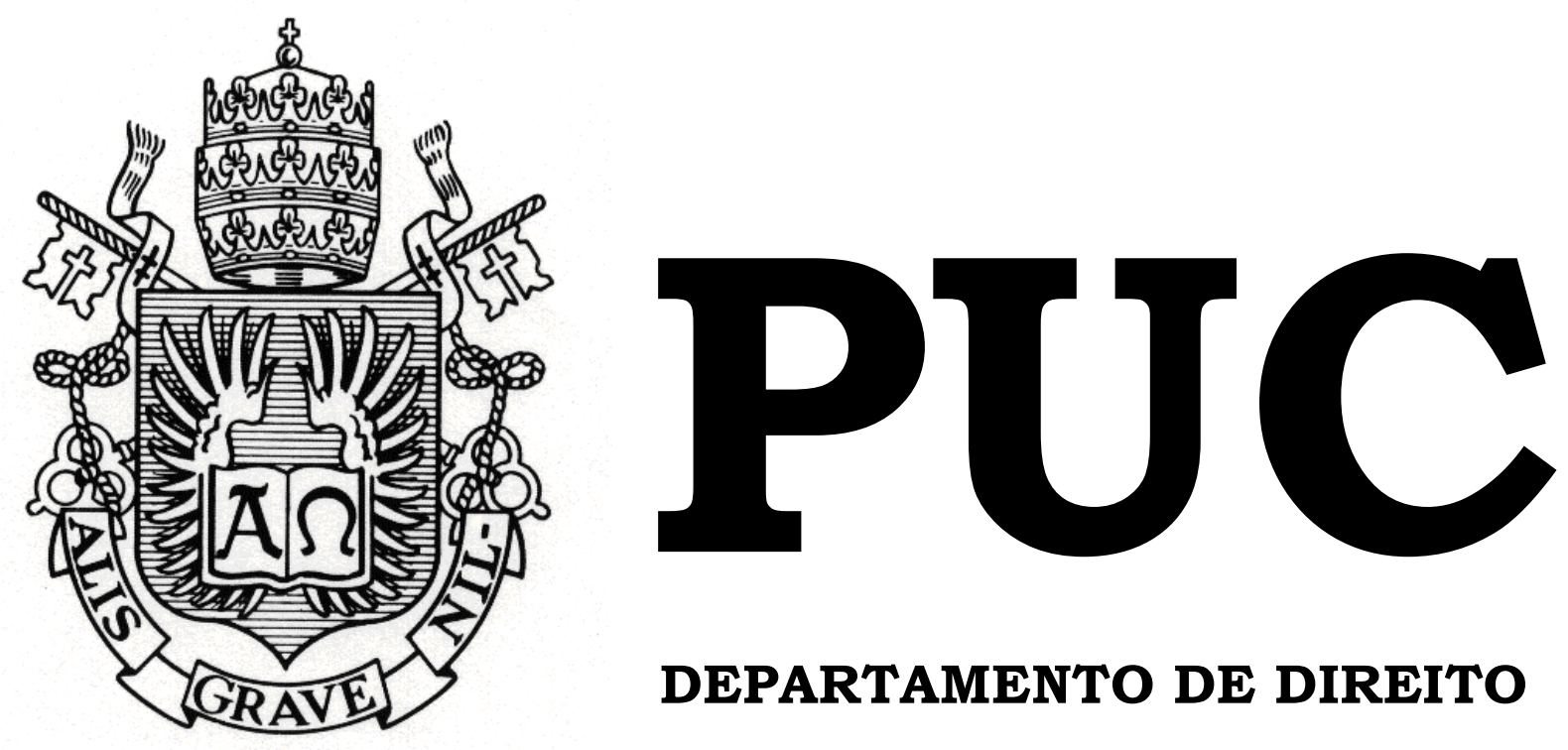

DEPARTAMENTO DE DIREITO

\title{
A CRIMINOLOGIA MIDIÁTICA E SEUS EFEITOS SOBRE A EFETIVAÇÃO DA PRESUNÇÃO DE INOCÊNCIA
}

\author{
por \\ CAROLINA SILVEIRA LOBIANCO E SOUZA
}

ORIENTADOR: Leonardo de Souza Chaves

2019.2

PONTIFÍCIA UNIVERSIDADE CATÓLICA DO RIO DE JANEIRO

RUA MARQUÊS DE SÃO VICENTE, 225 - CEP 22453-900

RIO DE JANEIRO - BRASIL 


\title{
A CRIMINOLOGIA MIDIÁTICA E SEUS EFEITOS SOBRE A EFETIVAÇÃO DA PRESUNÇÃO DE INOCÊNCIA
}

\author{
por \\ CAROLINA SILVEIRA LOBIANCO E SOUZA
}

Monografia apresentada ao

Departamento de Direito da

Pontificia Universidade Católica do

Rio de Janeiro (PUC-Rio) para a obtenção do Título de Bacharel em Direito.

Orientador: Leonardo de Souza Chaves 


\section{AGRADECIMENTOS}

À minha família, especialmente ao meu pai, à minha mãe, às minhas avós e à Mell, por toda forma de apoio prestada.

Ao Guilherme, pelo tanto de amor e de incentivo que me proporcionou nessa etapa.

Às minhas amigas e aos meus amigos, especialmente Natália Ferreira, Vitória Bastos, Maria Carolina Soares, Maria Vitoria Jacob, Alice Mendes e Carol Gonzaga, pela ajuda e leveza que trouxeram a essa caminhada.

Aos colegas do escritório Arthur Lavigne Advogados Associados, em especial Allan Caetano Ramos, Arthur Bruno Fischer e João Vicente Tinoco, por tanto aprendizado.

A todos os meus professores, em especial meu orientador, Leonardo de Souza Chaves, por tanto ensinamento e por toda força. 


\section{RESUMO}

O presente trabalho tem por objetivo analisar criticamente o discurso dos meios de comunicação social sobre a questão criminal e o seu impacto sobre a pouca efetividade de garantias penais, em especial o direito à presunção de inocência. Para tanto, traz, inicialmente, uma investigação histórica de discursos criminológicos com o fito de demonstrar as consequências de um pensamento autoritário para a ineficácia de tal direito fundamental e para o agigantamento do poder punitivo. Depois, expõe as principais características da palavra midiática sobre o delito, considerando as plataformas de comunicação tradicionais e as digitais, o que faz com a intenção de evidenciar a sua proximidade com teorias autoritárias do passado. Em seguida, define o significado, o âmbito de proteção e a importância da presunção de inocência, com base na construção doutrinária e legal sobre este direito. Por outro lado, revela o desprezo recebido pelo estado de inocência na prática dos Tribunais brasileiros e a contribuição significativa que o discurso da mídia sobre a conduta desviante apresenta para o referido cenário. Por fim, este trabalho aponta razões relevantes para a pronta rejeição do referido discurso por meio de uma análise criminológica de massacres perpetrados ao longo da história, bem como de um exame do conflito normativo entre liberdade de expressão e presunção de inocência.

Palavras chave: Criminologia midiática; discursos sobre a questão criminal; liberdade de expressão; poder punitivo; presunção de inocência. 


\section{SUMÁRIO}

INTRODUÇÃO

6

1 CONSIDERAÇÕES SOBRE O PODER PUNITIVO, OS DISCURSOS ACERCA DA QUESTÃO CRIMINAL E A PRESUNÇÃO DE INOCÊNCIA NA HISTÓRIA ....................................9

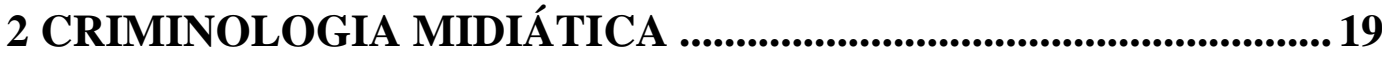

2.1 A repercussão da questão criminal na grande mídia ............................... 22

2.2 Os impactos das novas tecnologias e das fake news .............................. 41

3 PRESUNÇÃO DE INOCÊNCIA: UMA GARANTIA MÍNIMA DE SEGURANÇA E DE LIBERDADE EM RISCO........................................56

4 TEMERIDADE DA RELAÇÃO CRIMINOLOGIA MIDIÁTICA PRESUNÇÃO DE INOCÊNCIA ........................................................... 79

4.1 Uma análise por meio dos mortos ………………................................. 79

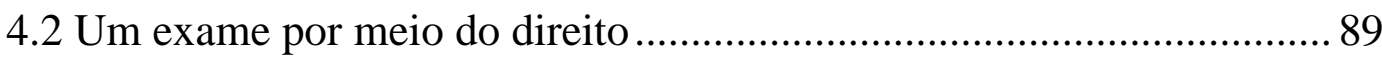

CONCLUSÃO

REFERÊNCIAS BIBLIOGRÁFICAS ...................................................... 106 
“As garantias não são inventos para encobrir criminosos, como pretende a criminologia midiática, e sim resultado das experiências massacradoras anteriores dos Estados policiais."

Eugenio Raúl Zaffaroni 


\section{INTRODUÇÃO}

A atual ascensão do ultraconservadorismo que se sucede no Brasil e em outros países do mundo ocidental convida a pensar sobre seus motivos e consequências. Dentro de diversos porquês, o papel central do sistema penal na atuação política chama atenção. Os discursos encontrados sobre a questão criminal na história e na academia são diversos, mas no senso comum impera o ditado pelos meios de comunicação social.

Dos discursos mais funcionais ao poder punitivo encontra-se o dos veículos de comunicação de massa, chamado pelo eminente professor Zaffaroni de criminologia midiática. O noticiário de todos os dias sobre fatos, investigações e processos penais impulsiona um credo criminológico, nas palavras de Nilo Batista, que naturaliza, de forma acrítica, a pena e todos os controles adjacentes a ela.

A mídia consegue concentrar praticamente todo o mal do mundo no sujeito que é dito "criminoso" e que se torna insuscetível de identificação com o cidadão comum. Logo, combater estes pretensos inimigos surge como uma das prioridades governamentais, nem ao menos de uma forma que se aproxime da racionalidade, mas com o duro emprego do poder punitivo a saciar a ânsia por vingança cega e duradoura que é estimulada.

Pierre Bourdieu, em 1997, já temia que a televisão não explorasse o "extraordinário instrumento de democracia direta" para o qual tinha potencial, mas se tornasse um "instrumento de opressão simbólica"1. O sociólogo francês estava coberto de razão. Hoje, a televisão e seus similares majoritariamente ocultam a barbárie do controle repressivo e provocam no meio social desprezo até mesmo contra direitos fundamentais previstos nas revoluções burguesas do século XVIII.

\footnotetext{
${ }^{1}$ BOURDIEU, Pierre. Sobre a televisão. Rio de Janeiro, Zahar, 1997. P. 13.
} 
A presunção de inocência é uma destas garantias. Cuida-se da imposição de que todo o acusado seja tratado como inocente até a eventualidade de ser declarado culpado. Nos termos de Ferrajoli, é um princípio fundamental da civilidade.

No entanto, a presunção de inocência constitui uma limitação ao poder de punir que, dentro de uma lógica autoritária, deve ser rejeitada, junto de outras normas que provoquem efeitos similares, como o direito à privacidade, à honra, à imagem, à ampla defesa e ao devido processo legal.

Dado isto, este trabalho apresenta o discurso dos grandes meios de comunicação sobre a questão criminal e o impasse que ele traz à observação da presunção de inocência. Sustenta-se que a ideologia midiática é perigosa para o campo social, bem como para a área do direito, considerando um pensamento garantista com fim deslegitimante da pena.

O desenvolvimento da referida tese inicia-se pela importante parte histórica que lança luz sobre como a presunção de inocência dialoga com modelos estatais menos repressivos e com discursos pouco autoritários.

Em seguida, são analisadas, separadamente, a criminologia midiática $^{2}$ e a presunção de inocência. Restará nítida a forma como os meios de comunicação social ultrapassam a mera função comunicativa. Equivalem a um aparato do sistema penal e investem contra as menores das garantias.

A atual era tecnológica de smartphones e redes sociais não poderá ser deixada de lado. Ela modifica a dinâmica comunicacional produzindo, com frequência, um requinte do apoio impensado às práticas de vigilância, controle e punição.

Na sequência, aprofunda-se o porquê se deve temer este discurso e suas consequências. Uma análise dos maiores massacres da história o

\footnotetext{
${ }^{2}$ Apesar de a criminologia midiática ser mais ampla, este trabalho se deterá às expressões da mídia tradicional (composta por jornal, rádio e televisão), bem como da mídia digital (composta por sites e redes sociais da internet).
} 
evidencia. Também o faz um fidedigno exame das normas de direito que estão em jogo na oposição entre o pensamento midiático e as garantias fundamentais. Será que as mortes em grande escala foram produto do "criminoso" que reside na esquina ou do aparato punitivo estatal? Será que a liberdade de imprensa empregada para espetacularizar o crime é protegida pelo direito à liberdade de expressão?

Por fim, é feito um convite para pensar em medidas que possam solucionar o grave problema retratado.

A elaboração do pensamento aqui esboçado é fruto de uma reflexão crítica do papel que o sistema penal desenvolve na sociedade influenciada pela leitura de renomados autores como Eugenio Raúl Zaffaroni, Michel Foucault, Nilo Batista, Vera Malaguti, entre outros. 


\section{CONSIDERAÇÕES SOBRE O PODER PUNITIVO, OS DISCURSOS ACERCA DA QUESTÃO CRIMINAL E A PRESUNÇÃO DE INOCÊNCIA NA HISTÓRIA}

A experiência proporciona conhecimento e transmite advertências sobre a vida. A relevância da investigação histórica para a compreensão dos seres humanos não é olvidada por este trabalho. Na verdade, o texto parte da investigação de antecedentes para admitir conclusões e é todo permeado por considerações históricas.

Neste momento inicial, pretende-se assinalar as relações que existem entre poder punitivo, discurso criminológico e presunção de inocência por meio de uma perspectiva da história. Antes de adentrar propriamente às reflexões sobre a punição, o discurso e a garantia ao longo dos tempos, é preciso situar, ainda que humildemente, suas respectivas definições.

De acordo com uma análise magistralmente elaborada por Zaffaroni $^{3}$, os seres humanos sempre se relacionam entre si e estabelecem vínculos harmoniosos ou conflituosos, bem como estruturas de poder que organizam sua existência.

O penalista destaca que, há muito tempo, uma das maneiras mais formidáveis de organização social e exercício de poder consiste na prática punitiva. Desde o Império Romano, o poder de punir se coloca como um eficaz método de hierarquizar uma sociedade internamente e expandir domínios em escala internacional ou até mesmo planetária.

Isto decorre da característica diferenciada do poder punitivo que é confiscar determinado conflito de interesses entre particulares adquirindo enorme capacidade de decisão sobre a sociedade. Explicando mais nitidamente, Zaffaroni contribui para definir que o poder punitivo tem por

\footnotetext{
${ }^{3}$ ZAFFARONI, Eugenio. O inimigo no direito penal. $3^{\text {a }}$ ed.. Rio de Janeiro: Revan, 2007. P. 2931.
} 
principal elemento usurpar o lugar de quem sofre um dano, modernamente definido como crime. Deste modo, veda a autotutela punitiva ou o exercício privado das próprias razões e institucionaliza a punição e a vingança.

O professor afirma que esta enorme capacidade do poder de punir permite que quem o exerça, notadamente os dominantes do poder público, (i) escolha quais condutas humanas são danosas ou criminosas; (ii) vigie toda a sociedade para que faça valer suas regras; (iii) selecione quais pessoas se submeterão, de fato, ao método de solução de conflitos mencionado; e (iv) determine em que medida e de que forma os sujeitos devem responder pelo desvio ou crime que cometeram.

A essência do poder punitivo compreende, ainda, a seletividade discriminatória, em razão da arbitrariedade nas escolhas mencionadas, e a violência real, em virtude do monopólio do constante uso da força.

Assim como qualquer expressão de poder significativa ${ }^{4}$, a prática punitiva é acompanhada por discursos que lhe dão suporte - dentre os quais o midiático, sobre o que será falado mais adiante - e discursos que lhe deslegitimam. Trata-se de teorias que pensam o aparato punitivo de formas funcionais ou disfuncionais ao referido poder.

Neste contexto, traz-se à baila a presunção de inocência. Em linhas gerais, é possível defini-la como regra que tende a frear o potente instrumento de controle dos indivíduos que é o poder de punir. Em outros termos, é possível conceituá-la como garantia jurídica que limita a violência de Estado.

Percebe-se, portanto, que a relação da presunção de inocência com o poder punitivo é da própria essência desta norma. Importante lembrar que a referida regra não adveio tão-somente da abstração humana. Na verdade, possui estreitos laços com o desenvolvimento da civilização ocidental e com o advento do Estado Democrático de Direito, conceituado como

\footnotetext{
${ }^{4}$ O poder se exerce com o discurso. Cf. Id. A questão criminal. Rio de Janeiro: Revan, 2013. P. 261.
} 
conquista histórica que limita o poder do Estado pelo direito - através de garantias fundamentais - e legitima o poder político estatal pelo povo através de sufrágio universal e participação popular na tomada de decisões ${ }^{5}$.

Feitas tais definições, o presente trabalho passa às considerações acerca dos antecedentes históricos da prática do poder punir, das teorias sobre o sistema penal e da referida garantia jurídica, a partir, principalmente, da obra A Questão Criminal de Eugenio Raúl Zaffaroni.

O começo desta análise deve se dar pelo Império Romano. A consolidação de uma estrutura extremamente hierarquizada, montada mediante o poder punitivo e marcada pela militarização da sociedade, ensejou o primeiro esboço da presunção de inocência.

$\mathrm{O}$ escrito do imperador Trajano "satius esse impunitum relinqui facinus nocentis, quam innocentem damnare" é recordado por Ferrajoli ${ }^{6}$, bem como a máxima de Paulo "ei incumbit probatio qui dicit non qui negat" e os brocardos medievais "affirmanti non neganti incumbit probatio" e "actore non probante reus absolvitur".

Depois da queda do Império Romano até pouco antes dos anos 1000, o poder punitivo se aquietou, o que reduziu também a necessidade de presumir a inocência de imputados.

No entanto, durante o período feudal da Idade Média, o exacerbado poder católico deu origem à Inquisição na Europa Ocidental. O também chamado Tribunal do Santo Ofício organizou o sistema punitivo de forma agigantada e assustadora.

A título de ilustração, as condutas reprovadas equivaliam a pecados determinados arbitrariamente pela Igreja Católica. Já os acusados consistiam em inimigos declarados da Igreja, desde as "bruxas" até o Satã.

\footnotetext{
5, CASARA Rubens R R. Processo penal do espetáculo: e outros ensaios. $2^{\mathrm{a}}$ ed.. Florianópolis: Tirant lo Blanch, 2018. P. 25.

${ }^{6}$ FERRAJOLI, Luigi. Direito e razão: teoria do garantismo penal. $3^{\text {a }}$ ed.. rev. São Paulo: Editora Revista dos Tribunais, 2002. P. 501.
} 
Os processos caracterizavam-se pelo segredo que representavam até a condenação. Além disso, os próprios acusadores prolatavam as sentenças, acumulando para si as divergentes funções de imputar, instruir e julgar os casos. A tortura tratava-se de prática amplamente difundida como forma de obter a confissão do investigado e a verdade configurava um bem de elevado valor que deveria ser exposto a todo custo. As execuções, por sua vez, eram suplícios traduzidos em rituais ostentados com vigor em praça pública que impunham intenso sofrimento aos sentenciados e, muitas vezes, terminavam por matá-los.

A prática punitiva inquisitorial, inicialmente assumida pelo Papa, foi também adotada por soberanos do Estado absolutista por meio de juízes estatais que deles dependiam. O sistema inquisitorial era "prática comum da justiça que acompanhou a revolução mercantil e o colonialismo".? Encontravam apoio discursivo em demonólogos como Heinrich Kramer e Jakob Sprenger. Em $O$ martelo das bruxas, estes dois escreveram sobre a origem e as manifestações desses delitos ou pecados que entendiam como o "mal", bem como sobre como se investiga o mencionado "mal".

Inevitavelmente, a presunção de inocência não detinha espaço nesta estrutura autoritária e atroz. Pelo contrário. Segundo Foucault, cada indício da prática delituosa, por menor que fosse, tornava o acusado culpado de acordo com a relevância da informação. Isto é, uma meia-prova tornava o investigado meio-culpado. E como meio-culpado, o possível delinquente sofreria um certo grau de castigo, pois "não se podia ser inocentemente objeto de suspeita."

Já na segunda parte do século XVIII, a classe burguesa em ascensão buscou seu espaço de poder e se voltou contra a potestade do monarca.

\footnotetext{
${ }^{7}$ ZAFFARONI, Eugenio Raúl. O inimigo no direito penal. $3^{\mathrm{a}}$ ed.. Rio de Janeiro: Revan, 2007. P. 39.

${ }^{8}$ FOUCAULT, Michel. Vigiar e punir: nascimento da prisão. 42 ${ }^{\mathrm{a}}$ ed.. Rio de Janeiro: Vozes, 2014. P. 44.
} 
Nasceu o Iluminismo que reagiu contra o Antigo Regime e, consequentemente, criticou o sistema inquisitorial medieval.

No campo criminológico, o século da razão produziu o utilitarismo e o contratualismo. Ambos atravessavam a questão criminal com a ideia de livre arbítrio. O primeiro, encabeçado por Bentham, afirmava que o delito era sinal de desordem que deveria ser corrigido pelo espaço de disciplinamento do panóptico. Já o segundo, estabelecido principalmente por Beccaria, dizia que a infração rompia com o contrato social e colocava em risco não apenas a vítima, mas a paz e a vontade sociais, devendo tal violação ser indenizada ou reparada.

É importante notar, como faz Foucault, que a reforma penal liberal modificou a estrutura punitiva com os fins de elidir o poder isolado do príncipe, afastar a crescente contrariedade às sanções estatais e cessar ilegalidades populares conquistadas e toleradas. Não humanizou a punição e tampouco pretendeu fazê-lo. Na verdade, uma nova estratégia do poder de castigar foi desenvolvida. Desejava-se "não punir menos, mas punir melhor; punir talvez com uma severidade atenuada, mas para punir com mais universalidade e necessidade; inserir mais profundamente no corpo social o poder de punir." ${ }^{9}$ Daí aparece a privação da liberdade como pena em si.

Como consequência desta reforma - e não abandono - da técnica de punir, o direito penal liberal afirmou a presunção de inocência, mas não deixou de oscilar quanto a sua aplicabilidade, aponta Ferrajoli. A Declaração Francesa de Direitos do Homem e do Cidadão de 1789 dispunha que "todo acusado é considerado inocente até ser declarado culpado e, se julgar indispensável prendê-lo, todo o rigor desnecessário à guarda da sua pessoa deverá ser severamente reprimido pela lei." Por outro lado, os pensadores por vezes excepcionavam a presunção de inocência, como ilustra a seguinte passagem de Dos Delitos e Das Penas:

\footnotetext{
${ }^{9}$ Ibid. P. 81-82.
} 
Parece que o banimento deveria ser pronunciado contra aqueles que, acusados de um delito atroz, e, com grande probabilidade, mas sem certeza, serão julgados culpados; para tanto, porém, seria necessário um estatuto o menos arbitrário e o mais precioso possível, o qual condenasse ao banimento quem tivesse perto a nação diante da alternativa fatal de temê-lo ou defendê-lo, deixando-lhe, entretanto, o direito sagrado de provar a sua inocência. ${ }^{10}$

Quando o iluminismo penal se tornou insuficiente para a classe que antes o havia impulsionado, perdeu espaço para novos discursos. Com a concentração da população e a propagação de conflitos, o desenvolvimento das cidades urbano-industriais demandou uma redefinição ideológica a fim de manter a ordem instaurada com a revolução burguesa. Então, ganhou destaque a ciência da antropologia criminal, nascida na Itália e importada para a América Latina como primeiro esforço em matéria de criminologia na região, conforme assevera Rosa Del Omo.

Valendo-se da valorização cega do saber científico, o positivismo criminológico foi eficiente "para reforçar a ideologia dominante e para justificar as desigualdades de uma sociedade que proclamava ser fundamentalmente igualitária"11. Na segunda metade do século XIX, métodos próprios das ciências naturais, que valiam para explicar fatos objetivos e determinados, foram aplicados para estudar o humano e a sociedade. As conclusões imediatas foram reducionistas. As posteriores, nefastas. Por meio da observação de presos e da medição do crânio e de outras partes de seus corpos, Lombroso assumiu que a delinquência era causada, não por um fator da sociedade, mas por uma limitação estrutural própria do infrator relacionada ao seu pertencimento a uma linhagem humana inferior.

Assim, a pobreza e outras mazelas da sociedade foram atribuídas às patologias de uma raça distinta que devia obediência e submissão aos superiores em razão de sua involução. Como observa Del Omo, a inferioridade - constatada pela prestigiada ciência - legitimou a intervenção

\footnotetext{
${ }^{10}$ BECCARIA, Cesare Bonesana Marchesi di. Dos delitos e das penas. $3^{\text {a }}$ ed.. São Paulo: Martins Fontes, 2005. P. 87.

${ }^{11}$ OMO, Rosa Del. A América Latina e sua criminologia. Rio de Janeiro: Revan, 2004. P. 45.
} 
do Estado contra aqueles que "resistiam" ao sistema, a saber, delinquentes e revolucionários, bem como contra povos dominados pela Europa do neocolonialismo. Em outras palavras, a criminologia positivista não apenas manteve intacto e sem críticas o sistema dominante, como também justificou uma firme resposta estatal às condutas que este sistema proibia.

Nesta toada de agigantamento do controle social repressivo, é claro que a presunção de inocência foi veementemente atacada. Salienta Ferrajoli que:

Raffaele Garofalo e Enrico Ferri, em coerência com suas opções substancialistas, consideraram "vazia", "absurda" e "ilógica" a fórmula da presunção de inocência, o primeiro exigindo a prisão preventiva obrigatória e generalizada para os crimes mais graves e o segundo aderindo a modelos de justiça sumária e substancial além das provas de culpabilidade. [...] Vincenzo Manzini [...] estigmatizou a fórmula como um "estranho absurdo excogitado pelo empirismo francês" e a julgou "grosseiramente paradoxal e irracional" baseada em uma cadeia de petições de princípio: a apriorística valorização dos institutos positivos da custódia preventiva e do segredo instrutório que por ela seriam contraditados, a insensata equiparação instituída entre os indícios que justificam a imputação e a prova da culpabilidade, a assunção de que a experiência demonstraria que a maior parte dos imputados são na realidade culpados. Reforçado por esses avais, o Código Rocco de 1930 repeliu "por completo a absurda presunção de inocência, que alguns pretendiam reconhecer ao imputado", liquidando-a como "uma extravagância derivada daqueles conceitos antiquados, germinados pelos princípios da Revolução Francesa, os quais levam as garantias individuais aos mais exagerados e incoerentes excessos". ${ }^{12}$

O pensamento essencialmente racista do positivismo criminológico não parou por aí e contribuiu para os massacres da Segunda Guerra Mundial, que incluíram campos de concentração, políticas de eugenia e invasões determinadas pelo objetivo de colonizar todo o planeta.

Repisa-se que a criminologia positivista biologista entende o ser humano como ser puramente biológico que, quando evoluído, deve usar e controlar os demais. Dado este pressuposto, não é difícil entender que nazifascistas pregassem a eliminação dessas raças inferiores que obstavam o progresso dos mais perfeitos e traziam custos indesejáveis nos manicômios e asilos.

\footnotetext{
${ }^{12}$ FERRAJOLI, Luigi. Direito e razão: teoria do garantismo penal. $3^{\mathrm{a}}$ ed.. rev. São Paulo: Editora Revista dos Tribunais, 2002. P. 422.
} 
A criminologia racista e essencialmente punitivista levada às últimas instâncias pelo pensamento da extrema-direita do século XX culminou na profunda crise da presunção de inocência. Ferrajoli aponta que ela chegou a ser negada pela ideologia fascista que "não considera a liberdade individual um direito preeminente, mas sim uma concessão do Estado acordada no interesse da coletividade"13.

No entanto, desta vez, o poder de punir não se restringiu a uma colônia da América. A intervenção destrutiva estatal propagou-se por todo o continente europeu, onde atingiu as classes tradicionalmente dominantes, reprimindo-as. Não por coincidência a necessidade de se limitar o poder punitivo foi, então, finalmente impulsionada com o adequado vigor.

A Declaração Universal dos Direitos Humanos de 1948 cumpriu tal papel normativo e anunciou uma mudança de paradigma no plano mundial. Defendeu a presunção de inocência consolidando que

todo ser humano acusado de um ato delituoso tem o direito de ser presumido inocente até que a sua culpabilidade tenha sido provada de acordo com a lei, em julgamento público no qual the tenham sido asseguradas todas as garantias necessárias à sua defesa.

Desde então, os principais discursos acadêmicos que se sucederam foram mais sensatos e louváveis. O racismo praticamente desapareceu e a criminologia ontológica foi sendo, finalmente, deixada para trás na academia.

A era dos sociólogos pensantes da questão criminal, no que se destaca o interacionismo, vingou e abriu espaço para a criminologia crítica que, apesar das várias vertentes, é caracterizada por sabiamente incorporar o funcionamento do poder punitivo na análise do crime.

No entanto, a criminologia da reação social é relativamente recente e adentrou esse território dos discursos criminológicos "pela margem

\footnotetext{
${ }^{13}$ Ibid. P. 505.
} 
periférica" ${ }^{14}$, como bem nota Vera Malaguti. Logo o discurso intolerante da "lei e ordem" apareceu na voz de políticos e da grande mídia e, na forma que destaca Malaguti, pediu pela ampliação do aparato punitivo, com penalidades mais severas e garantias mais flexíveis, bem como fortaleceu a pena como solução essencial para os conflitos humanos.

Na contemporaneidade, a prisão mais do que nunca se firmou como forma relevantíssima de se controlar gente, desembocando no encarceramento em massa do século XXI, embora a presunção de inocência esteja positivada em diplomas internacionais, constitucionais e legais. Destaca-se a Convenção Europeia dos Direitos do Homem, o Pacto Internacional sobre Direitos Civis e Políticos, o Pacto de São José da Costa Rica, a Constituição da República Federativa do Brasil de 1988, entre outros.

O presente trabalho termina esta singela abordagem histórica identificando a relação entre prática, teoria e garantia jurídica que foi mencionada no início deste capítulo. A presunção de inocência, como ideia que freia o hierarquizador poder punitivo, viu altos e baixos em decorrência tanto das práticas punitivas quanto dos discursos que as legitimavam. Ao longo dos tempos, os visíveis ataques a esta garantia foram constantemente impostos por Estados mais repressivos que se sustentavam por discursos fundamentalmente autoritários, como a Inquisição ibérica e o Estado fascista de Mussolini. Já o seu louvor foi percebido por modelos estatais que defendiam a igualdade e a liberdade, ou que ao menos diziam fazê-lo, como o Estado capitalista do século XVIII no período pós revolução burguesa e a democracia do pós Segunda Guerra Mundial.

É necessário que hoje não se aproveite do avanço da presunção de inocência, que parece estar bem estabelecida juridicamente, para faltar com atenção ao seu nível de observância na prática. Isto porque o que mais deve

\footnotetext{
${ }^{14}$ BATISTA, Vera Malaguti. Introdução crítica à criminologia brasileira. $2^{\mathrm{a}}$ ed.. Rio de Janeiro: Revan, 2012. P. 114.
} 
preocupar são os discursos historicamente ultrapassados, vistos aqui, que se encontram bem enraizados na imaginação social, alimentando verdadeiros estados de exceção para além da lei, quando não obscuramente no próprio campo jurídico.

A realidade midiática possui estratégica posição neste perigoso contexto, conforme se passa a demonstrar. 


\section{CRIMINOLOGIA MIDIÁTICA}

Na relação entre prática (poder punitivo), discurso (criminologia) e garantia (presunção de inocência), os meios de comunicação de massa atuam por meio do segundo e influenciam os demais. Não é novidade que a questão criminal seja notícia junto aos meios de comunicação exercendo seu papel na criação de determinada realidade social. Os interesses do público e especialmente do comunicador impulsionam há séculos a divulgação de fatos e a criação de histórias sobre delitos, investigações e processos judiciais. Apesar disso, a exploração do crime pelos veículos midiáticos merece especial atenção agora, conforme será evidenciado.

O período inquisitorial foi marcado por uma literatura de folhetins, novelas, almanaques e bibliotecas azuis em que constavam as últimas palavras de um condenado no suplício, bem como as narrativas de crimes e de vidas infames antes de qualquer processo. Curioso que esta forma de discurso, focada na vida do criminoso, em seu confronto com a lei e o poder e em sua dramática execução - muitas vezes arrependido - acabava por glorificar aquele que delinquiu junto à camada popular. É o que assegura Foucault.

Atentos, os reformadores do sistema penal substituíram estas palavras pela literatura policial em que recebe enfoque a fase de investigação e a luta intelectual entre o investigador e o criminoso, agora divulgado como mau, inteligente e, sobretudo, diferente do povo.

Mais tarde, no final do século XIX ganharam força noticiários policiais cotidianos que apresentavam a delinquência como 
muito familiar e, ao mesmo tempo, totalmente estranha, uma perpétua ameaça para a vida cotidiana, mas extremamente longínqua por sua origem, pelo que a move, pelo meio onde se mostra, cotidiana e exótica. ${ }^{15}$

Com este então novo destaque o intuito foi de silenciar as reações negativas ao sistema penal, bem como separar os criminosos das categoriais mais desfavorecidas da sociedade. Foucault continua sua análise reparando que a ruptura total pretendida entre delinquente e camada popular não obteve sucesso, mesmo contanto com o melodrama diário do delito e de sua perseguição nos jornais.

Hoje, a situação parece um pouco diferente. A tática de noticiar fatos criminosos sem nenhuma margem para a epopeia e com muito espaço para o pânico geral se mantém. No entanto, desde a segunda metade do século $\mathrm{XX}$ ela conta com um mecanismo diferente que detém muita notoriedade e alcance incomparável: a televisão.

Tal avassalador instrumento de comunicação revolucionou todo o campo jornalístico - como observa o seu famoso crítico Pierre Bordieu - e atualmente ainda é forma dominante de divulgação de informação em território brasileiro ${ }^{16}$. A transmissão de notícias proporcionada pela TV, a saber, caracterizada pelo uso de imagens que estimulam primordialmente os sentimentos do público, era o que faltava para o pleno êxito das práticas punitivas contra as condutas desviantes perseguidas como crimes. As especificidades da palavra da imprensa na contemporaneidade, que há anos se somam, desembocam no sucesso inimaginável do poder punitivo e na centralidade sem precedentes do direito penal na vida política.

Ademais, a internet possibilitou novos usos para os gigantes da comunicação, bem como diversificou os agentes de produção de notícias. Importante notar que, em um universo de conteúdo, os mecanismos da rede

15 FOUCAULT, Michel. Vigiar e punir: nascimento da prisão. 42 ${ }^{\mathrm{a}}$ ed.. Rio de Janeiro: Vozes, 2014. P. 281.

${ }^{16}$ Cf. NEWMAN, Nic; FLETCHER, Richard; KALOGEROPOULOS, Antonis; LEVY David A. L.; NIELSEN, Rasmus Kleis. Reuters Institute Digital News Report 2018. Oxford: Reuters Institute for the study of journalism, 2018. Disponível em: < http://media.digitalnewsreport.org/wp-content/uploads/2018/06/digital-news-report2018.pdf?x89475 >. Acesso em 26/08/2019. P. 116. 
mundial de computadores e smartphones funcionam filtrando publicações de acordo com o interesse de cada usuário. É comum que esta bolha virtual se combine ou se alterne com uma quantidade excessiva de informações rápidas e simples. Isto é dizer que, em regra, se tem uma circulação de matérias que pouco demandam esforços reflexivos do sujeito navegador, bem como uma ocultação de temas que sejam indiferentes a ele. Portanto, rasas visões de mundo desfrutam de enorme potencial para se perpetuarem ou até se engrandecerem no que se refere ao pensamento sobre os mais diversos campos da existência, incluindo o sistema penal.

Antes de mais nada, importa fazer duas ressalvas. A primeira compreende salientar que não se olvida da imprescindibilidade da imprensa para a consolidação de um efetivo Estado Democrático de Direito. Por outro lado, deve-se lembrar que sua relevância depende de o mecanismo de comunicação social ser independente do poder político e econômico, bem como livre de censuras prévias e de outras amarras. Tais elementos, essenciais para a contribuição da imprensa ao desenvolvimento de uma sociedade justa, igualitária e emancipada, sofrem com o vínculo promíscuo entre os meios informacionais e o poder - típico da mídia hegemônica, especialmente no que toca seu discurso sobre a questão criminal, conforme será visto a seguir.

A segunda ressalva consiste em destacar que a crítica a ser feita neste trabalho não se estende a todo e qualquer órgão midiático. De fato, existem organismos no campo jornalístico - seja na televisão, seja online - que se importam com o uso verdadeiramente democrático da comunicação de massa a englobar a exposição de conhecimento, o debate profundo de ideias, a fiscalização das estruturas de poder e o incômodo de contestar a ordem vigente. No entanto, a falta de unanimidade não impede que setores mais amplos e notórios do campo midiático explorem a questão criminal em consonância com seu apego pelo controle social repressor e autoritário. 
Ultrapassado este introito e vista a relevância que se deve dar à criminologia midiática no presente momento histórico, passa-se para a avaliação, com maior profundidade, de como se dá o principal discurso dos veículos de informação sobre o crime, quais são os motivos que o impulsionam e quais os efeitos que dele decorrem. Agora será analisada a comunicação efetuada pela grande mídia, que aqui é definida como o complexo de órgãos comunicacionais tradicionais, atuantes na televisão, na rádio e nos jornais, que detêm relevante domínio de produção e transmissão informacional, bem como significativo alcance dentro da sociedade.

\subsection{A repercussão da questão criminal na grande mídia}

Rubens Casara afirma que os meios de comunicação social operam como verdadeiros agentes do sistema pena ${ }^{17}$. Para que se entenda totalmente esta afirmação, explica-se em pormenores o funcionamento da criminologia midiática com principal fundamento nas reflexões de Pierre Bordieu em sua obra crítica Sobre a televisão e de Eugenio Raúl Zaffaroni em A questão criminal.

O primeiro ponto a se destacar é a homogeneidade do produto jornalístico. As informações escolhidas para serem divulgadas pela grande mídia são extremamente semelhantes entre si, mesmo que veiculadas em diferentes órgãos midiáticos e produzidas por distintos jornalistas. De acordo com Bordieu, isto decorre das restrições impostas pelas fontes e, principalmente, pela lógica da concorrência que existe no mundo midiático desde a televisão.

O sociólogo explica que os jornalistas têm propriedades em comum de condição, de formação e de origem, assim como leem uns aos outros na imprensa escrita, veem uns aos outros no televisor, encontram-se

\footnotetext{
${ }^{17}$ CASARA, Rubens R R. Processo penal do espetáculo: e outros ensaios. $2^{\mathrm{a}}$ ed.. Florianópolis:
} Tirant lo Blanch, 2018. P. 13. 
constantemente em eventos e estão igualmente expostos à exigência de sucesso comercial. Nesta "espécie de jogo de espelhos refletindo-se mutuamente" produz-se "um formidável efeito de barreira, de fechamento mental" 18 e o encerramento de um "círculo vicioso da informação"19. Com isso, a exclusão de notícias pertinentes para o exercício de direitos democráticos é uma realidade.

Neste conjunto de notícias extremamente similares entre si, um dos tópicos mais explorados, enquanto outros são ocultados, é a questão criminal. Os órgãos midiáticos se dedicam massivamente ao fenômeno da criminalidade ao ponto de produzirem um verdadeiro bombardeio diário de matérias que envolvem delitos, investigações policiais e processos judiciais. Francesco Carnelutti afirmou, em 1957, que a mídia apaixonava as pessoas pelo tema de condutas desviantes. Ele explicou que as vidas cinzentas, monótonas e amargas dos indivíduos os moviam para a evasão da realidade encontrada na diversão e no seu oposto, o drama, bem assumido pela veiculação do delito.

O grande interesse do público pela delinquência é bastante considerado pelo campo midiático tradicional - o que inclui o jornalismo e o entretenimento - principalmente pela lógica comercial que o circunda. Esta lógica aponta para o efeito pouco democrático de se transmitir o conteúdo que mais venda ou eleve o índice de audiência. Não apenas este, mas muitos outros são os motivos que impulsionam o elevado número de matérias sobre o fato criminoso. Importa agora destacar que a quantidade inumerável de reportagens similares sobre o crime que, como foi visto, há anos se acumula, desemboca na construção de uma obviedade. A precoce ingestão de determinado conteúdo acerca da questão criminal cria insinuações relativas ao crime que se tornam óbvias no campo social, o que inclui o campo da política ${ }^{20}$. Afinal, "é o que mostra a televisão, é o que

\footnotetext{
${ }^{18}$ BOURDIEU, Pierre. Sobre a televisão. Rio de Janeiro, Zahar, 1997. P. 33.

${ }^{19}$ Ibid. P. 35.

${ }^{20}$ ZAFFARONI, Eugenio Raúl. A questão criminal. Rio de Janeiro: Revan, 2013. P. 213-216.
} 
todos comentam entre si, é o que se verifica naquilo que me contam na fila do ônibus ou na padaria."21

Parte desta obviedade - que será analisada mais adiante - pode ser explicada também por uma terceira característica da criminologia midiática. O discurso da grande mídia sobre o crime é o único que atinge as pessoas em geral. Isto é dizer que a sociedade conhece o delito tão somente pela perspectiva do campo jornalístico. Zaffaroni afirma que

as pessoas que todos os dias caminham pelas ruas e tomam o ônibus e o metrô junto a nós têm a visão da questão criminal que é construída nos meios de comunicação, ou seja, se nutrem - ou padecem - de uma criminologia midiática. ${ }^{22}$

Isto porque, com a exceção de estudiosos especializados em criminologia, os indivíduos não dedicam seu reduzido tempo - a urgência é uma característica da contemporaneidade - a se aprofundar neste e em outros assuntos que escapem a sua necessidade cotidiana. A mídia se estabelece como uma fonte única de informações sobre diversos assuntos de forma que "tem uma espécie de monopólio de fato sobre a formação das cabeças de uma parcela muito importante da população." 23 No que se refere à questão criminal, o público - a incluir políticos e agentes do sistema penal - não escuta a palavra da história, da academia ou dos mortos sobre o delito, sua razão de ser e o que se deve fazer com ele. Na verdade, o campo social se detém a uma única análise homogênea, massiva e factual do crime - que é a quarta característica do discurso midiático a ser abordada.

A imprensa escolhe divulgar casos delituosos, o que inclui o ato criminoso em si, as diligências da investigação e as decisões judiciais propriamente ditas. Pouco se vê de dados estatísticos ou de pesquisas acadêmicas ocupando as manchetes de jornais e as reportagens de televisão. A observação de que a execução da pena é raríssimas vezes noticiada e, quando é, isto é feito de forma inteiramente diversa, é de extrema

\footnotetext{
${ }^{21}$ Ibid. P. 198.

22 Ibid. P. 194.

${ }^{23}$ BOURDIEU, Pierre. Sobre a televisão. Rio de Janeiro, Zahar, 1997. P. 23.
} 
relevância e será ventilada mais à frente. Cumpre agora entender que o campo jornalístico veicula o delito de forma específica e individualmente considerada. É o que se percebe ao ligar a televisão e ao folhear os jornais. É o que constatam também as pesquisas sobre a cobertura que os jornais impressos do país fazem a respeito da violência urbana e da segurança pública elaboradas pelo Centro de Estudos de Segurança e de Cidadania da Universidade Candido Mendes em $2006^{24}$ e em $2015^{25}$.

A divulgação extremamente superficial das condutas desviantes é uma constância primeiro porque se adequa à lógica mercadológica do jornalismo. $\mathrm{O}$ delito divulgado como variedade sensacional ou extraordinária alcança considerável notoriedade que, em outras palavras, significa o sucesso comercial. Além disso, alimenta um desejado vazio em modificação política enquanto mantém intactas as estruturas mentais de uma moral pequeno-burguesa, conforme se depreende de Bordieu. A mídia escolhe preferencialmente acontecimentos como o uso de um véu religioso na escola e a agressão de um professor para suscitar "indignações patéticas [...] ou considerações moralizantes" ${ }^{26}$. Seleciona, ainda, casos como raptos de crianças e escândalos que causem a indignação popular, eis que

podem despertar um imenso interesse ao adular as pulsões e as paixões mais elementares [...] ou mesmo formas de mobilização puramente sentimentais e caricativas ou, igualmente passionais, porém agressivas e próximas do linchamento simbólico, com os assassinatos de crianças ou os incidentes associados a grupos estigmatizados. ${ }^{27}$

Segundo porque a notícia pouco ou nada abrangente acerca da questão criminal é rápida e fácil de se produzir. É comum que qualquer jornalista, sem precisar de conhecimento específico, receba informações sobre fatos delituosos de agências do sistema penal e apenas reproduza-as

\footnotetext{
${ }^{24}$ Cf. RAMOS, Silvia; PAIVA, Anabela. Mídia e violência: tendências na cobertura de criminalidade e segurança no Brasil. Rio de Janeiro: IUPERJ, 2007.

${ }^{25}$ Cf. RAMOS, Silvia; PAIVA, Anabela; NUNES, Pablo. Mídia e violência: O que mudou em uma década? - Relatório preliminar de análise de jornais impressos. Rio de Janeiro: Centro de Estudos de Segurança e Cidadania (CESEC) / Universidade Cândido Mendes, mai. 2017. Disponível em: < https://www.ucamcesec.com.br/wp-content/uploads/2016/10/Midia-eViolencia_2016_Versao4.pdf $>$. Acesso em 13/08/19. 39 p.

${ }^{26}$ BOURDIEU, Pierre. Sobre a televisão. Rio de Janeiro, Zahar, 1997. P.74.

${ }^{27}$ Ibid. P. 74.
} 
em matérias que serão veiculadas em canais de televisão ou em páginas dos jornais.

As referidas pesquisas da Universidade Cândido Mendes são firmes em apontar que o jornalismo brasileiro de segurança pública era extremamente dependente das informações policiais em 2004 e continuou assim uma década depois ${ }^{28}$. Além disso, condutores de grandes operações como a Mãos Limpas na Itália ${ }^{29}$ e a Lava Jato no Brasil ${ }^{30}$ abusaram da divulgação de informações jurídico-penais específicas com o fim de pressionar demandados e angariar apoio público por meio da espetacularização de investigações e processos penais individualmente considerados.

Assim, a recorrente apresentação de casos criminais específicos é alimentada pelo sucesso comercial, bem como pelo pequeníssimo custo de produzir uma notícia que não requer a especialização do jornalista em matéria criminal e que se aproveita da propensão de atores penais divulgarem informações sobre casos determinados.

\footnotetext{
${ }^{28}$ RAMOS, Silvia; PAIVA, Anabela; NUNES, Pablo. Mídia e violência: O que mudou em uma década? - Relatório preliminar de análise de jornais impressos. Rio de Janeiro: Centro de Estudos de Segurança e Cidadania (CESEC) / Universidade Cândido Mendes, mai. 2017. Disponível em: < https://www.ucamcesec.com.br/wp-content/uploads/2016/10/Midia-eViolencia_2016_Versao4.pdf >. Acesso em 13/08/19. P. 26.

29 "Os responsáveis pela operação mani pulite ainda fizeram largo uso da imprensa. [...] a investigação da 'mani pulite' vazava como uma peneira. Tão logo alguém era preso, detalhes de sua confissão eram veiculados no 'L'Expresso', no 'La Republica' e outros jornais e revistas simpatizantes. Apesar de não existir nenhuma sugestão de que algum dos procuradores mais envolvidos com a investigação teria deliberadamente alimentado a imprensa com informações, os vazamentos serviram a um propósito útil. O constante fluxo de revelações manteve o interesse do público elevado e os líderes partidários na defensiva. [...] A publicidade conferida às investigações teve o efeito salutar de alertar os investigados em potencial sobre o aumento da massa de informações nas mãos dos magistrados, favorecendo novas confissões e colaborações. Mais importante: garantiu o apoio da opinião pública às ações judiciais, impedindo que as figuras públicas investigadas obstruíssem o trabalho dos magistrados, o que, como visto, foi de fato tentado. [...] As prisões, confissões e a publicidade conferida às informações obtidas geraram um círculo virtuoso, consistindo na única explicação possível para a magnitude dos resultados obtidos pela operação mani pulite." Cf. MORO, Sergio Fernando. Considerações sobre a operação mani pulite. Revista CEJ, Brasília, n. 26, p. 56-62, jul./set. 2004. Disponível em < https://www.conjur.com.br/dl/artigo-moro-mani-pulite.pdf>. Acesso em 01/09/2019.

${ }^{30}$ Para mais informações ver GREENWALD, Glenn; NEVES, Rafael. As mensagens secretas da Lava Jato Parte 18: Em chats, procuradores admitem "vazamentos". Num episódio, Dallagnol antecipou passo da operação ao Estadão para pressionar suspeito. The Intercept Brasil, 29 ago 2019. Disponível em: < https://theintercept.com/2019/08/29/lava-jato-vazamentos-imprensa/ >. Acesso em 01/09/19.
} 
A implicação da referida abordagem consiste em permitir a identificação dos sujeitos que oficialmente delinquiram e, por conseguinte, propagar a falsa percepção de que apenas estes indivíduos perseguidos pelo sistema penal cometem crimes. Há toda uma cifra oculta e extraoficial sobre a qual não se fala e, consequentemente, não se pensa. Há, ainda, uma seletividade do poder punitivo que se volta contra os vulneráveis de uma sociedade sobre a qual sequer se sonha. Explica-se.

No primeiro volume da obra Direito Penal Brasileiro, Nilo Batista e Raúl Zaffaroni esclarecem muito bem que não é o simples atuar contrário à norma penal que condiciona a repressão punitiva, mas a situação de vulnerabilidade. Segundo os penalistas, o sistema penal é caracterizado pela existência de uma imensidão de normas incriminadoras que se contrapõe a um aparato relativamente reduzido de persecução penal. Em razão desta desproporção, o aparato criminal nunca é capaz de repreender todas as condutas que se amoldam às infrações previstas em lei. Este cenário culmina na seleção de uma parte ínfima de delitos à qual será aplicada a norma penal, notadamente a fração cometida pelos mais vulneráveis ${ }^{31}$, enquanto uma grande quantidade de crimes praticados pelas mais variadas camadas da sociedade se mantém na obscuridade. A despeito disso, a mídia confunde o criminalizado com o criminoso e desinforma o público no momento em que

\footnotetext{
${ }^{31}$ De acordo com Batista e Zaffaroni, a criminalização secundária - que é a seleção de uma parte ínfima dos sujeitos que incorrem nos delitos previstos abstratamente para que esta seja punida pela norma penal - se submete a pressões de vários agentes do sistema penal e fica a cargo do burocrático sistema operacional das agências de persecução penal. Este sistema propicia uma reiteração ritual em que, no geral, se faz o que é mais simples: volta-se contra os fatos brutos ou grosseiros, também chamados de obras toscas da criminalidade, e contra as pessoas que tragam menos problemas para a agência executiva, seja por falta de acesso ao poder político, econômico ou à comunicação de massa. Os criminólogos explicam que, via de regra, os delitos mais facilmente detectados são aqueles cometidos pela camada da sociedade que tem acesso a recursos mais escassos, notadamente a categoria em desvantagem. Em menor frequência, são selecionadas as infrações daqueles que atuaram com brutalidade singular como os autores de homicídios intrafamiliares, de roubos neuróticos, etc. Além disso, muito excepcionalmente, os ilícitos dos que ocupam uma posição praticamente de invulnerabilidade são escolhidos por eles terem levado a pior na luta de poder hegemônico e sofrido uma ruptura nesta cobertura insusceptível ao poder punitivo. Para visualizar a explicação completa vide ZAFFARONI, Eugenio Raul et al. Direito Penal Brasileiro: primeiro volume - Teoria Geral do Direito Penal. $4^{\mathrm{a}}$ ed.. Rio de Janeiro: Revan, 2011. P. 43-53.
} 
os atos mais grosseiros cometidos por pessoas sem acesso positivo à comunicação social acabam sendo divulgados por esta como os únicos delitos e tais pessoas como os únicos delinquentes. A estes últimos é proporcionado um acesso negativo à comunicação social que contribui para criar um estereótipo no imaginário coletivo. Por tratar-se de pessoas desvaloradas, é possível associarlhes todas as cargas negativas existentes na sociedade sob a forma de preconceitos, o que resulta em fixar uma imagem pública do delinquente com componentes de classe social, étnicos, etários, de gênero e estéticos. ${ }^{32}$

Para melhor entender a marginalização e o estereótipo criados pela mídia é imperioso abordar a quinta característica do seu discurso que é a dramatização da questão criminal. O tratamento caso a caso do sistema penal propagado pela imprensa abre margem para a divulgação dramatizada de delitos especialmente dramáticos.

Pierre Bordieu revela que a realidade selecionada e construída pela mídia opera de acordo com a busca do sensacional, do espetacular, do que rompe com o cotidiano. Diante de fatos medíocres deve-se até mesmo pintá-los como se extraordinários fossem. Rebeliões em subúrbios, inundações nas cidades, incêndios, assassinatos e variedades ganham o status de notícia. O furo, conforme afirma o sociólogo, interessa a todo mundo e não toca em nada de importante, sendo perseguido justamente por atingir um público extenso e possibilitar a manutenção da ordem simbólica vigente.

No tocante à questão criminal propriamente dita, os meios de comunicação veiculam condutas como homicídios, estupros e grandes roubos por se amoldarem à mencionada exigência do furo. A gravidade dos delitos, seja em termos quantitativos ou qualitativos, é um pressuposto a ser preenchido para que se tenha uma matéria jornalística. Zaffaroni nota que "são cuidadosamente selecionados os delitos mais carregados de perversidade ou violência gratuita; os outros são minimizados ou apresentados de forma diferente". 33

\footnotetext{
32 Ibid. P. 46.

${ }^{33}$ Ibid. P. 197.
} 
Não apenas os fatos criminosos mais inquietantes são preferencialmente escolhidos para serem divulgados de forma ampla, como estes são submetidos a um discurso apelativo, ainda em observância à busca pelo sensacional.

O jornalismo explora a figura da vítima e de seus familiares por meio da realização de entrevistas e da veiculação de imagens anteriores ao delito. Toda a angústia e a dor dos que sofrem com o dano sensibilizam ainda mais quando são transmitidas em vídeo e narradas pelo tom melodramático do apresentador ou repórter. A figura dos delinquentes preferencialmente cometendo delitos é também de extremo valor para os jornalistas. No Rio de Janeiro, é comum que equipes de filmagem trabalhem inclusive em helicópteros para registrar sujeitos com armamento pesado ou em situação de "troca de tiro" com a polícia nos espaços das favelas. Toda a audácia e o perigo dos que cometem crimes choca ainda mais quando são gravadas em vídeo e narradas pelo tom acanhado ou indignado do apresentador ou repórter.

A abordagem dramatizada de delitos específicos desemboca na construção de uma realidade em que determinado grupo de seres humanos frequentemente os vulneráveis que se amoldam a um estereótipo - foge à normalidade, comete condutas desviantes que preocupam e age perigosamente como bárbaro. Não apenas a imagem da delinquência é atribuída a determinado grupo, como também a ideia de transgressores perversos é etiquetada aos seus componentes.

A uma porque a divulgação massiva e homogênea de infrações especialmente impactantes enseja

a suposição coletiva de que as prisões são povoadas por autores de fatos graves ("delitos naturais") tais como homicídios, estupros etc., quando, na verdade, a grande maioria dos prisonizados o são por delitos grosseiros cometidos com fins lucrativos (delitos burdos contra a propriedade e o pequeno tráfico de tóxicos, ou seja, a obra tosca da criminalidade). ${ }^{34}$

\footnotetext{
${ }^{34}$ Ibid. P. 47.
} 
Imagina-se que todos os indivíduos que se amoldam à imagem pública de delinquentes cometeram e cometem as terríveis práticas que convenientemente ganham o status de notícia e que por este motivo foram perseguidos pelo sistema penal e presos. Os dados sobre a população carcerária brasileira desacreditariam tranquilamente o imaginário coletivo de que a repressão penal se volta única ou majoritariamente contra delitos ultrajantes como crimes contra a vida e contra a integridade física da pessoa $^{35}$. Estes dados poderiam ser uma luz no descobrimento por todos dos fins não revelados do sistema penal. No entanto, as estatísticas detêm pouquíssimo espaço nos meios de comunicação social ${ }^{36}$.

A duas porque a camada extra de drama que é combinada a tais crimes selecionados de acordo com a ofensividade dos fatos culmina na disseminação de medo no campo social principalmente pela transmissão audiovisual das notícias sobre o assunto. A comunicação por imagens possibilitada pela televisão impacta diretamente a esfera emocional do público estimulando reações sentimentais às graves informações apresentadas.

Zaffaroni chama atenção para este impacto ${ }^{37}$ e também para a forma como a mídia gerencia e concentra os temores da população ${ }^{38}$. O discurso midiático constrói um ideário de que o criminoso da rua é causador de todo

\footnotetext{
${ }^{35}$ O levantamento do Infopen de Junho de 2016 revelou que significativo numerário de pessoas estão privadas de liberdade por tráfico de drogas e crimes contra o patrimônio. Cf. SANTOS, Thandara; ROSA, Marlene Inês da. Levantamento nacional de informações penitenciárias: INFOPEN Atualização - Junho de 2016. Brasília: Ministério da Justiça e Segurança Pública. Departamento Penitenciário Nacional, 2017. Disponível em: < http://depen.gov.br/DEPEN/noticias-1/noticias/infopen-levantamento-nacional-de-informacoespenitenciarias-2016/relatorio_2016_22111.pdf>. Acesso em 03/10/2019. P. 41-43.

${ }^{36}$ De acordo com a referida pesquisa sobre a cobertura que os jornais impressos do país fazem a respeito da violência urbana e da segurança pública elaborada pelo Centro de Estudos de Segurança e de Cidadania da Universidade Candido Mendes em 2015 tão somente 1,7\% das matérias examinadas tem como foco principal estatísticas ou pesquisas e apenas $8,4 \%$ das matérias examinadas citou estatísticas criminais. Cf. RAMOS, Silvia; PAIVA, Anabela; NUNES, Pablo. Mídia e violência: $\mathrm{O}$ que mudou em uma década? - Relatório preliminar de análise de jornais impressos. Rio de Janeiro: Centro de Estudos de Segurança e Cidadania (CESEC) / Universidade Cândido Mendes, mai. 2017. Disponível em: < https://www.ucamcesec.com.br/wpcontent/uploads/2016/10/Midia-e-Violencia 2016 Versao4.pdf >. Acesso em 13/08/19. P. 15-23; 32 .

${ }^{37}$ ZAFFARONI, Eugenio Raul. A questão criminal. Rio de Janeiro: Revan, 2013. P. 196.

${ }^{38}$ Ibid. P. 194-208.
} 
o mal do mundo, eis que confere um grande e pessimista destaque para os delitos particulares ao mesmo tempo em que silencia a violência estatal, a destruição do Estado de bem-estar social e o arrasamento do meio ambiente. Esse é um ponto importante: toda a violência difusa da sociedade é canalizada e atribuída ao determinado grupo humano vulnerável e estereotipado que comete os crimes desconcertantes transmitidos no noticiário. Este grupo é tratado como a fonte única de todos os riscos sociais e se converte em verdadeiro bode expiatório - conceito este muito bem explorado por René Girard. Ele define que "bode expiatório designa simultaneamente a inocência das vítimas, a polarização coletiva que se efetua contra elas e a finalidade coletiva dessa polarização."39

Em explicação mais nítida, Girard afirma que é comum na experiência humana, seja na história propriamente dita, em textos ou na mitologia, que determinados grupos sejam tidos como responsáveis pelas desgraças públicas provocadoras de terror e de desestabilização cultural. Esta culpabilização se vale de acusações de que estes grupos cometeram crimes, reais ou não, que vão de encontro com os fundamentos da sociedade. Na realidade, importam menos os crimes e mais os sujeitos que o cometeram $^{40}$. Tais indivíduos, vistos como diabólicos, são então perseguidos pela multidão no intuito de que sua eliminação faça desaparecer toda a confusão social e restabelecer uma vida ordenada.

A total irracionalidade desse "esquema transcultural de violência coletiva" ${ }^{41}$ esboçado por René é sempre ressaltada pelo próprio. Apesar da flagrante ausência de razoabilidade, aponta que a causalidade mágica - a atribuir toda a confusão social a uma figura estereotipada e fraca - é aceita por diminuir a angústia e as frustrações coletivas geradas pelos flagelos sociais. Afinal, a resposta a todos os males não precisa passar pelo

\footnotetext{
${ }^{39}$ GIRARD, René. O bode expiatório. São Paulo: Paulus, 2004. P. 55.

${ }^{40}$ Conforme Ibid. P. 26, as vítimas de perseguição em geral podem ser uma minoria, grupos mal integrados ou seres só simplesmente distintos, que historicamente sofrem com preconceito religioso ou cultural ou com reações de ódio, e, ainda, sujeitos com enfermidades em geral, doenças, loucura, bem como aqueles que se distanciam do status social mais comum.

${ }^{41}$ Ibid. P. 29.
} 
reinvento da sociedade ou pelo reconhecimento do papel pessoal de cada um no resultado danoso. A simples eliminação de um grupo proporcionada pela união do coletivo contra os perseguidos é suficiente para acabar com os problemas sociais na ilusão persecutória.

Ora, as características do discurso criminológico da mídia permitem identificar uma separação absoluta na sociedade entre as pessoas decentes aquelas que não cometem crimes e por isso não aparecem negativamente na TV - e uma massa de criminosos feios e desajustados identificada pelo estereótipo. Estes seres diferentes e maus

incomodam, impedem que se durma com portas e janelas abertas, perturbam as férias, ameaçam as crianças, sujam por todos os lados e, por isso, devem ser separados da sociedade, para deixar-nos viver tranquilos, sem medos, para resolver nossos problemas. ${ }^{42}$

Da mesma forma como ocorre na tese de Girard, alastra-se um verdadeiro pânico contra os fatos tipificados como infrações penais, principalmente se cometidos pela camada da sociedade conhecida por delinquir de forma ofensiva, e pede-se por uma repressão rápida, exemplar e duradoura dos seus autores.

Pela aparente grandeza da situação, o campo midiático não se satisfaz com a marginalização social em prisões, mas impõe o verdadeiro aniquilamento destes seres por ser uma reposta mais eficiente às confusões que causam. Neste grande surto persecutório somente a exclusão definitiva ou a medida mais drástica possível garante que a boa sociedade fique protegida.

De tal modo, a imprensa propaga nada menos que um pensamento extremamente semelhante às teses de higiene social defendidas em tempos obscuros da história e da academia. Tanto é assim que as mortes decorrentes de intervenções policiais são lamentadas pela mídia apenas se há certeza da inocência do cadáver. Do contrário, admitem tratar-se de um resultado natural do poder punitivo, como se em guerra estivéssemos, ainda

\footnotetext{
${ }^{42}$ ZAFFARONI, Eugenio Raul. A questão criminal. Rio de Janeiro: Revan, 2013. P. 197.
} 
mais considerando que o falecimento decorre do fato de a vítima escolher pelo seu livre arbítrio ser bandido ${ }^{43}$.

Ao longo da história, mulheres - consideradas bruxas -, judeus e estrangeiros assumiram o papel de bodes expiatórios e foram tratados como inimigos pelo sistema punitivo. Hoje, a influência drástica das matérias jornalísticas - com a atenção exagerada que concede aos crimes e com a dramatização aterrorizante que promove - determina que certos políticos em menor medida e jovens, negros e pobres em gigantesca frequência sejam considerados sujeitos nocivos à sociedade brasileira.

A irracionalidade da perseguição coletiva que foi apontada por Girard e que se percebe no senso comum acerca da questão criminal é reforçada por duas outras características do campo jornalístico - a descontinuidade e a anti-intelectualidade do discurso -, o que se passa a abordar.

O mundo midiático apresenta diariamente nas notícias

uma sucessão sem pé nem cabeça de acontecimentos sem proporção justapostos pelos acasos da coincidência cronológica, um tremor de terra na Turquia e a apresentação de um plano de restrições orçamentárias, uma vitória esportiva e um processo sensacionalista ${ }^{44}$.

Os fatos concretos que são divulgados comumente seguem toda a lógica da concorrência e do sucesso comercial revelada por Bordieu. Neste contexto, em que se quer alcançar o mais extenso público possível, observando a prática dos pares, é comum que a contextualização seja plenamente desprezada. Afinal, todo dia há uma boa quantidade de novos furos a serem revelados que ocupam o espaço de qualquer abordagem ampla e histórica do ocorrido na presente data e nas anteriores.

Não há lugar - ou há pequeníssimo lugar - para a discussão e a compreensão dos fatos da sociedade como a violência difusa. Sobra espaço para as notícias de casos concretos que não se explica e muito menos se

\footnotetext{
${ }^{43}$ Ibid. P. 200.

${ }^{44}$ BOURDIEU, Pierre. Sobre a televisão. Rio de Janeiro, Zahar, 1997. P. 139.
} 
soluciona. Dentro desta lógica de dar voz a certos conteúdos e ocultar outros, o certo é que os meios de comunicação social praticamente não disponibilizam nenhuma informação que sirva de base para entender o fenômeno criminal como um todo. Com isso, tem-se a construção de um "contexto de ameaças incompreensível e inquietante do qual é preciso antes de tudo se retirar e se proteger." 45

O aspecto "des-historicizado e des-historicizante" 46 do discurso promovido pela grande mídia é somado a sua contrariedade ao pensamento abstrato na direção de um ideário pouco ou nada racional sobre a delinquência.

Apesar do anti-intelectualismo do campo jornalístico ser uma constatação forte, Bordieu a explica. De acordo com o sociólogo, o fato extraordinário que é objeto de desejo da mídia deve ser preferencialmente acompanhado por um caráter total ou parcialmente inédito. Em outras palavras, a notícia que o jornalismo busca é um acontecimento que fuja ao cotidiano e que não tenha sido revelado por nenhum concorrente ou que, pelo menos, o fato já publicado por outro seja acompanhado da divulgação de qualquer nova circunstância. A urgência pauta a comunicação midiática neste cenário de pressão para ser o primeiro a descobrir uma quantidade elevada de furos. Além disso, a grande diversidade de temas que se encaixam no referido furo, como política, esporte, economia, segurança pública, entre outros, demanda que os jornalistas falem sobre todos estes assuntos. A partir daí entende-se que o "pensamento pensante" 47 resta prejudicado no campo jornalístico.

Isto porque a verdadeira reflexão demanda o desenvolvimento de teses, a exposição de razões, a manifestação de contrarrazões e a conclusão do raciocínio. Tudo isso requer tempo e conhecimento. Do contrário, está a

\footnotetext{
${ }^{45}$ Ibid. P. 141.

${ }^{46}$ Ibid. P. 140.

${ }^{47}$ Ibid. P. 41.
} 
se afirmar, sem qualquer demonstração, teorias simplistas, comumente aceitas ou até mesmo ideias que não se entende e não se tenta entender.

Toda a rapidez e variedade que é característica quase que elementar dos programas de televisão com altos índices de audiência termina justamente por propagar essas "ideias feitas" 48 marcadas pela banalidade e por serem compartilhadas pelo emissor e receptor. Estas mensagens comuns mantêm intactas formas de ver e de pensar o mundo e são totalmente contrárias ao pensamento que subverte a ordem simbólica dominante. Deste cenário não escapa a questão criminal, ainda mais por ser objeto massivo de notícias homogêneas, como já apontado.

Uma visão fundamentalmente acrítica do sistema punitivo decorre do aspecto anti-intelectual da grande mídia, especialmente marcante no âmbito televisivo. A criminologia midiática, no melhor dos desdobramentos, corrobora o que está aí - repressão e controle social - sem criar um ambiente propicio para discutir possíveis soluções para desvios que escapem à penalidade pura e simples. Isto porque as suas teses são apresentadas sem a presença de contra-argumentos ou de constatações empíricas - até porque não sobreviveriam a eles.

$\mathrm{Na}$ pior das consequências, o discurso disseminado pela grande mídia estimula o recrudescimento do sistema punitivo com a promoção de impulsos vingativos explorando o ápice da irracionalidade criada através dos impactos emocionais unidos ao anti-intelectualismo. A ausência de raciocínio cria o ambiente ideal para a consolidação e o empoderamento do poder punitivo. Isto porque ele se lastreia na vingança que, por essência, é um ato irracional, ao passo em que nunca "se pode fazer que o que foi não tenha sido."49

Neste sentido é que é criada uma fé inabalável na pena e uma certeza da criminalização provedora de acordo com as reflexões do professor Nilo

\footnotetext{
${ }^{48}$ Ibid. P. 41.

${ }^{49}$ ZAFFARONI, Eugenio Raul. A questão criminal. Rio de Janeiro: Revan, 2013. P. 253
} 
Batista. A pena é propagada como o método por excelência de resolução de conflitos e a criminalização é divulgada como ferramenta que resolve os problemas da sociedade ${ }^{50}$. A crença que se desenvolve nos aparatos penais torna-se óbvia de tal maneira que é naturalizada, afinal, desde sempre, é o que todos falam, é o que se verifica na televisão e é o que se vê no dia-adia. Parece que não há outra alternativa e nunca houve. Além disso, a pena chega mesmo a ser sagrada, eis que se mantém independentemente de demonstração técnica.

Por outro lado, é possível que alguém se lembre das participações frequentes de especialistas em sede jornalística e conteste a afirmativa de que a grande mídia menospreza o raciocínio efetivo. No entanto, esses profissionais da área criminal não contribuem muito para elevar a qualidade do debate.

A uma porque os convidados são em geral os mesmos, notadamente aqueles que concordam com o ponto de vista do órgão midiático ou que ao menos não ousam enfrentá-lo com vigor. Nas palavras de Bordieu, esses profissionais "são pessoas que se pode convidar, sabe-se que serão conciliadoras, que não vão criar dificuldades, causar embaraços e, além disso, falam abundantemente, sem problemas." ${ }^{21}$

A duas porque todos os especialistas convocados estão expostos aos mais diversos limites como o tempo disponível para a fala, as intervenções dos apresentadores, a linguagem que empregam e que deveriam empregar, bem como a edição dos programas que não são transmitidos ao vivo. ${ }^{52}$ Neste contexto, mesmo os participantes que querem qualificar a discussão televisiva têm dificuldades, eis que sujeitos a uma série de restrições à transmissão livre e inteligível de ideias. Afinal, a urgência prejudica o desenvolvimento de ideias, as perguntas que orientam as participações

\footnotetext{
${ }^{50}$ BATISTA, Nilo. Mídia e sistema penal no capitalismo tardio. Biblioteca on-line de ciências de comunicação, 2003. Disponível em: <http://www.bocc.ubi.pt/pag/batista-nilo-midia-sistemapenal.pdf>. Acesso em: 01/08/2019. P. 5-4.

${ }^{51}$ BOURDIEU, Pierre. Sobre a televisão. Rio de Janeiro, Zahar, 1997. P. 50.

52 Ibid. 42-50.
} 
muitas vezes são impertinentes, as palavras usadas não raramente são inadequadas para a compreensão de todos e eventuais ideias disfuncionais ao viés midiático podem ser cortadas.

A três porque, no Brasil e em outros países do hemisfério sul, promotores, juízes, peritos e policiais são chamados a comparecer nos jornais e na televisão para responder questões que apenas os criminólogos estudam, conforme revelado por Zaffaroni. ${ }^{53}$ Além de debater aquilo que sabem, estes especialistas são instados a falar sobre as causas do delito, o valor simbólico da pena, o aumento da criminalidade, entre outras perguntas próprias ao conhecimento dos criminólogos. Neste momento, o profissional convocado acaba por repetir e confirmar o discurso da criminologia midiática, eis que é o único que conhece e que é tido como óbvio.

Desta forma, a participação de especialistas contribui para manter uma análise da questão criminal não apenas com forte apelo emotivo e pouca tecnicidade, mas também com aparente respaldo científico. A roupagem técnica torna o pensamento midiático ainda mais crível e favorece o seu sucesso no campo social.

A par dos oito aspectos da criminologia midiática revelados até o momento, junto de suas justificativas conjunturais e de seus efeitos nocivos a uma sociedade justa e pacífica, é preciso agora identificar sua base de sustentação de maior relevância. $\mathrm{O}$ pensamento de autoritário controle populacional, bem como de higiene social que é amplamente divulgado como se bom fosse não subsistiria se não interessasse a alguém.

Neste ponto se insere a mais relevante causa da repercussão criminal na imprensa, qual seja, a visível funcionalidade do discurso midiático sobre a questão criminal para a classe social dominante. É claro que o ideário punitivo propagado pela imprensa de modo tão enfático condiz em grande parte com os interesses das categorias mais favorecidas da sociedade, até

${ }^{53}$ ZAFFARONI, Eugenio Raul. A questão criminal. Rio de Janeiro: Revan, 2013. P. 219-220. 
porque elas integram o patrocínio dos canais midiáticos ou o próprio domínio societário desses canais ${ }^{54}$.

Partindo de um pressuposto foucaultiano ${ }^{55}$, depreende-se que o volumoso alarde conferido ao crime na grande mídia se justifica em grande parte pela tamanha insignificância em termos de disputa de poder que caracteriza os delitos comuns. Nas palavras do filósofo, desde o momento em que a penalidade da prisão e a vigilância do controle policial tornaram a ilegalidade popular política e economicamente inofensiva, as classes mais favorecidas expõem e festejam a delinquência. Sabiamente ocultam a opressão que é imposta pelo Estado por meio da execução da pena enquanto revelam apenas a violência empregada pelo aterrorizante infrator. Deste modo, não abrem margem para o desenvolvimento de empatia pelo criminoso ou de sentimento de injustiça com relação ao tratamento que the é conferido, mas reforçam o apoio total à punição do delinquente desumanizado ${ }^{56}$.

Observe-se bem. Não é que determinado grupo social deva ser apontado como culpado pela disseminação deste pensamento nos grandes meios de comunicação. Na verdade, entender por uma concepção conspiratória segundo a qual certo setor social maneja, de forma prévia e harmônica, todo o aparato de punição seletiva equivale a uma redução confortante, porém falaciosa. ${ }^{57}$ Pierre Bordieu, com grande acerto, observa "muito regularmente, que as grandes escolhas sociais não são feitas por ninguém" 58 , mas antes correspondem a tendências gerais que se mantém pelo benefício trazido aos donos do poder político e econômico.

\footnotetext{
${ }^{54}$ Para mais informações sobre os agentes econômicos por trás da emissora de televisão vide BOURDIEU, Pierre. Op. cit. P. 20.

${ }^{55}$ FOUCAULT, Michel. Vigiar e punir: nascimento da prisão. $42^{\mathrm{a}}$ ed.. Rio de Janeiro: Vozes, 2014. P. 272-279.

${ }^{56}$ Ibid. 68-69.

${ }^{57}$ ZAFFARONI, Eugenio Raul et al. Direito Penal Brasileiro: primeiro volume - Teoria Geral do Direito Penal. $4^{a}$ ed.. Rio de Janeiro: Revan, 2011. P. 48.

${ }^{58}$ BOURDIEU, Pierre. Sobre a televisão. Rio de Janeiro, Zahar, 1997. P. 75.
} 
Importa perceber que a criminologia midiática se mostra aparentemente vantajosa para os segmentos sociais abonados, porque, na maioria das vezes, estes não são atingidos pelo sistema punitivo, mas protegidos por ele. Além disso, a mensagem transmitida é funcional para o controle social, principalmente dos excluídos e das classes médias. ${ }^{59} \mathrm{~A}$ classe média se conforta com o pensamento midiático, eis que demanda a edição de normas para a melhora de sua situação, mas não sabe quais. $\mathrm{O}$ referido vazio é preenchido pela orientação da grande mídia como se a punição de criminosos resolvesse seus problemas. Por outro lado, os excluídos se perdem em rupturas e contradições internas em razão desse mesmo setor social prover os criminalizados (que são perseguidos pelo sistema penal), os vitimizados (que pedem por maior repressão aos seus pares) e os policizados (que perseguem os primeiros).

Em resumo, foi visto que, principalmente em razão da funcionalidade à classe dominante, a grande mídia se debruça sobre a questão criminal com enorme frequência e similar perspectiva. Em razão de toda sua notoriedade, os principais meios de comunicação estabelecem o seu discurso sobre o sistema punitivo basicamente como o único que atinge todo o campo social. Este alcance quase que exclusivo implica na construção de obviedades a partir do pensamento homogêneo da imprensa que confere destaque a certos fatos enquanto oculta outros. Importante ressaltar que a mídia escolhe explorar casos criminais oficiais e individualizados, abrindo margem para uma discriminação dos criminalizados e para um forte apelo a impulsos emotivos. Além disso, deliberadamente desprestigia a reflexão crítica enquanto abusa do medo e da vingança no trato do delito.

Na conjuntura midiática única, óbvia, acrítica e apelativa, a fé na solução penal torna-se intocável. O imaginário coletivo entende como verdade que a pena é o método por excelência de resolução de conflitos e

${ }^{59}$ ZAFFARONI, Eugenio. $O$ inimigo no direito penal. $3^{\text {a }}$ ed.. Rio de Janeiro: Revan, 2007. P. 72 73. 
que a criminalização é um meio formidável de condicionar comportamentos humanos. Afinal, nada que contradiga tais entendimentos é divulgado na imprensa.

Restou sedimentado também que o discurso midiático abusa de uma perspectiva des-historicizada e anti-intelectual a implicar na incompreensão do fenômeno da violência e na catalisação de todo o mal do mundo em figuras facilmente identificadas como problemáticas. A culpabilização de grupos humanos subalternizados por toda a confusão difusa é aceita pela sensação de conforto trazida ao campo social - embora não esteja calcada em qualquer resquício de racionalidade, antes em preconceito infundado.

Respostas autoritárias e simplórias, que vão desde a duradoura detenção até o verdadeiro aniquilamento, são comumente obtidas em desfavor dos infratores e endossadas pelos jornalistas. Enquanto isso, o pensamento midiático ganha um perverso respaldo científico decorrente da participação humilde e restrita de especialistas.

Em síntese ainda mais apertada, pode-se falar - partindo de uma definição de Zaffaroni ${ }^{60}$ - que a mídia opera massivamente com a subinformação ou a desinformação em convergência com um conjunto de preconceitos e crenças desfavoráveis a certos segmentos da sociedade no que se refere a condutas criminosas. Suas mensagens, explícitas e implícitas, compartilham de uma teoria de defesa-social próxima do positivismo criminológico racista $^{61}$. Isto porque identificam criminosos como diferentes das outras pessoas, sobretudo pela sua alegada periculosidade, e pedem pela sua exclusão do convívio com a boa e legítima sociedade.

Retomando o conceito de Rubens Casara, os meios de comunicação são agências do sistema penal porque fazem parte dele, engrandecendo-o.

\footnotetext{
${ }^{60}$ ZAFFARONI, Eugenio Raul. A questão criminal. Rio de Janeiro: Revan, 2013. P. 194.

${ }^{61}$ BATISTA, Nilo. Mídia e sistema penal no capitalismo tardio. Biblioteca on-line de ciências de comunicação, 2003. Disponível em: < http://www.bocc.ubi.pt/pag/batista-nilo-midia-sistemapenal.pd f>. Acesso em: 01/08/2019. P. 2.
} 
No que se refere à grande mídia, a veiculação promovida de fatos criminosos implica em cega naturalização e irrestrita legitimação do poder punitivo junto ao campo social. Não poderia ser diferente, eis que a imprensa aterroriza a sociedade com fenômenos violentos inexplicáveis que parecem remediáveis apenas com a extinção, ou, ao menos, com a marginalização dos desajustados. Nas palavras do próprio magistrado, os meios de comunicação de massa "constroem a imagem da 'boa justiça' associada à repressão e uso da força em detrimento do conhecimento e das práticas restaurativas" 62 .

É certo que os veículos comunicacionais vêm sofrendo mudanças com avanços tecnológicos que cada vez mais condicionam e condicionarão o compartilhamento de informações. Nesta conjuntura, é preciso acrescer à análise do discurso criminológico da mídia as novas formas de circulação de notícias e as alterações introduzidas nas plataformas tradicionais. Antes disso, é importante frisar que toda a reflexão esboçada até aqui não deve ser excluída ou mesmo deixada de lado pelo impacto do meio digital na comunicação de massa. Afinal, o problemático discurso da televisão e dos jornais impressos acerca da questão criminal está presente hoje e se estabeleceu há muitas décadas, sendo certo que seus efeitos sobre o campo social brasileiro são produzidos pelo menos desde o boom televisivo da segunda metade do século XX. Partindo deste pressuposto, a reflexão sobre a criminologia midiática deve considerar principalmente a mencionada informação da grande mídia tradicional e também a influência da internet e dos softwares sobre a comunicação - o que se passa a descrever agora.

\subsection{Os impactos das novas tecnologias e das fake news}

\footnotetext{
${ }^{62}$ CASARA, Rubens R R. Processo penal do espetáculo: e outros ensaios. $2^{\mathrm{a}}$ ed.. Florianópolis: Tirant lo Blanch, 2018. P. 61.
} 
Zaffaroni entende que a mídia opera constantemente com a construção de uma realidade favorável à perseguição de certos grupos humanos tidos como causadores de toda confusão social em razão dos crimes que alegadamente cometem. De acordo com o professor, a criminologia midiática se mantém intacta quanto a esta característica discriminatória variando apenas a tecnologia comunicacional que emprega - “desde o púlpito e a praça até a TV e a comunicação eletrônica"63.

Esta afirmação pode parecer estranha em uma primeira análise do avanço propiciado principalmente pela popularização da internet. Afinal, esta tecnologia de interação se diferencia de todas as anteriores, sobretudo porque potencializa trocas interpessoais verdadeiramente democráticas. Desde o mais poderoso até o mais insignificante ator social, todo o usuário da internet pode compartilhar suas ideias e produzir conteúdo enquanto se armazena um sem-número de dados informacionais e intelectuais acessíveis por qualquer navegante. Em razão destas circunstâncias, teóricos otimistas com relação à internet idealizavam que o debate geral sobre questões públicas e privadas poderia ser aprimorado com o avanço tecnológico mencionado ${ }^{64}$. Sinalizavam que a internet daria voz a todos diferentemente do que faziam as mídias tradicionais monopolizadoras das informações e dos discursos. No entanto, o ideal de que ninguém controlaria este espaço não se concretizou. "Cibercéticos" já colocavam em xeque o potencial democrático da internet ${ }^{65}$ em temores que de certa forma se verificaram no desenvolvimento desta era tecnológica.

Mesmo sabendo que os avanços da tecnologia são constantes, assim como suas mudanças, é importante abordar como o ambiente digital se manifesta hoje. Endossando a visão de Zaffaroni, o presente trabalho passa a demonstrar como a internet contribui para a ininterrupção do apoio irracional ao poder punitivo trabalhado pela grande mídia. Para tanto,

\footnotetext{
${ }^{63}$ ZAFFARONI, Eugenio Raul. A questão criminal. Rio de Janeiro: Revan, 2013. P. 194.

${ }^{64}$ MAGRANI, Eduardo. Democracia conectada: a internet como ferramenta de engajamento político-democrático. Curitiba: Juruá, 2014. P. 57-60.

${ }^{65}$ Ibid. P. 101.
} 
inicialmente se analisa a referida era digital e depois se elucida as suas implicações para o sistema penal em particular.

A primeira característica a se destacar é o fluxo imensurável de informações promovido pela internet. Os mais diversos conteúdos circulam em sites, blogs, redes sociais e plataformas de busca. É uma infinidade de informações, discursos e pontos de vista disponíveis no cosmo da internet que vai desde a diversão de caráter particular até a ciência de interesse público. Contudo, não é possível que este universo informacional seja percebido pelo usuário em sua integralidade. Na verdade, apenas uma parte do conteúdo é apreendida pelos navegantes.

Não é raro que as grandes corporações midiáticas que monopolizam a televisão e o jornalismo impresso se beneficiem desta sobrecarga de conteúdo. Há tempos que as mídias tradicionais se remodelaram para participar ativamente da esfera online e se destacam neste espaço por serem conhecidas e por deterem certo grau de confiabilidade entre o público. Percebe-se que, muitas vezes, as informações das grandes mídias são replicadas em blogs e em postagens do Facebook, Instagram e Twitter, de forma que a diversificação do conteúdo que é de fato acessado na internet não é necessariamente uma regra.

Por outro lado, o surgimento da internet provocou certa degradação na qualidade do produto jornalístico. Primeiro porque esta plataforma diversificada de conteúdo não deixou de resultar em diminuição da venda de jornais e em enfraquecimento da audiência de programas de TV. Com isso, os órgãos midiáticos se tornaram mais dependentes de apoio político e econômico a fim de sobreviverem no mercado ${ }^{66}$. Segundo porque os jornalistas precisaram se reinventar para que acompanhassem as novidades tecnológicas. Seu cotidiano foi substancialmente modificado pelas

\footnotetext{
${ }^{66}$ É o que assevera, por exemplo, o antigo diretor do jornal espanhol El Mundo, David Jiménez, em CARVALHO, Catarina. "A tendência natural do poder é controlar a imprensa", diz jornalista espanhol. Folha de S. Paulo, 17 ago. 2019. Disponível em: < https://www1.folha.uol.com.br/poder/2019/08/a-tendencia-natural-do-poder-e-controlar-aimprensa-diz-jornalista-espanhol.shtml >. Acesso em 05/09/2019.
} 
exigências de diversificar o modo de disponibilização de seus conteúdos, de se especializar no manejo de ferramentas digitais e de publicar notícias a qualquer momento e no menor espaço de tempo possível ${ }^{67}$. Assim, em um ambiente caracterizado por uma quantidade de informações inumerável e inacessível em sua totalidade, as mídias tradicionais fragilizadas se destacam.

Além disso, o conteúdo que se afeiçoa aos interesses de cada usuário, independentemente da fonte, domina seus acessos. A liberdade que é dada aos navegantes de escolha das informações a que têm alcance permite que desfrutem da era digital como plataforma de conhecimento e evolução, como mero dispositivo de consumo de uma cultura empobrecida ou como algo que se insere entre estes dois extremos.

Importante notar que a seleção do conteúdo a ser visualizado está a cargo do usuário e também de algoritmos pouco conhecidos. Diariamente os provedores de conteúdo intervêm naquilo que se encontra disponível ou que é anunciado para seus navegantes. Fotos de amigos próximos, notícias do governante admirado e músicas do estilo musical mais escutado são preferencialmente disponibilizadas para os usuários a fim de que disponham da navegação mais satisfatória possível. A partir da coleta de dados pessoais, provedores que dominam a internet ${ }^{68}$ como Facebook, Youtube e Google entregam aos seus usuários plataformas personalizadas que o estimulam a permanecer o máximo de tempo possível online $e^{69}$.

A implicação desta dupla filtragem reside na criação de bolhas na esfera digital - segunda característica a merecer enfoque. A seleção de informações que agradem ou que importem ao usuário - seja pelo próprio,

\footnotetext{
${ }^{67}$ MAGRANI, Eduardo. Op. cit. P. 82.

68 MARINONI, Bruno. Desinformação: ameaça ao direito à comunicação muito além das fake news. São Paulo: Intervozes - Coletivo Brasil de Comunicação Social, jul. 2019. Disponível em: < https://intervozes.org.br/publicacoes/desinformacao-ameaca-ao-direito-a-comunicacao-muitoalem-das-fake-news/ > . Acesso em 05/09/2019. P. 17.

${ }^{69}$ BRANCO, Sérgio. Fake News e os Caminhos para Fora da Bolha. Revista Interesse Nacional, 2017. Disponível em: < https://itsrio.org/wp-content/uploads/2017/08/sergio-fakenews.pdf > Acesso em 20/08/19. P. 52.
} 
seja por terceiro - modela a realidade virtual em que está inserido a gosto do freguês. Em outras palavras, a partir dos anúncios que propositadamente recebe e das escolhas que faz de obter informações de determinadas páginas, o navegante mergulha em um espaço online que se coaduna com sua própria visão de mundo.

É certo que o ambiente narcisista ${ }^{70}$ criado, apesar de satisfazer o usuário e o provedor de conteúdo, frequentemente exclui opiniões contrárias ao navegante ${ }^{71}$. Por conseguinte, a bolha virtual propicia a união de pessoas que se assemelham em gostos, pensamentos e outros interesses, enquanto distancia grupos de críticos e dos que pensam de forma diferente. Neste sentido, o fechamento de grupos de interação em que há circulação e reafirmação de pensamentos pré-concebidos pode polarizar a sociedade em extremos. Além disso, o mundo digital caracterizado pela restrição customizada do conteúdo reduz a pluralidade de informações transmitida ao usuário. Consequentemente, o navegante restrito ao universo eletrônico homogêneo acessa uma perspectiva simplificada de mundo ou uma visão reduzida da realidade e, por isso, torna-se potencialmente manipulável.

A filtragem de conteúdo e a inserção do usuário em uma bolha de seus próprios interesses não seria possível sem a disponibilização, a venda $e$ o uso dos seus dados pessoais - terceira característica do desenvolvimento da internet e de tecnologias adjacentes. Nunca antes na história foi tão fácil acessar informações que identificassem serem humanos e revelassem seus gostos e seus traços comportamentais. As inúmeras possibilidades de controlar os usuários que daí decorrem foram rapidamente percebidas pelo poder econômico e depois pelo político, de modo que, não

\footnotetext{
${ }^{70}$ Ibid. P. 52.

${ }^{71}$ Ibid. P. 53.
} 
por acaso, os bancos de dados são considerados o bem de maior valor dos tempos atuais ${ }^{72}$.

Aproveitando-se da exposição dos usuários, do desconhecimento geral sobre o funcionamento das tecnologias e da escassez de leis que regulassem a privacidade em âmbito digital, atores econômicos direcionavam sua publicidade e elevavam os valores cobrados por seus produtos a depender do navegante a fim de alavancar seu sucesso mercadológico. Por outro lado, entes públicos valeram-se de vulnerabilidades tecnológicas e da vasta quantidade de informações em meio digital para espionar cidadãos nacionais ou estrangeiros, empresas ou chefes de Estado. O big data também serviu para que atores políticos traçassem perfis dos usuários e influenciassem suas escolhas políticas por meio da promoção de conteúdo mobilizador. Tudo isso sem que o usuário concordasse com a ingerência em seus dados ou sequer soubesse de tal vigilância.

Hoje, diplomas legais como o Regulamento Geral sobre a Proteção de Dados da Europa e a Lei Geral de Proteção de Dados Pessoais do Brasil visam minimizar os efeitos da exploração indevida de bancos de dados. No entanto, tais normas foram editadas após destroços serem deixados pela espionagem norte-americana revelada por Edward $\operatorname{Snowden}^{73}$ e pelas práticas de propaganda política não convencional da Cambridge Analytica $^{74}$. No caso brasileiro, a referida lei entra em vigor apenas em 15 de agosto de 2020.

\footnotetext{
${ }^{72}$ Cf. The World's Most Valuable Resource is no Longer Oil, but Data. The Guardian, 06 mai. 2017. Disponível em: < https://www.economist.com/leaders/2017/05/06/the-worlds-mostvaluable-resource-is-no-longer-oil-but-data >. Acesso em 02/09/2019.

73 Para mais informações vide MAGRANI, Eduardo. Democracia conectada: a internet como ferramenta de engajamento político-democrático. Curitiba: Juruá, 2014. P. 158-162.

74 Para mais informações vide ROSENBERG, Matthew; CONFESSORE, Nicholas; CADWALLADR, Carole. How Trump Consultants Exploited the Facebook Data of Millions. The New York Times, 18 mar. 2018. Disponível em: < https://www.nytimes.com/2018/03/17/us/politics/cambridge-analytica-trump-campaign.html >. Acesso em 02/09/2019.
} 
No ambiente digital preocupa, ainda, uma quarta característica consistente na fácil disseminação de fake news.

A transmissão de notícias inautênticas não é algo exatamente novo. No campo do crime e da violência, jornalistas reconhecem que a criação de histórias era prática comum e antiga nos meios de comunicação tradicionais, como revela o jornalista Luarlindo Ernesto em entrevista:

"As histórias inventadas eram muitas. [...] Desde o monstro da praia de Ramos,
inventado por um repórter do Última Hora, até o caso mais famoso, do Mão
Branca [...], um matador de bandidos que nunca existiu. Os repórteres
encontravam um cadáver e colocavam uma cartolina com a frase: 'Este não mata
mais'. E depois davam a notícia. Isso era nos anos 70. Depois do Mão Branca,
teve o China, o King Fu, todo mundo foi nessa onda."75 No entanto, hoje a divulgação massiva de informações adulteradas atinge seu ápice em termos de quantidade, qualidade e implicações, aproveitando-se do terreno fértil ${ }^{76}$ para tanto que é a internet. A multiplicação de comunicadores e o relevante alcance do conteúdo que circula online ajudam a explicar a magnitude atingida por fake news nos dias atuais. A comunicação por trás de avatares também o faz, eis que estimula a publicação irrefletida de conteúdo online, incluindo informações com aspecto duvidoso provenientes de fontes desconhecidas ${ }^{77}$. Outras possibilidades aventadas pela tecnologia como a automação do envio de mensagens - por meio de Bots e Ciborgues - e o direcionamento de conteúdo a depender da personalidade de cada usuário - traçada pela análise de dados comercializados - esclarecem, ainda, a dimensão das fakes news na contemporaneidade, uma vez que contribuem para o sucesso de seus efeitos. Por fim, pode-se apontar que a narrativa construída pela internet acostuma todos a um mundo que se conforma aos próprios

\footnotetext{
${ }^{75}$ RAMOS, Silvia; PAIVA, Anabela. Mídia e violência: tendências na cobertura de criminalidade e segurança no Brasil. Rio de Janeiro: IUPERJ, 2007. P. 16.

${ }^{76}$ DELMAZO, Caroline; VALENTE, Jonas C.L.. Fake news nas redes sociais online: propagação e reações à desinformação em busca de cliques. Media \& Jornalismo, Lisboa, v. 18, n. 32, p. 155169, abr. 2018. Disponível em < http://www.scielo.mec.pt/pdf/mj/v18n32/v18n32a12.pdf $>$. Acesso em 04/09/ 2019. P. 157.

${ }^{77}$ BRANCO, Sérgio. Fake News e os Caminhos para Fora da Bolha. Revista Interesse Nacional, 2017. Disponível em: < https://itsrio.org/wp-content/uploads/2017/08/sergio-fakenews.pdf > Acesso em 20/08/19. P. 57.
} 
interesses. Assim, informações que desafiem pontos de vista não são exatamente benquistas pelos indivíduos. Nesta conjuntura, muitas vezes a confirmação das próprias convicções torna-se mais importante que a autenticidade do dado consumido e compartilhado.

Como um fenômeno reconfigurado e complexo, fake news não é algo simples de se definir. A UNESCO ${ }^{78}$ tenta fazê-lo abrangendo três formas, a saber, (i) campanhas de desinformação, sendo esta conceituada como informação que é falsa e deliberadamente criada para prejudicar uma pessoa, um grupo social, uma organização ou um país; (ii) informação equivocada, entendida como informação que é falsa, mas não foi criada com a intenção de causar algum dano; e (iii) informação maldosa, a significar informação baseada na realidade, usada para causar danos a uma pessoa, grupo social, organização ou país. Percebe-se que fake news são muito mais do que meros boatos. Na verdade, são um feito capaz de desvirtuar a percepção da realidade e impactar posições sobre a vida e escolhas políticas de cada indivíduo.

Por tudo o que comporta, a disseminação de fake news foi elevada à tática dentro de disputas de poder ${ }^{79}$. Não se trata de uma prática ingênua, mas planejada de acordo com finalidades políticas e/ou lucrativas. No tocante à interferência política, fala-se muito que o uso alarmante de fake news impulsionou a eleição de Donald Trump ${ }^{80}$ nos Estados Unidos, bem como a de Jair Bolsonaro ${ }^{8182}$ no Brasil. Por outro lado, no que se refere ao

78 Cf. UNESCO. Desinformação (fake news). Genebra: UNESCO, 2017. Disponível em: <http://www.unesco.org/new/pt/brasilia/communication-and-information/freedom-ofexpression/media-development/disinformation/>. Acesso em 02/09/2019.

79 Inclusive, integrante do PSL, afirmou saber que fake news foram usadas na campanha presidencial de Bolsonaro, ocorrida em 2018, como parte de um "jogo sujo". Cf. ALEXANDRE Frota comenta uso de notícias falsas durante campanha eleitoral. TV Cultura. Disponível em: <https://tvcultura.com.br/videos/70626_alexandre-frota-comenta-uso-de-noticias-falsas-durantecampanha-eleitoral.html>. Acesso em 04/09/2019.

${ }^{80} \mathrm{Cf}$. PARKINSON, Hannah Jane. Click and elect: how fake news helped Donald Trump win a real election. The Guardian, 14 nov. 2016. Disponível em: < https://www.theguardian.com/commentisfree/2016/nov/14/fake-news-donald-trump-election-altright-social-media-tech-companies >. Acesso em 04/09/2019.

${ }^{81}$ Cf. PASQUINI, Patrícia. $90 \%$ dos eleitores de Bolsonaro acreditaram em fake news, diz estudo. Folha de S. Paulo, 2 nov. 2018. Disponível em: < 
potencial de lucro das fake news, em fevereiro de 2017, a Folha de S. Paulo publicou uma reportagem sobre os altos montantes recebidos com o compartilhamento e o clique de notícias falsas, afirmando que

profissionais do mercado publicitário [...] estimaram que os anúncios do site rendam de $\mathrm{R} \$ 100$ mil a $\mathrm{R} \$ 150$ mil por mês, dos quais até $50 \%$ ficariam com o intermediário e o restante com o dono do site. ${ }^{83}$

Para atingir os objetivos mencionados, evidente que fakes news não podem passar despercebidas. É preciso que estimulem engajamento, gerem cliques e provoquem compartilhamentos. Deste modo, as referidas notícias são comumente caracterizadas por desenvolver um senso de novidade e de urgência, bem como por estimular indignação, medo ou raiva no seu receptor. Embora não seja possível afirmar que fake news sejam usadas exclusivamente por determinada corrente política ou filosófica, é certo que tais características contribuem para o crescimento de um conservadorismo perigoso $^{84}$ - afinal, a intolerância, a desinformação e o apego às emoções em detrimento da razão são típicos de governos totalitários.

Enquanto as campanhas de desinformação se desenvolvem, algumas formas de contê-las estão sendo formuladas enquanto outras começam a ser implementadas. Relevante notar que propostas aclamadas como a criação

\footnotetext{
https://www1.folha.uol.com.br/poder/2018/11/90-dos-eleitores-de-bolsonaro-acreditaram-emfake-news-diz-estudo.shtml >. Acesso em 04/09/2019.

82 Importante estudo desenvolvido pelo ITS sobre o uso de ferramentas de automação para o impulsionamento digital de campanhas políticas nas eleições brasileiras de 2018 concluiu que existem fortes indícios de ação automatizada em múltiplos grupos de WhatsApp e que há um alto grau de interconexão, registrado pelo número elevado de administradores e membros que os grupos compartilham entre si. Vide MACHADO, Caio; KONOPACKI, Marco. Poder Computacional: Automação no uso do WhatsApp nas Eleições. Rio de Janeiro: Instituto de Tecnologia e Sociedade do Rio de Janeiro, 2018. Disponível em: < https://itsrio.org/pt/publicacoes/automacao-eleicoes/ >. Acesso em 05/09/2019.

A proliferação de notícias falsas nestes grupos foi percebida por pesquisa da BBC Brasil. Vide GRAGNANI, Juliana. Um Brasil dividido e movido a notícias falsas: uma semana dentro de 272 grupos políticos no WhatsApp. BBC Brasil, 5 out. 2018. Disponível em: < https://www.bbc.com/portuguese/brasil-45666742 >. Acesso em 05/09/2019.

${ }_{83}$ Vide VICTOR, Fabio. Como funciona a engrenagem das notícias falsas no Brasil. Folha de S. Paulo, 19 fev. 2017. Disponível em: < https://www1.folha.uol.com.br/ilustrissima/2017/02/1859808-como-funciona-a-engrenagem-dasnoticias-falsas-no-brasil.shtml >. Acesso em 02/09/2019.

${ }^{84}$ MARINONI, Bruno. Desinformação: ameaça ao direito à comunicação muito além das fake news. São Paulo: Intervozes - Coletivo Brasil de Comunicação Social, jul. 2019. Disponível em: < https://intervozes.org.br/publicacoes/desinformacao-ameaca-ao-direito-a-comunicacao-muitoalem-das-fake-news/ >. Acesso em 05/09/2019. P. 11-12.
} 
de agências de checagem - não raro atreladas às mídias tradicionais ou às plataformas dos gigantes digitais - e a criminalização da divulgação de notícias adulteradas se revelam ameaçadoras aos direitos fundamentais. Afinal, constatar a inautenticidade da descrição de fatos diretamente verificáveis apresenta relativa tranquilidade, o que não se repete em todos os casos de possíveis fake news ${ }^{85}$. Nas hipóteses mais complexas envolvendo notícias com opinião ou análise de fatos, o atestado de desinformação dependerá da concepção de verdade dos checadores, assim como de seus valores e ideologias ${ }^{86}$. Além disso, a decisão do que é a verdade entregue aos poderosos da mídia, do mercado ou do Estado é capaz de ser usada para silenciar pensamentos críticos e vozes dissonantes ${ }^{87}$. Portanto, o maior desafio relativo ao enfrentamento das fake news reside em enfraquecê-las sem violar a liberdade de expressão.

$\mathrm{O}$ ambiente online deve ser compreendido também por uma quinta e última característica que ganhará destaque, qual seja, a superficialidade do acesso à informação. A Imprensa da Universidade de Coimbra divulgou um apanhado de pesquisas que revelam a não rara distância existente entre a partilha de links e a sua leitura em si. De acordo com o artigo publicado:

Estudo divulgado em junho de 2016 pela Universidade de Columbia e o Instituto Nacional Francês mostra que 59\% dos links partilhados em redes sociais não chegam a ser clicados de facto (Dewey, 2016). Dessa forma, uma manchete atraente - que normalmente fica explícita na URL do link - já seria suficiente para garantir engajamento. Mesmo quando os links são clicados, poucos leitores vão passar dos primeiros parágrafos [...]. Estudo do Nielsen Norman Group divulgado em 2013 mostrou que $81 \%$ dos leitores voltam os olhos - o que não significa necessariamente que estão, de fato, a ler - para o primeiro parágrafo de um texto na internet, enquanto $71 \%$ chegam ao segundo. São $63 \%$ os que olham para o terceiro parágrafo, e apenas $32 \%$ voltam os olhos para o quarto. (Nielsen, 2013). O estudo foi feito com base no eye-tracking, conjunto de tecnologias que regista os movimentos oculares de um indivíduo determinando em que áreas fixa a sua atenção, por quanto tempo e que ordem segue na sua exploração visual (Barreto, 2012). Outro desafio ainda se coloca na qualidade da leitura. "A não ser que se preste atenção especial ao que está lendo, os artigos ficam

\footnotetext{
${ }^{85}$ Ibid. P. 39.

${ }^{86}$ Ibid. P. 39.

${ }^{87}$ Ibid. P. 35.
} 
descontextualizados em relação às suas fontes e fatos se misturam livremente com ficção" (Chen, Conroy \& Rubin, 2015b, tradução própria). ${ }^{88}$

Este cenário é propiciado pela urgência que caracteriza a contemporaneidade, bem como pela falta de paciência dos usuários para mergulhar em assuntos profundos. É nítido que o costume - implementado pela televisão e continuado pela internet - de digerir mensagens rápidas por meio de vídeos, fotos e manchetes curtas não é facilmente abandonado. A implicação desta característica, por sua vez, consiste no agravamento da desorientação promovida pelo meio digital, seja pela fácil crença em fake news, seja pela ausência de compreensão, total ou parcial, das informações consumidas.

Em suma, foi visto que o desenvolvimento das novas tecnologias comunicacionais permite que os usuários das redes se fechem em informações e grupos que os interessem. Desta forma, antes de intensificar trocas e debates sobre questões públicas e particulares, a internet parece reforçar as visões de mundo e polarizar a sociedade.

Observou-se, ainda, que a exposição dos usuários combinada à intervenção dissimulada do espaço digital pelo poder econômico e político possibilita o condicionamento dos navegantes para que adquiram certo produto ou serviço ou para que assumam determinada posição políticofilosófica.

A desinformação no meio digital foi também um elemento da era tecnológica apontado, notadamente pela fácil circulação de fake news e pela superficialidade do consumo de informações por parte significativa dos usuários. Neste cenário, ganha espaço a exploração de dados rasos, bem como de temores e indignações, seja pelo elevado e rápido consumo que proporcionam, seja pela sua distância da reflexão crítica e racional que facilita o almejado controle dos indivíduos.

\footnotetext{
${ }^{88}$ DELMAZO, Caroline; VALENTE, Jonas C.L.. Fake news nas redes sociais online: propagação e reações à desinformação em busca de cliques. Media \& Jornalismo, Lisboa, v. 18, n. 32, p. 155169, abr. 2018. Disponível em < http://www.scielo.mec.pt/pdf/mj/v18n32/v18n32a12.pdf >. Acesso em 04/09/ 2019. P. 158.
} 
Importa, agora, salientar que a questão criminal não sai imune desta conjuntura da comunicação eletrônica.

O fechamento de conexões impede um significativo alcance de pessoas e pensamentos diferentes - como alvos e críticos do sistema penal , que deveria ser o verdadeiro trunfo dos novos meios de comunicação em contraposição aos antigos. Os diferenciados se perdem na sobrecarga de informação e acabam por falar para eles mesmos. Não apenas se isolam, mas os opositores do poder punitivo são também incompreendidos pelos simpatizantes da punição - que constituem a maioria dos indivíduos, afundada na lógica óbvia da grande mídia acerca do delito. A distância da diversidade prejudica debates profundos, assim como alimenta intolerâncias contra o diferente, bem vistas pelo poder de punir.

Além disso, a influência - sempre presente - do poder político e econômico na esfera digital tende a afastar aquilo que os prejudique como ataques à técnica funcional à classe dominante em que consiste o poder punitivo. A manipulação de conteúdo e comportamento que os poderosos operam online deixa preferencialmente intocável a crítica ao sistema punitivo.

A desinformação acalorada também impacta o discurso criminológico dos meios de comunicação social. Primeiro porque a desorientação favorece o funcionamento do sistema penal, na medida em que quanto menos se informa sobre a justiça criminal, mais se acredita nos seus fins revelados. O campo social crê que a função da prática punitiva seja proteger a sociedade de inimigos e desajustados. Segundo porque o envolvimento de matéria sentimental estimula radicalismos e respostas repulsivas que legitimam a resolução de conflitos por meio da punição. $\mathrm{O}$ apelo emocional engrandece o poder punitivo na medida em que a pena que 
este aplica se baseia na vingança que, por essência, se revela um ato irracional contra o que se passou no tempo. ${ }^{89}$

Isto tudo indica que a era digital vem agravando a manutenção da ordem vigente de apoio ao poder de punir, nos moldes iniciados pela televisão. Embora detenha enorme potencial, o campo eletrônico não tem permitido romper com a visão hegemônica das mídias tradicionais acerca da questão criminal tão repetidas no imaginário social, principalmente pela influência que também recebe dos poderes político e econômico.

Singelos exemplos podem reforçar a análise ora elaborada. Há diversos casos de disseminação de fake news envolvendo o suposto cometimento de crimes que resultaram em linchamentos reais ou virtuais perpetrados pelo campo social..$^{90}$ Além disso, uma recente pesquisa em páginas de bairros do Rio de Janeiro existentes no Facebook ${ }^{91}$ mostra que os problemas de segurança pública detém foco importante, embora não majoritário, nestas plataformas. Identificou-se a relação destas páginas com a mídia tradicional -

por um lado alguns grandes jornais passaram a basear parte de seu noticiário em conteúdos provenientes dessas páginas; por outro, elas constituem espaços de compartilhamento e difusão de notícias publicadas por veículos de mídia tradicionais. ${ }^{92}$

\footnotetext{
${ }^{89}$ ZAFFARONI, Eugenio Raul. A questão criminal. Rio de Janeiro: Revan, 2013. P. 192 e 257.

${ }^{90}$ Sérgio Branco nos recorda de três casos. Segundo ele, "em maio de 2014, uma dona de casa de 33 anos foi espancada até a morte por vários moradores da cidade do Guarujá, onde vivia, após boatos espalhados pelo Facebook de que ela sequestrava crianças para utilizá-las em rituais de bruxaria. Segundo o marido da vítima, a página Guarujá Alerta publicou equivocadamente uma foto da mulher como se fosse ela a suspeita pelo sequestro das crianças. Algumas pessoas acreditaram que se tratava mesmo dela e então a amarraram, arrastaram e espancaram violentamente, o que acabou por acarretar sua morte. Infelizmente, este não é o único caso em que notícias falsas levaram a consequências reais e muito graves. Em 2016, um serralheiro morador da Baixada Fluminense foi identificado como estuprador de crianças e passou a ser ameaçado de morte. Neste ano [2017], uma multidão tentou linchar um casal em Araruama, Estado do Rio de Janeiro, após boato de sequestro de criança divulgado no WhatsApp. Outros exemplos poderiam ser citados. " Cf. BRANCO, Sérgio. Fake News e os Caminhos para Fora da Bolha. Revista Interesse Nacional, 2017. Disponível em: <https://itsrio.org/wp-content/uploads/2017/08/sergiofakenews.pdf $>$ Acesso em 20/08/19. P. 59-60.

${ }^{91}$ NUNES, Pablo. Crime e polícia no \#RiodeJaneiro: Relatos em páginas do Facebook. Boletim Segurança e Cidadania, n. 24, outubro de 2017. Disponível em: < https://www.ucamcesec.com.br/boletim/crime-e-policia-no-riodejaneiro-relatos-em-paginas-dofacebook/>. Acesso em 12/09/19.

92 Ibid. P. 27.
} 
Ademais, concluiu-se que, dentro da temática de segurança e violência, uma análise factual detém notoriedade, especialmente sobre a dinâmica do tráfico de drogas e das facções criminosas, as ações policiais, bem como a identificação de crimes e de seus autores. Nas palavras do pesquisador Pablo Nunes,

A circulação de informações nesse tipo de rede, se, por um lado tem função autoprotetiva, carrega, por outro, o risco do vigilantismo e do justiçamento, além de poder ser um veículo de reprodução e potencialização de estereótipos e preconceitos. ${ }^{93}$

Importante destacar que o intocável apoio ao poder punitivo propagado pela comunicação encontra especial êxito no Brasil. Isto porque a cultura brasileira é fortemente marcada pelo autoritarismo, sendo influenciada por toda uma história de pequenas pausas democráticas em um enredo de Estado de exceção.

Os trezentos anos de escravidão, por si só, permitiram "a naturalização de uma visão de mundo que aceita a hierarquização entre os seres humanos, a utilização de pessoas para fins políticos e econômicos, o descarte de vidas e a negociação envolvendo os valores"94. Além disso, o período de colonização europeia, os diversos golpes de Estado, as recentes ditaduras do Estado Novo varguista e do movimento militar, bem como a eleição constante de sujeitos moralistas, fãs de torturadores e saudosos da ordem ditatorial, delineiam uma tradição opressiva que se tem no país.

Desta forma, é certo que o brasileiro se acostumou com o "uso da força em detrimento do conhecimento como forma de solucionar os mais diversos problemas sociais" $" 95$ em uma mentalidade autoritária que se alia totalmente à legitimação do poder de punir.

Enfim, a perda da sociedade em uma cultura violenta e vingativa é estimulada pela comunicação social, seja a partir dos isolamentos e

\footnotetext{
${ }^{93}$ Ibid. P. 28.

${ }^{94}$ CASARA Rubens R R. Processo penal do espetáculo: e outros ensaios. $2^{\text {a }}$ ed.. Florianópolis: Tirant lo Blanch, 2018. P. 19.

95 Ibid. P. 19.
} 
desinformação constatados online, seja a partir da transmissão de "inimigos mortos" ou de "soldados caídos" 96 na televisão. A combinação dos efeitos da mídia tradicional com as novas tecnologias favorece o poder de punir e esvazia o Estado Democrático de Direito como sistema de garantia dos direitos humanos.

Importante notar que a quantidade de desdobramentos desta criminologia midiática é vasta, mesmo quando restrita à matéria de garantias jurídicas. É possível citar a sua interferência na inviolabilidade da honra e imagem das pessoas, assim como na garantia da ampla defesa aos acusados em geral. Dentro de todo este espectro, o presente trabalho trata da presunção de inocência, explicando, em primeiro lugar, o seu significado e sua importância, em segundo lugar, o motivo da escolha e, em terceiro, o impacto que sofre. Tudo isto com base, principalmente, nos ensinamentos de Maurício Zanoide de Moraes constantes da obra Presunção de inocência no processo penal brasileiro: uma análise de sua estrutura normativa para a elaboração legislativa e para a decisão judicial.

${ }^{96}$ ZAFFARONI, Eugenio Raul et al. Direito Penal Brasileiro: primeiro volume - Teoria Geral do Direito Penal. $4^{a}$ ed.. Rio de Janeiro: Revan, 2011. P. 58. 


\section{PRESUNÇÃO DE INOCÊNCIA: UMA GARANTIA MÍNIMA DE SEGURANÇA E DE LIBERDADE EM RISCO}

Todo o indivíduo é sujeito de direitos em razão da elevada condição que lhe é inerente. Por outro lado, qualquer intervenção penal é sempre uma imposição de dor e sofrimento à pessoa, notadamente pela restrição da liberdade de ir e vir e de outros direitos fundamentais que é de sua natureza. Estes conceitos básicos sustentam a limitação do poder punitivo implementada por, dentre outras garantias, a presunção de inocência.

Definida, em linhas gerais, como a garantia de que toda pessoa acusada de um delito tem direito a que se presuma sua inocência até a eventualidade de se comprovar sua culpa por meios legais, a presunção de inocência representa uma escolha juspolítica ${ }^{97}$. Mais do que uma mera formalidade processual ou uma restrita presunção judicial ${ }^{98}$, o estado de inocência se revela como a opção de rejeitar uma intervenção punitiva na sociedade que seja totalmente autoritária ou pouco criterios $\mathrm{a}^{99}$. Isto porque admite a imposição de sanções apenas na hipótese de haver a certeza jurídica da violação de uma lei penal. É, também, a escolha de condicionar a persecução criminal a valores de garantia e de igualdade ${ }^{100}$, em razão de possibilitar uma defesa do imputado afastada de preconceitos e de desequilíbrios com o acusador. É a eleição, ainda, da tutela da imunidade de todo e qualquer inocente, mesmo que ao custo da impunidade de algum culpado $^{101}$, uma vez que cria óbices

\footnotetext{
${ }^{97}$ MORAES, Maurício Zanoide de. Presunção de inocência no processo penal brasileiro: análise de sua estrutura normativa para a elaboração legislativa e para a decisão judicial. Rio de Janeiro: Lumen Juris, 2010. P. 355.

98 CARVAlHO, L. G. Grandinetti Castanho de. Processo penal e constituição: Princípios constitucionais do processo penal. $5^{\mathrm{a}}$ ed.. Rio de Janeiro: Editora Lumen Juris, 2009. P. 162.

${ }^{99}$ MORAES, Maurício Zanoide de. Op. cit. P. 355.

${ }^{100}$ Ibid. P. 355.

${ }^{101}$ FERRAJOLI, Luigi. Direito e razão: teoria do garantismo penal. $3^{\mathrm{a}}$ ed.. rev. São Paulo: Editora Revista dos Tribunais, 2002. P. 441.
} 
para a intervenção punitiva que não esteja fundada no juízo pacífico de convicção quanto à responsabilidade por um ilícito penal.

Ao longo da história, a presença desta norma jurídica esteve sempre vinculada a Estados tendentes a garantir maior igualdade e liberdade aos seus cidadãos. Por outro lado, sua ausência se atrelou a aparatos estatais que produziram significativa violência contra sua população ${ }^{102}$. Hoje, esta opção político-ideológica de empoderamento do indivíduo frente aos mecanismos de violência do Estado se encontra assentada em declarações e convenções internacionais de direitos humanos.

A Declaração Universal dos Direitos do Homem e do Cidadão ${ }^{103}$ e a Declaração Universal dos Direitos Humanos ${ }^{104}$ afirmam o ideal de consagrar a referida garantia. Além disso, o Pacto Internacional de Direitos Civis e Políticos ${ }^{105}$ e a Convenção Americana sobre Direitos Humanos ${ }^{106}$ obrigam os estados signatários a proteger e garantir a presunção de inocência.

Muito em razão desta tutela internacional, no mundo moderno, não há Estado Democrático de Direito que não estabeleça a presunção de inocência como um dos preceitos basilares do seu sistema processual penal $^{107}$. O Estado brasileiro, especificamente, assume o compromisso de condicionar todo o seu sistema penal a esta norma em razão de se submeter aos tratados mencionados e de elencar a presunção de inocência como cláusula pétrea da sua ordem constitucional.

\footnotetext{
${ }^{102}$ Cf. discorrido no capítulo um deste trabalho.

${ }^{103}$ Declaração Universal dos Direitos do Homem: Art. $9^{\circ}$. Todo acusado é considerado inocente até ser declarado culpado e, se julgar indispensável prendê-lo, todo o rigor desnecessário à guarda da sua pessoa deverá ser severamente reprimido pela lei.

${ }^{104}$ Declaração Universal dos Direitos Humanos: Artigo 11.1. Todo ser humano acusado de um ato delituoso tem o direito de ser presumido inocente até que a sua culpabilidade tenha sido provada de acordo com a lei, em julgamento público no qual lhe tenham sido asseguradas todas as garantias necessárias à sua defesa.

${ }^{105}$ Pacto Internacional de Direitos Civis e Políticos: Art. 14.2. Toda pessoa acusada de um delito terá direito a que se presuma sua inocência enquanto não for legalmente comprovada sua culpa. ${ }^{106}$ Convenção Americana sobre Direitos Humanos: Art. 8.2. Toda pessoa acusada de delito tem direito a que se presuma sua inocência enquanto não se comprove legalmente sua culpa. [...]

${ }^{107}$ MORAES, Maurício Zanoide de. Presunção de inocência no processo penal brasileiro: análise de sua estrutura normativa para a elaboração legislativa e para a decisão judicial. Rio de Janeiro: Lumen Juris, 2010. P. 347.
} 
Terminado o regime da ditadura militar, a Constituição da República, pela primeira vez em um diploma constitucional do Brasil, previu expressamente o direito à presunção de inocência no seu artigo $5^{\circ}$, inciso LVII, dentro do título "Dos Direitos e Garantias Fundamentais" e sob o capítulo "Dos Direitos e Deveres Individuais e Coletivos", usando os seguintes termos: "ninguém será considerado culpado até o trânsito em julgado de sentença penal condenatória." Além disso, a Carta de 1988 garantiu que este direito não possa ser abolido nem mesmo por uma emenda constitucional, nos termos do seu artigo $60, \S 4^{\circ}$, inciso IV. Mais do que isso, tornou inadmissível a modificação ou o encaminhamento à remoção, ainda que remoto, ${ }^{108}$ da presunção de inocência, ao asseverar que "não será objeto de deliberação a proposta de emenda tendente a abolir os direitos e garantias individuais".

Como o direito humano e direito fundamental que é, o estado de inocência é universal, irrevogável, complementar e interdependente. Isto é dizer que a situação de inocente se estende a todo ser humano, em uma tendência contínua de expansão, sem que seja possível afastá-la dos demais direitos humanos de todas as dimensões ${ }^{109}$.

Todo o protagonismo da presunção de inocência - vista como regrachave do processo penal ${ }^{110}$ - desemboca em diversos desdobramentos deste direito, notadamente em princípios e regras jurídicas. Tais aplicações podem ser analisadas em três partes que correspondem ao âmbito de proteção do estado de inocência. Zanoide de Moraes proclama que tais partes podem ser percebidas por meio das seguintes perguntas:

\footnotetext{
${ }^{108}$ Nesse sentido, SILVA, José Afonso da. Curso de direito constitucional positivo. $39^{\mathrm{a}}$ ed.., ver. e atual. São Paulo: Malheiros, 2016. P. 69., afirmando sobre o art. 60, §4º da Constituição Federal de 1988 que "A vedação atinge a pretensão de modificar qualquer elemento conceitual da Federação, ou do voto direito, ou indiretamente restringir a liberdade religiosa, ou de comunicação ou outro direito e garantia fundamental; basta que a proposta se encaminhe ainda que remotamente, 'tenda' (emendas tendentes, diz o texto) para a sua abolição."

${ }^{109}$ MORAES, Maurício Zanoide de. Op. cit. P. 207-211.

110 CARVAlHO, L. G. Grandinetti Castanho de. Processo penal e constituição: Princípios constitucionais do processo penal. $5^{\text {a }}$ ed.. Rio de Janeiro: Editora Lumen Juris, 2009. P. 163.
} 
a) a efetivação da presunção de inocência no processo penal depende, de modo mais direto, de quais níveis estatais? b) quais os bens da vida protegidos por ela? c) qual a sua extensão subjetiva e objetiva no âmbito processual penal? ${ }^{111}$

Tais indagações passam a ser respondidas à luz do ordenamento jurídico brasileiro.

A pergunta "a" que orienta o âmbito de proteção da presunção de inocência busca determinar qual ação estatal é necessária para a realização do direito mencionado no ordenamento jurídico. ${ }^{112}$ Apesar de ter aplicação imediata $^{113}$, o estado de inocência precisa da atuação do Legislativo para a criação de leis que o conformem e do Judiciário para interpretar as referidas leis e aplicá-las ao caso concreto. Significados da presunção de inocência que se inserem neste contexto são o in dubio pro reo e o favor rei. $\mathrm{O}$ in dubio pro reo será versado mais a frente quando da análise da segunda pergunta. Já o favor rei pode ser logo definido como uma escolha valorativa que influencia tanto o legislador quanto o julgador no sentido de ideais como igualdade, dignidade e liberdade. ${ }^{114}$ A presunção de inocência manifestada como favor rei deve orientar a elaboração legislativa, no sentido de observar e garantir o referido direito, e a atividade interpretativa do dispositivo legal, no sentido mais favorável ao imputado. ${ }^{115}$

A pergunta " $b$ " pretende indicar os bens da vida tutelados pela norma em comento de forma direta e indireta. ${ }^{116}$ Para respondê-la, recorre-se às aplicações que a presunção de inocência contempla que podem ser agrupadas em dois grupos - dimensão de prova e dimensão de tratamento.

A primeira dimensão inclui o impacto do estado de inocência sobre a produção probatória - quem deve provar, por meio de que prova e o que

\footnotetext{
${ }^{111}$ MORAES, Maurício Zanoide de. Op. cit. P. 362.

112 Ibid. P. 363.

113 A Constituição da República Federativa do Brasil estabelece o seguinte: Art. $5^{\circ}$, $\S 1^{\circ}$ As normas definidoras dos direitos e garantias fundamentais têm aplicação imediata.

${ }^{114}$ MORAES, Maurício Zanoide de. Op. cit. 365.

115 Ibid. P. 369.

${ }^{116}$ Ibid. P. 424.
} 
deve ser provado ${ }^{117}$-, bem como sobre a apreciação da prova no sistema criminal.

Presumir uma parte inocente significa atribuir todo o encargo probatório à outra. É intuitivo que o estado de inocência do acusado o desincumbe do ônus de comprovar a inveracidade da imputação que sobre ele possa recair. Por outro lado, a presunção de inocência implica em atribuir ao acusador o dever de demonstrar a tese de culpabilidade não pressuposta pela Constituição ${ }^{118}$ e pelas normas cogentes de direito internacional. Cumpre ressaltar que a obrigação de colher a integralidade da prova da culpa na ocorrência do ilícito penal não é excessiva para a acusação. Isto porque ela é sempre composta por um poderoso aparato - o Ministério Público e a Polícia Judiciária no Brasil - que funciona "para obter a prova necessária para desconstituir a presunção constitucional de inocência" ${ }^{119}$. Percebe-se que o contrário - a imposição de que o acusado demonstre sua inocência diante de uma acusação - é que seria demasiadamente custoso e potencialmente injusto.

Ainda, o devido processo legal deve ser respeitado para que, de forma legítima, o direito à presunção de inocência possa eventualmente ser elidido no campo probatório ${ }^{120}$. Observando os ditames da legalidade, o órgão acusatório deve demonstrar tecnicamente a prática de um fato típico, ilícito e culpável por meio da prova da materialidade e da autoria delituosa ${ }^{121}$. Não é possível que meras suspeitas ou informações colhidas sem o contraditório e a ampla defesa sejam aptas a fulminar a elevada presunção de inocência. Tampouco a confissão obtida por meio de tortura ou o elemento encontrado no cumprimento de busca domiciliar sem autorização judicial podem impor a condenação a uma pessoa que tem sua inocência presumida. Afinal, não é qualquer meio ou elemento capaz de

\footnotetext{
117 Ibid. P. 462.

118 Ibid. P. 462.

119 CARVAlHO, L. G. Grandinetti Castanho de. Processo penal e constituição: Princípios constitucionais do processo penal. $5^{\mathrm{a}}$ ed.. Rio de Janeiro: Editora Lumen Juris, 2009. P. 173.

${ }^{120}$ MORAES, Maurício Zanoide de. Op. cit. P. 463.

${ }^{121}$ Ibid. P. 464.
} 
reverter a presunção de inocência. Do contrário, estar-se-ia a esvaziar o caro significado deste direito.

A presunção de inocência como norma probatória é, também, formada pelo sentido de que a dúvida na demonstração do pleito acusatório favorece o imputado ${ }^{122}$. A convicção judicial é influenciada pelo estado de inocência na medida em que o pedido condenatório deve ser suficiente para demonstrar, de forma pacífica, a culpa do acusado na ocorrência do crime. Havendo uma dúvida razoável no tocante à tese da acusação, é certo que esta parte não terá cumprido o seu dever de reverter a presunção de inocência e, por isso, deve ter sua pretensão rejeitada.

Destaque-se que a absolvição por força do in dubio pro reo, esculpida como regra específica no artigo 386, VII, do Código de Processo Penal, não é o único desdobramento do estado de inocência na apreciação probatória. Na verdade, também o recebimento da denúncia, o decreto de prisão preventiva, o oferecimento de transação penal e outras decisões tendentes a restringir os direitos do acusado em função de um suposto crime devem estar acompanhadas de provas suficientes para excepcionar a presunção de inocência ${ }^{123}$. Em todos estes pronunciamentos judiciais, é correto afirmar que a motivação das decisões é fundamental para que se possa aferir a observância das formas legítimas de superação da presunção de inocência ${ }^{124}$.

A segunda dimensão do estado de inocência abrange a forma como imputados devem ser tratados. O dever de tratamento como inocente impede a imposição de qualquer efeito condenatório ao acusado antes do estabelecimento definitivo da culpa na ocorrência do crime imputado. Isto significa obstar qualquer medida típica de um juízo de culpa na esfera penal - como sanção, restrição de direito ou estigmatização - enquanto a

${ }^{122}$ FERRAJOLI, Luigi. Direito e razão: teoria do garantismo penal. $3^{\text {a }}$ ed.. rev. São Paulo: Editora Revista dos Tribunais, 2002. P. 442.

${ }^{123}$ MORAES, Maurício Zanoide de. Op. cit. P. 468.

${ }^{124}$ Ibid. P. 476. 
inocência do acusado é presumida. Tal dimensão do estado de inocência impossibilita, por exemplo, a execução antecipada de pena, a suspensão de direitos políticos decorrente de condenação recorrível e a inclusão do acusado no rol dos culpados na pendência de recurso da sua condenação. Ana Lúcia Menezes Vieira contribui para a definição e exemplificação deste âmbito da presunção de inocência, explicando que, como regra de tratamento, o estado de inocência

Significa que durante o desenvolvimento do processo o tratamento do acusado deve ser isento de situações que propiciem a antecipação ou um juízo de culpabilidade, por exemplo, o uso de algemas quando desnecessário, a posição degradante e inferior no banco dos réus, palavras e gestos humilhantes que o tornem diminuído além do necessário imposto pela condição de investigado ou processado. ${ }^{125}$

Frise-se que a presunção de inocência como regra de tratamento obriga, sobretudo, a preservação do estado de liberdade do imputado. Enquanto ela não for totalmente elidida pela concretização da culpa, não é possível impor pena em forma de prisão ou em qualquer outra modalidade de restrição da liberdade do acusado. Consequentemente, a prisão para averiguação e o encarceramento antecipatório de pena são exemplos de medidas autoritárias terminantemente vedadas pela presunção de inocência.

Em caráter excepcional, é certo que há instrumentos de privação da liberdade antes da formação definitiva da culpa admitidos pelo processo penal ${ }^{126}$. No entanto, para que esta garantia não reste inócua, tal espécie de prisão é aceita tão somente em último caso e em razão de fundamentos rígidos que não se lastreiem no crime supostamente cometido. No Brasil, a presunção de inocência garante que a prisão-processual seja limitada a possibilidades estritas e excepcionais ${ }^{127}$ e que a prisão-pena decorra tão-

\footnotetext{
125 VIEIRA, Ana Lúcia Menezes. Processo penal e mídia. São Paulo: Editora Revista dos Tribunais, 2003. P. 172.

${ }^{126}$ Cumpre ressaltar que há uma corrente minoritária, defendida por Ferrajoli, a sustentar que a presunção de inocência torna ilegítimo o encarceramento cautelar. Para mais informações, vide FERRAJOLI, Luigi. Direito e razão: teoria do garantismo penal. $3^{a}$ ed.. rev. São Paulo: Editora Revista dos Tribunais, 2002. P. 445-450.

127 CARVAlHO, L. G. Grandinetti Castanho de. Processo penal e constituição: Princípios constitucionais do processo penal. $5^{\text {a }}$ ed.. Rio de Janeiro: Editora Lumen Juris, 2009. P. 163.
} 
somente da condenação definitiva ${ }^{128}$, conforme se identifica na regra específica do artigo $283^{129}$ do Código de Processo Penal. À luz desta garantia, o ordenamento jurídico brasileiro admite a prisão em flagrante observado o flagrante delito, conforme previsto no artigo $302^{130}$ do Código de Processo Penal, bem como o fim de obstar a prática do crime - e a prisão cautelar - respeitados o fumus comissi delicti e o periculum in libertatis, bem como a finalidade de preservar o processo e a eventual pena ${ }^{131}$. Por outro lado, rejeita a prisão decorrente de decisão recorrível e a vedação abstrata da concessão de liberdade provisória, garantindo "que os efeitos de uma eventual decisão condenatória somente sejam aplicados após o seu trânsito em julgado"132.

Esta dimensão da presunção de inocência implica, também, em minimizar outras intervenções decorrentes do direito penal na vida do imputado. Uma pessoa considerada inocente não pode simplesmente ser submetida a interferências em sua privacidade, situação financeira e honra, eis que estas são restrições típicas de sanções penais. Por isso que medidas como interceptação telefônica, limitação de final de semana e sequestro assecuratório devem ser determinadas de forma restrita. É mister que se pondere a sua imprescindibilidade para o processo penal com o estado de inocência do acusado perante a imputação - sem se esquecer de sua dignidade.

\footnotetext{
${ }^{128}$ A condenação definitiva é aquela que forma uma coisa julgada material. Mais especificamente, a constituição da coisa julgada material se dá "com o conhecimento e a rejeição do recurso extraordinário e do recurso especial, com a sua não-interposição, ou com o julgamento e a rejeição do agravo interposto para o recebimento dos referidos recursos.” Ibid. P. 166.

${ }^{129}$ Código de Processo Penal Brasileiro. Art. 283. Ninguém poderá ser preso senão em flagrante delito ou por ordem escrita e fundamentada da autoridade judiciária competente, em decorrência de sentença condenatória transitada em julgado ou, no curso da investigação ou do processo, em virtude de prisão temporária ou prisão preventiva.

${ }^{130}$ Código de Processo Penal Brasileiro. Art. 302. Considera-se em flagrante delito quem: I - está cometendo a infração penal; II - acaba de cometê-la; III - é perseguido, logo após, pela autoridade, pelo ofendido ou por qualquer pessoa, em situação que faça presumir ser autor da infração; IV - é encontrado, logo depois, com instrumentos, armas, objetos ou papéis que façam presumir ser ele autor da infração.

${ }^{131}$ Ibid. P. 163.

${ }^{132}$ MORAES, Maurício Zanoide de. Presunção de inocência no processo penal brasileiro: análise de sua estrutura normativa para a elaboração legislativa e para a decisão judicial. Rio de Janeiro: Lumen Juris, 2010. P. 427
} 
A pergunta "c" que ajuda a definir o âmbito de proteção do estado de inocência visa determinar quais sujeitos são atingidos e protegidos pelo referido direito, bem como de que ponto e até que ponto do processo penal ele incide. ${ }^{133}$

A extensão subjetiva da presunção de inocência indica, por um lado, que todo indivíduo deve respeitar e cumprir este direito, seja agente público, seja agente privado. ${ }^{134}$ Por outro lado, determina que qualquer pessoa (física ou jurídica) submetida à persecução penal seja contemplada pela presunção de inocência, inclusive sem nenhum espaço para graduação de mais ou menos inocente pelo motivo que seja. ${ }^{135}$ A extensão objetiva, por sua vez, revela que a presunção de inocência se faz presente em todo espaço jurídico alcançado pelo direito processual penal, o que abrange a fase investigativa, a instrutória-judicial, a recursal e a revisional. ${ }^{136}$

Em um resumo destes significados, oportuno é o seguinte ensinamento de Maurício Zanoide de Moraes:

\begin{abstract}
A presunção de inocência, assim como todos seus aspectos e desdobramentos, incluídos aqui o "in dubio pro reo" e o "favor rei", representa um direito que veio atender à igualdade, ao respeito à dignidade da pessoa humana, à liberdade do cidadão e ao devido processo legal porquanto: a) torna a relação jurídica entre imputado e órgãos persecutórios mais equilibrada (garantia à igualdade), impedindo que as manifestações do poder público ultrapassem o necessário para a apuração dos fatos; b) impede, de ordinário, que ao imputado seja dado tratamento de condenado, antes do reconhecimento definitivo de sua culpa (garantia à dignidade da pessoa); c) impõe a necessidade de um processo condizente com todos os padrões constitucionais de justiça para que se proceda à verificação e declaração de culpa do cidadão (garantia de devido processo legal); d) impõe uma decisão menos prejudicial ao imputado sempre que houver dúvida fática ou se possa proceder à mais favorável escolha jurídica, como asseveração do prestígio à dignidade da pessoa humana em toda e qualquer decisão judicial penal. ${ }^{137}$
\end{abstract}

A partir de tais sentidos atribuídos à presunção de inocência, pode-se depreender que a referida norma, nos moldes defendidos por Ferrajoli ${ }^{138}$, se

\footnotetext{
${ }^{133}$ Ibid. P. 481.

134 Ibid. P. 481-482.

135 Ibid. P. 483-490.

136 Ibid. P. 490-491.

${ }^{137}$ Ibid. P. 347.

${ }^{138}$ FERRAJOLI, Luigi. Direito e razão: teoria do garantismo penal. $3^{\mathrm{a}}$ ed.. rev. São Paulo: Editora Revista dos Tribunais, 2002. P. 441.
} 
mostra uma garantia de segurança e de liberdade no âmbito processual penal. Explica-se.

A presunção de inocência trata-se de uma garantia de segurança, eis que permite evitar que penas arbitrárias e outros abusos do poder de punir existam. A referida norma assegura que a intervenção penal não seja exercida de forma irrestrita, mirando qualquer pessoa pelo motivo que for. Afinal, impede a fixação de sanções penais diante de demonstrações insuficientes de culpa, bem como inviabiliza a exigência de esforços descomunais para a comprovação da inocência. Considerando que o poder punitivo é, potencialmente, tão violador dos direitos quanto qualquer crime praticado por particulares - ou até mais -, o estado de inocência representa um instrumento de defesa social contra a ameaçadora repressão penal.

Cuida-se de uma garantia de liberdade, porque impede que o direito de ir e vir dos indivíduos seja limitado por motivos insuficientes antes da definição da sua culpa por um delito. Não é concebível que percepções liminares, sempre mais susceptíveis a incorporar equívocos e preconceitos, submetam os indivíduos, em toda a sua dignidade, a penosas e irreversíveis intervenções em suas vidas. É preciso, também, que mais de uma instância avalie o caso criminal a fim de mitigar as inevitáveis falhas humanas. A partir disso, os sujeitos têm o direito de aguardar em liberdade o deslinde de acusações que sofram até que reste comprovada sua culpa ou confirmada sua inocência.

A presunção de inocência é, ainda, uma garantia de verdade, de acordo com este professor. Isto porque o estado de inocência possibilita um tempo para a apreciação dos fatos com cuidado e parcimônia. Além disso, traz um equilíbrio entre a acusação e o acusado, que, com liberdade de ir e vir e sem o peso de ser tratado como culpado, dispõe de maiores chances de enfrentar o poderoso e equipado órgão acusatório. A maior cautela na prestação jurisdicional e a igualdade entre as partes permitem que a verdade processual seja formada com maior acerto. 
Em razão de tudo o que representa, renomados doutrinadores reconhecem a presunção de inocência com honraria. Luigi Ferrajoli a intitula como conquista da civilidade ${ }^{139}$ e Aury Lopes Jr. defende que o seu nível de observância pode ser um censor da qualidade democrática de um Estado $^{140}$. Maurício Zanoide de Moraes, por sua vez, entende que a norma em comento é eixo estruturante ${ }^{141}$ de um processo penal que, nas palavras de Simone Schreiber, “deixa de ser um mero instrumento de realização da pretensão punitiva do Estado, para se transformar em um instrumento de tutela da liberdade"142.

Cumpre frisar que a presunção de inocência não deixa de ser uma garantia mínima do indivíduo contra os mecanismos violentos do Estado. Isto porque o estado de inocência, como fruto do pensamento liberalburguês, não elimina a imposição da pena no campo social. Na realidade, ele convive com a repressão de Estado, determinando apenas que o maior peso do poder punitivo seja exercido após o término da apreciação judicial quanto à culpa do sujeito na prática de determinada conduta considerada criminosa. Deste modo, é possível dizer que a presunção de inocência, mesmo em todo o seu esplendor, é uma das menores normas que pode existir no sentido de limitar o poder de punir.

A despeito de ser de extrema relevância e de ser mínima perante os interesses do poder punitivo, a presunção de inocência encontra dificuldades para ser incorporada na cultura geral, incluindo a sua esfera jurídica, especialmente no Brasil. Alguns exemplos de contrariedades à presunção de inocência praticadas por atores jurídicos podem ser citados.

\footnotetext{
139 Ibid. P. 450.

${ }^{140}$ LOPES JUNIOR, Aury. Direito Processual Penal. 14a ed.. São Paulo: Saraiva, 2017. P. 95-96.

${ }^{141}$ MORAES, Maurício Zanoide de. Presunção de inocência no processo penal brasileiro: análise de sua estrutura normativa para a elaboração legislativa e para a decisão judicial. Rio de Janeiro: Lumen Juris, 2010. P. 358.

${ }^{142}$ SCHREIBER, Simone. A publicidade opressiva de julgamentos criminais - Uma investigação sobre as consequências e formas de superação da colisão entre a liberdade de expressão e informação e o direito ao julgamento criminal justo, sob a perspectiva da Constituição brasileira de 1988. Rio de Janeiro: Renovar, 2008. P. 189.
} 
Há décadas se desenvolveu na jurisprudência brasileira um suposto princípio aplicado principalmente em decisões referentes à legitimidade da continuação da persecução criminal, qual seja, o in dubio pro societate. Esta invenção - assim denominada por não estar respaldada em qualquer previsão legal ou constitucional - estabelece que a dúvida no recebimento da denúncia, na decisão de pronúncia e no julgamento da revisão criminal deve favorecer a acusação ${ }^{143}$. É certo que estes momentos processuais não exigem a certeza quanto ao crime e a sua autoria, mas demandam o cumprimento de níveis probatórios diferenciados que permitam o prosseguimento legítimo da persecução criminal. Zanoide explica sabiamente que

O imputado, de ordinário, começa na condição de suspeito podendo passar a partir desse ponto para a condição de indiciado, denunciado, acusado e, por fim, condenado. A progressão não é automática, precisa que a carga incriminadora vá legitimando, passo a passo, as mudanças nessas posições jurídicas. Para a suspeita bastam conjecturas, desconfianças, leves opiniões subjetivas a respeito da materialidade e da autoria. Para se passar à condição de indiciado é necessário um pouco mais, são necessários indícios que demonstrem a autoria provável de um crime já tido como demonstrado. Sem esses indícios não há como se passar do primeiro para o segundo estágio. ${ }^{144}$

E por aí vai. De acordo com o in dubio pro societate, a dúvida no preenchimento da carga probatória exigida pelo respectivo momento processual deve levar à continuação da persecução criminal em cumprimento a alegados interesses da sociedade. É certo que este suposto princípio está em total descompasso com a dimensão probatória da presunção de inocência assentada constitucionalmente ${ }^{145}$.

O estado de inocência determina que o órgão de investigação ou de acusação tem de demonstrar qualquer indício favorável à tese que não é pressuposta pela Constituição e pelo direito internacional - a da inocência do imputado. Na contramão, o in dubio pro societate concede um ilógico benefício ao acusador que não cumpre o seu ônus de provar o exigido por

\footnotetext{
${ }^{143}$ MORAES, Maurício Zanoide de. Op. cit. P. 412.

144 Ibid. P. 415.

${ }^{145}$ LOPES JUNIOR, Aury. Direito Processual Penal. 14a ed.. São Paulo: Saraiva, 2017. P. 359.
} 
cada fase processual e aprova a submissão do imputado às agruras de um processo penal pelos mais rasos motivos.

Além disso, este disparate é incompatível com as cargas probatórias definidas pelo estado de inocência, porque tal fidedigna norma não prevê exceções procedimentais ou inversões do ônus probatório ${ }^{146}$. Na verdade, a presunção de inocência não está restrita à condenação ou à fixação da pena, mas percorre todas as etapas da intervenção penal, sabendo que, além das sanções, "a própria existência da persecução é um mal (social, moral, jurídico, econômico, entre outros) que se impõe ao imputado e representa, outrossim, um custo para o Estado." 147

A incompatibilidade do in dubio pro societate com a presunção de inocência é há muito denunciada pela doutrina. Embora encontre algumas

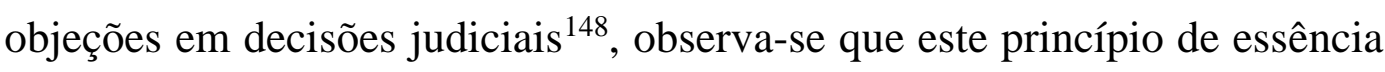
contra legem é majoritariamente aplicado pela jurisprudência do país ${ }^{149}$.

Por outro lado, a presunção de inocência resta violada quando os imputados são tratados como verdadeiros criminosos pelos agentes da lei. É o que se passa com o abuso da imposição de prisões provisórias no Brasil. Embora dados exatos sejam difíceis de serem apontados, notadamente pela precariedade na sua produção, é certo que o número de pessoas presas provisoriamente no país é expressivo.

O Infopen, sistema vinculado ao Departamento Penitenciário Nacional do Ministério da Justiça, publicou relatórios em 2016 e em 2017 a partir de informações prestadas pelas unidades prisionais que indicam,

\footnotetext{
${ }^{146}$ Ibid. P. 361.

${ }^{147}$ MORAES, Maurício Zanoide de. Presunção de inocência no processo penal brasileiro: análise de sua estrutura normativa para a elaboração legislativa e para a decisão judicial. Rio de Janeiro: Lumen Juris, 2010. P. 414.

${ }^{148}$ Cite-se, por exemplo, o STF, ARE 1.067.392, Segunda Turma, Rel. Ministro Gilmar Mendes, Brasília, 26 fev. 2019 e o STJ, REsp 1.689.173 / SANTA CATARINA, Sexta Turma, Rel. Ministro Rogerio Schietti Cruz, Brasília, 21 nov. 2017.

${ }^{149}$ Por exemplo, o STJ, AgRg no HC 466.216 / RIO DE JANEIRO, Quinta Turma, Rel. Ministro Ribeiro Dantas, 10 set. 2019; o STJ, AgRg no AREsp 1464941 / Goiás, Sexta Turma, Rel. Ministro Laurita Vaz, Brasília, 03 set. 2019; e a STF, AO 2275 / RIO GRANDE DO NORTE, Primeira Turma, Rel. Ministro Luiz Fux, Brasília, 23 out. 2018).
} 
respectivamente, um percentual de $40^{150}$ e $33,29 \% \%^{151}$ de presos sem qualquer condenação dentro do sistema penitenciário. Além disso, disponibilizou um gráfico ${ }^{152}$ com a evolução da população carcerária desde o início do século que revela o contínuo crescimento do encarceramento em massa acompanhado pelo aumento do número de presos provisórios no Estado brasileiro. Recentemente, o Banco Nacional de Monitoramento de Prisões - BNMP, de iniciativa do Conselho Nacional de Justiça, produziu um levantamento a partir de dados referentes a mandados de prisão alimentados pelo Poder Judiciário. Esta plataforma revela que, atualmente, $41,64 \%$ da população carcerária é formada por presos sem qualquer condenação e $22,96 \%$ é composto por detentos em execução provisória de pena $^{153}$. Isto totaliza mais de meio milhão de pessoas encarceradas sem uma condenação criminal definitiva ${ }^{154} \mathrm{em}$ um panorama de mais de oitocentas e trinta mil pessoas privadas de liberdade no Brasil.

Nem mesmo a implementação das audiências de custódia em 2015 por força do Pacto São José da Costa Rica ${ }^{155}$, do Pacto Internacional sobre Direitos Civis e Políticos ${ }^{156}$ e da Resolução no $213 / 2015$ do CNJ - foi capaz

\footnotetext{
150 SANTOS, Thandara; ROSA, Marlene Inês da. Levantamento nacional de informações penitenciárias: INFOPEN Atualização - Junho de 2016. Brasília: Ministério da Justiça e Segurança Pública. Departamento Penitenciário Nacional, 2017. Disponível em: < http://depen.gov.br/DEPEN/noticias-1/noticias/infopen-levantamento-nacional-de-informacoespenitenciarias-2016/relatorio_2016_22111.pdf >. Acesso em 03/10/2019. P. 13.

151 MOURA, Marcos Vinicius. Levantamento Nacional de Informações Penitenciárias. Atualização - Junho de 2017. Brasília: Ministério da Justiça e Segurança Pública. Departamento Penitenciário Nacional, 2019. Disponível em: http://depen.gov.br/DEPEN/depen/sisdepen/infopen/relatorios-sinteticos/infopen-jun-2017-rev12072019-0721.pdf > Acesso em 03/10/2019. P. 14. 152 Ibid. P. 15.

$153 \quad$ Disponível em: < https://paineis.cnj.jus.br/QvAJAXZfc/opendoc.htm?document=qvw_1/PainelCNJ.qvw\&host=QVS @ neodimio03\&anonymous=true\&sheet=shBNMPIIMAPA >. Acesso em 03/10/2019.

${ }^{154}$ Importante ressaltar que este número não considera a distinção entre presos que optaram pela execução provisória - a fim de poderem se valer dos direitos contidos na Lei de Execuções Penais - e os presos que foram submetidos à execução provisória da pena em seu desfavor.

${ }^{155}$ Convenção Americana Sobre Direitos Humanos. Art. 7.5: Toda pessoa detida ou retida deve ser conduzida, sem demora, à presença de um juiz ou outra autoridade autorizada pela lei a exercer funções judiciais e tem direito a ser julgada dentro de um prazo razoável ou a ser posta em liberdade, sem prejuízo de que prossiga o processo. Sua liberdade pode ser condicionada a garantias que assegurem o seu comparecimento em juízo.

156 Pacto Internacional Sobre Direitos Civis e Políticos. Art. 9.3: Qualquer pessoa presa ou encarcerada em virtude de infração penal deverá ser conduzida, sem demora, à presença do juiz ou de outra autoridade habilitada por lei a exercer funções judiciais e terá o direito de ser julgada em
} 
de reverter este cenário. A condução de uma pessoa detida a frente de um juiz foi medida vocacionada à apuração da necessidade do acautelamento, bem como à verificação de casos de tortura em abordagem policial que, não obstante a boa intenção, não gerou os efeitos previstos. Um levantamento do Instituto de Defesa do Direito de Defesa - IDDD, feito entre os meses de abril e dezembro de 2018 e em doze cidades do Brasil, revelou que, da amostra de 2.584 decisões consultadas, $57 \%$ consistiam em manutenção do cárcere com o decreto de prisão preventiva. Isto fora os $40 \%$ de determinações de liberdade provisória com a fixação de medidas cautelares diversas do encarceramento. Apenas $1 \%$ resultou em liberdade provisória sem cautelares e $2 \%$ em relaxamento de prisão.

Evidente que este cenário não condiz com a excepcionalidade e as possibilidades restritas de limitação da liberdade sem formação definitiva de culpa impostas pela presunção de inocência. Na verdade, indica a essência de um poder punitivo impaciente exercido há tempos em toda a América Latina, conforme reflete o professor Eugenio Raúl Zaffaroni. Por aqui, há uma tendência ao autoritarismo que desvirtua a lógica do processo penal e implementa uma verdadeira presunção de periculosidade ao arrepio do estado de inocência. Nas palavras do ilustre penalista e criminólogo:

A característica mais destacada do poder punitivo latino-americano atual em relação ao aprisionamento é que a grande maioria - aproximadamente $3 / 4$ - dos presos está submetida a medidas de contenção, porque são processados não condenados. [...] trata-se de um poder punitivo que há muitas décadas preferiu operar mediante a prisão preventiva ou por medida de contenção provisória transformada definitivamente em prática. [...] tudo se converteu em privação de liberdade sem sentença firme, apenas por presunção de periculosidade. ${ }^{157}$

A inelegibilidade de indivíduos condenados em sentença recorrível por determinados crimes é mais um exemplo de ofensa à presunção de inocência constitucionalmente garantida. $\mathrm{Na}$ esteira de uma construção social de criminalização da política e de necessidade de combater, a

prazo razoável ou de ser posta em liberdade. A prisão preventiva de pessoas que aguardam julgamento não deverá constituir a regra geral, mas a soltura poderá estar condicionada a garantias que assegurem o comparecimento da pessoa em questão à audiência, a todos os atos do processo e, se necessário for, para a execução da sentença.

${ }^{157}$ ZAFFARONI, Eugenio. O inimigo no direito penal. $3^{\mathrm{a}}$ ed.. Rio de Janeiro: Revan, 2007. P. 70. 
qualquer custo, os desvios de dinheiro público, a Lei Complementar $\mathrm{n}^{\circ}$ 135/10, popularmente conhecida como Lei da Ficha Limpa, alterou a Lei Complementar $n^{\circ}$ 64/90 para expandir os casos em que pessoas se tornam inelegíveis. De acordo com a Lei de 2010, a condenação por crimes contra a fé pública, o patrimônio público ou privado, o sistema financeiro, entre outros, proferida por órgão colegiado, mesmo que recorrível, impede que o acusado seja eleito para qualquer cargo.

Ora, tal imposição de restrições de direitos que são típicas de sanções penais em momento anterior à formação de um juízo definitivo de culpa fere frontalmente o estado de inocência. Importante ressaltar que a suspensão dos direitos políticos é um efeito sancionatório da condenação transitada em julgado, conforme disposto no artigo 15, III, da Constituição da República. É certo que esta medida, especialmente vinculada ao juízo de culpa no âmbito penal, não cabe a pessoas consideradas inocentes de acusações delituosas e, portanto, sua imposição deve aguardar eventual trânsito em julgado de condenação criminal.

Apesar disso, o Supremo Tribunal Federal, por maioria, julgou constitucional este aspecto da Lei da Ficha Limpa com o reconhecimento expresso de que, para tanto, reduzia a presunção de inocência a fins estritamente penais com o fito de salvaguardar princípios de probidade e moralidade da Administração Pública. Tratou-se, portanto, de uma relativização do direito fundamental ao estado de inocência em prol da observância de normas administrativas. Nos autos da Ação Declaratória de Constitucionalidade 30 e Ação Direta de Inconstitucionalidade 4578, a Corte Suprema elegeu, assumidamente, uma tese que flexibiliza a presunção de inocência, segundo a qual as sanções decorrentes de culpa por um ilícito penal não precisam observar a referida garantia em sua integralidade quando aplicadas na esfera eleitoral-administrativa. 
A verdade é que nem mesmo os efeitos estritamente penais da presunção de inocência são, de fato, garantidos pelo Supremo Tribunal Federal.

A Constituição da República foi promulgada em 1988, mas apenas em 2009 a Corte Suprema admitiu que o seu artigo 5º, inciso LVII, veda a execução da pena antes do trânsito em julgado de sentença penal condenatória. A partir do Habeas Corpus 84.078 / MG, de relatoria do eminente Ministro Eros Grau, foi reconhecido que a Carta de 1988 veda a antecipação dos efeitos da culpa por um ilícito penal e - por ser a culpa pressuposto do crime e da pena - veda por consequência obrigatória o aprisionamento como forma de cumprimento de pena antes do referido marco processual.

Tal entendimento, que contempla a presunção de inocência como assentada em nossa Carta Política, foi revertido em 2016, no bojo do Habeas Corpus 126.292 / SP, quando este Tribunal voltou a julgar constitucional a execução provisória de acórdão penal condenatório proferido em grau de apelação. Mesmo que este precedente não ostentasse efeito vinculante, foi logo replicado por diversos Tribunais do país tornando automática a execução provisória da sentença em matéria penal nas terras brasileiras ${ }^{158}$. Além disso, o entendimento firmado pela decisão foi usado para a elaboração de proposta de $\operatorname{lei}^{159}$ e de emenda constitucional ${ }^{160}$ tendentes a positivar a redução da presunção de inocência, embora isto seja incompatível com nossa ordem constitucional.

\footnotetext{
${ }^{158}$ Como exemplo, é possível citar o Tribunal Regional Federal da $4^{\text {a }}$ Região que editou o seguinte enunciado sumular: Súmula 122. "Encerrada a jurisdição criminal de segundo grau, deve ter início a execução da pena imposta ao réu, independentemente da eventual interposição de recurso especial ou extraordinário."

159 O PL 882/2019, apresentado como parte do denominado "Pacote Anticrime" apresentado pelo Ministro da Justiça e Segurança Pública e ex-juiz, Sergio Moro, tem por objetivo alterar a redação do artigo 283 do Código de Processo Penal para que ganhe os seguintes termos: "Art. 283. Ninguém poderá ser preso senão em flagrante delito ou por ordem escrita e fundamentada da autoridade judiciária competente, em decorrência de prisão cautelar ou em virtude de condenação criminal transitada em julgado ou exarada por órgão colegiado."

${ }^{160}$ A PEC 410/2018 foi proposta em 27/03/2018 com o objetivo de alterar o inciso LVII do art. $5^{\circ}$ da Constituição Federal para prever que "ninguém será considerado culpado até a confirmação de sentença penal condenatória em grau de recurso".
} 
A suposta constitucionalidade da execução da pena sem o trânsito em julgado da respectiva condenação criminal foi reafirmada pelo Supremo Tribunal Federal em diversas oportunidades até serem pautadas as primeiras ações que trataram de discutir a garantia da presunção de inocência em abstrato. Em 07 de novembro de 2019, terminou o julgamento das Ações Declaratórias de Constitucionalidade 43, 44 e 54 em que a apertada maioria do colegiado declarou a constitucionalidade do artigo 283 do Código de Processo Penal, a admitir o encarceramento antes do trânsito em julgado de condenação somente em caso de prisão em flagrante, prisão preventiva ou prisão temporária.

É importante frisar que os fundamentos apresentados pelos Ministros que se mostraram favoráveis à antecipação da pena são, em sua maioria, de ordem diversa da jurídica. A título ilustrativo, lembra-se que eles aduziram que a observância da presunção de inocência até o trânsito em julgado poderia levar à impunidade de criminosos. Outrossim, apresentaram estatísticas para afirmar que a maioria das decisões levadas ao Superior Tribunal de Justiça e ao Supremo Tribunal Federal não são revertidas em favor do réu e, por isso, seria razoável impor, desde logo, a pena a estes acusados.

Por outro lado, os fundamentos propriamente jurídicos expostos por estes julgadores não se sustentam. Por exemplo, entenderam que a presunção de inocência poderia ser invertida mesmo na pendência de recursos especial e extraordinário, eis que tais recursos não detêm efeito suspensivo e não permitem a análise de matéria fático-probatória. Além disso, argumentaram que o direito fundamental à presunção de inocência deveria ser reduzido para se tornar compatível com a efetividade do direito penal e a eficácia das decisões judiciais. Alguns afirmaram, ainda, a 
necessidade de contemplar a voz das ruas na interpretação constitucional mesmo que o tenham feito de forma tímida ${ }^{161}$.

Em contrapartida, os Ministros que rechaçaram a execução provisória da pena destacaram que, independentemente das normas infraconstitucionais a respeito dos efeitos recursais, é de hierarquia superior a previsão de que não há estabelecimento definitivo de culpa sem a constituição da coisa julgada material neste sentido. Isto é dizer que não é possível submeter um acusado a quaisquer medidas que se justifiquem pelo cometimento de um crime sem que haja sentença penal condenatória contra a qual não caiba ou não seja interposto recurso. Lembraram, também, que o Superior Tribunal de Justiça e o Supremo Tribunal Federal podem influir de forma expressiva nos casos concretos que chegam aos tribunais por meio de recurso especial e extraordinário. Apesar do efeito devolutivo destes recursos se deter à matéria de direito, estas instâncias especiais podem, ilustrativamente, decretar nulidades e devolver o processo ao Juízo de primeiro grau; alterar a pena imposta ao acusado e flexibilizar o tempo, o regime ou a espécie de sanção; bem como podem julgar atípica a conduta praticada pelo imputado e absolvê-lo da acusação. Além de outros fundamentos, assentaram não ser possível devolver a liberdade suprimida de um indivíduo por força de uma decisão modificada, o que fere de morte a reversibilidade que deve sustentar qualquer execução provisória de decisão judicial.

Apesar do atual entendimento - afirmado de forma tímida por uma maioria estreita -, é certo que o Supremo Tribunal Federal adota um posicionamento vacilante quanto à dimensão de tratamento do direito ao estado de inocência, tendo excepcionado a presunção de inocência de uma forma não prevista pela Constituição da República e não compatível com a

\footnotetext{
161 Como exemplo, transcreve-se trecho do voto do Ministro Luis Roberto Barroso no bojo das referidas ações declaratórias de constitucionalidade: "O STF é o intérprete final, mas não é o dono dela e nem tão pouco seu intérprete único. A definição do sentido e do alcance da Constituição cabe também à sociedade como um todo. Com as cautelas próprias, com os filtros adequados, não se deve ter a arrogância de se achar proprietário da Constituição.”
} 
ordem constitucional brasileira ao longo de 24 dos 31 anos de vigência da Lei Fundamental de 1988.

Ultrapassados tais exemplos, resta demonstrado que existe um "déficit cultural para a compreensão e concretização das normas que se extraem da "presunção de inocência"”. ${ }^{162}$ Tal deficiência pode até ser esperada pelo senso comum - usualmente apegado à repressão do outro. No entanto, não deve ser admitida quando oriunda de um órgão que, por essência, exerce a função de proteger a lei e, mais importante, tutelar direitos fundamentais - "que funcionam como "trunfos contra a maioria""163 - em uma dinâmica muitas vezes contra-majoritária a impedir a ditadura da multidão.

O estado crítico em que se encontra a efetivação da presunção de inocência motivou o enfoque ora deduzido neste trabalho. Também o fez a repetida ideia de que os meios de comunicação social contribuem para o lamentável cenário mencionado. Mais do que um argumento previsível, a contribuição do discurso midiático, embora não seja a única causa do desgaste da presunção de inocência, é, de fato, significativa para esta garantia restar prejudicada. Explica-se.

Conforme visto no capítulo anterior, os mecanismos de comunicação social apresentam a questão criminal por meio de uma realidade construída em que a validez da pena se revela uma obviedade. A mensagem transmitida pela criminologia midiática afirma que o poder punitivo nos salvaria dos maus elementos causadores de danos sociais. Por outro lado, a presunção de inocência, ao limitar a prática punitiva, atrapalharia a adequada resolução de conflitos da sociedade.

Outra seria a compreensão do estado de inocência não fosse o delito transmitido pelos instrumentos de comunicação social de forma

\footnotetext{
162 CASARA Rubens R R. Processo penal do espetáculo: e outros ensaios. $2^{\mathrm{a}}$ ed.. Florianópolis: Tirant lo Blanch, 2018. P. 63.

163 Ibid. P. 25.
} 
fundamentalmente descontextualizada e superficial. Ora, a presunção de inocência não surgiu do nada, mas a partir de experiências históricas que demonstraram a relevância de proteger o ser humano de qualquer violência - incluindo aquela perpetrada pelo ente público ou por outro similar. Analisar o fenômeno criminal por uma perspectiva profunda, passando pela vivência da humanidade, é fundamental para entender que não apenas os particulares são capazes de impor dor e sofrimento ao indivíduo, mas também os mecanismos do poder punitivo. Contudo, esta abordagem é ocultada pelos meios de comunicação social caracterizados, na esfera tradicional, pela des-historicidade e, no ambiente online, pelo fluxo descomedido de informação que prejudica a absorção de qualquer conteúdo.

A presunção de inocência não é apenas incompreendida em virtude do discurso midiático acerca da questão criminal, mas também rejeitada por força de suas palavras. Isto porque o medo ou a repulsa que a criminologia dos meios de comunicação social constrói em desfavor da figura do criminoso não se coaduna com a espera na aplicação da pena ou a necessidade de se demonstrar minuciosamente a existência do crime e a sua autoria. Na verdade, o constante apelo emotivo no trato do delito reclama um tratamento urgente e severo contra o imputado e, consequentemente, rechaça a cautela da presunção de inocência.

Além disso, a criminologia midiática logra romper a relação entre os criminalizados e os demais integrantes do sistema criminal e da sociedade, o que potencializa a adoção de medidas drásticas contra os imputados. O distanciamento que a mídia proporciona dentro da sociedade, mediante a dramatização do delito na televisão e o fechamento de conexões online, faz com que o campo social pouco se preocupe com deixar imaculados os direitos dos acusados - principalmente daqueles mais vulneráveis que se adequam ao estereótipo do criminoso. Nas palavras de Zaffaroni, os meios de comunicação social pensam que "as garantias penais são para nós, mas 
não para eles, pois eles não respeitam os direitos de ninguém. Eles - os estereotipados - não têm direitos, porque matam, não são pessoas, são diferentes." 164 Esta percepção do delinquente como um outro perigoso faz cair por terra o tratamento do imputado como sujeito de direitos - base de sustentação da presunção de inocência.

Tudo isto ocorre em uma dinâmica de grande influência do pensamento midiático sobre o sistema criminal. Afinal, o discurso repetido e uníssono da mídia tradicional sobre a questão criminal atinge um alcance incomparável com aquele das palavras da história ou da academia. Tal magnitude não deixa imune nem mesmo os operadores do sistema criminal, que são pressionados para corresponderem às expectativas da mídia. Não raras vezes, policiais, membros do Ministério Público e juízes permitem que seus atos sejam guiados da forma esperada pela opinião pública - ou publicada. Caso contrário, se preparam para receber ferozes críticas e associações com criminosos. Este influxo, no pensamento de Bordieu,

\begin{abstract}
pode ser muito bom, em certos casos, mas pode também pôr em perigo um estado, conquistado com dificuldade, de racionalidade coletiva; ou, mais precisamente, pôr em discussão aquisições certas e garantidas pela autonomia de um universo jurídico capaz de opor sua lógica própria às instituições do senso da justiça, do senso comum jurídico, frequentemente vítima das aparências ou das paixões. ${ }^{165}$

É justamente a concretude da presunção de inocência prevista em diplomas legais, constitucionais e internacionais que perde com o impacto da criminologia midiática sobre o sistema penal, responsável por consolidar um discurso punitivista junto ao campo social, segundo o qual a referida garantia é uma norma sem sentido voltada à proteção dos causadores de mal
\end{abstract} para a sociedade.

Em uma síntese do impacto do discurso midiático sobre a presunção inocência, são oportunos os dizeres de Nilo Batista, segundo o qual uma das consequências da lente ideológica que se interpõe entre o olhar da mídia e a vida

${ }^{164}$ ZAFFARONI, Eugenio Raul. A questão criminal. Rio de Janeiro: Revan, 2013. P. 203.

${ }^{165}$ BOURDIEU, Pierre. Sobre a televisão. Rio de Janeiro, Zahar, 1997. P. 81-82. 
reside no incômodo gerado pelos procedimentos legais que intervêm para a atestação judicial de que o delito efetivamente ocorreu e de que o infrator deve ser responsabilizado penalmente por seu cometimento. Tensões graves se instauram entre o delito-notícia, que reclama a imperativamente a pena-notícia, diante do devido processo legal (apresentado como um estorvo), da plenitude de defesa (o locus da malícia e da indiferença), da presunção de inocência (imaginese num flagrante gravado pela câmara!) e outras garantias do Estado democrático de direito, que só liberarão do verdugo quando o delito-processo alcançar o nível de delito-sentença (= pena-notícia). Muitas vezes essas tensões são resolvidas por alguns operadores - advogados, promotores ou juízes mais fracos e sensíveis às tentações da boa imagem - mediante flexibilização e cortes nas garantias que distanciam o delito-notícia da pena-notícia. ${ }^{166}$

${ }^{166}$ BATISTA, Nilo. Mídia e sistema penal no capitalismo tardio. Biblioteca on-line de ciências de comunicação, 2003. Disponível em: < http://www.bocc.ubi.pt/pag/batista-nilo-midia-sistemapenal.pdf >. Acesso em: 01/08/2019. P. 4. 


\section{TEMERIDADE DA RELAÇÃO CRIMINOLOGIA MIDIÁTICA - PRESUNÇÃO DE INOCÊNCIA}

No presente trabalho, foi vista a forma como o discurso pode influenciar a prática e a garantia jurídica. No capítulo um, restou estabelecido, por meio de uma análise histórica, que as teorias mais protetivas do indivíduo propiciaram práticas repressivas mais moderadas e melhor consolidaram garantias jurídicas - em oposição a pensamentos autoritários. No capítulo dois, já em uma abordagem mais específica, foi analisado como a palavra dos meios de comunicação social se alia a uma expressão opressiva, de modo a ser possível afirmar que a criminologia midiática consiste em um mecanismo que fortalece o exercício sancionatório do poder punitivo. No capítulo três, restou posto que a presunção de inocência, norma jurídica destinada a tutelar o indivíduo contra os arsenais da punição, se encontra ameaçada muito em razão do que os veículos de comunicação social reproduzem.

Agora, este estudo revela as razões pelas quais precisa ser evitada a relação descrita entre o discurso legitimante da prática punitiva propagado pela mídia e a efetivação da presunção de inocência. Em um primeiro momento, uma investigação de grandes massacres, traçada com base nas sempre precisas contribuições de Eugenio Raúl Zaffaroni, elucida a questão. Em um segundo momento, uma análise do conflito normativo entre a liberdade de expressão e a presunção de inocência o faz, a partir dos estudos de Robert Alexy e Ana Paula de Barcellos. O convite para pensar em alternativas que superem o cenário descrito é uma consequência natural.

\subsection{Uma análise por meio dos mortos}


Na obra A questão criminal, Zaffaroni propõe a verificação daquilo que é a única realidade da criminologia - ou, como é preferível pontuar, a verdade mais aproximada do fenômeno criminal -, qual seja, os mortos. A partir disso, o criminólogo assinala onde se encontraram cadáveres em grande número ao longo da história e quais as circunstâncias que o permearam. Excetuando as hipóteses de guerra, em que forças mais ou menos simétricas se enfrentaram, o professor aponta dezenas de massacres, definidos a partir do seguinte conceito criminológico:

Toda a prática de homicídio de um número considerável de pessoas por parte de agentes de um Estado ou de um grupo organizado com controle territorial, de forma direta ou com clara complacência destes, levada a cabo de forma conjunta ou continuada, fora das situações reais de guerra que importem forças mais ou menos simétricas. ${ }^{167}$

Seguem alguns destes episódios macabros apresentados por Zaffaroni $^{168}$.

O penalista lembra que o Império Romano provocou uma matança quando conquistou quase toda a Europa, bem como a Península Ibérica o fez quando subjugou e colonizou a América. O controle territorial policial europeu dizimou populações nativas de outros continentes também no período do neocolonialismo experimentado na África e nas ocupações anteriores do norte da África, Índia e Oceania. De acordo com seus dados,

Entre 1825 e 1830 os holandeses mataram cerca de 200.000 habitantes em Java, os portugueses uns 100.000 em Moçambique e os alemães 145.000 na África Oriental. A Argélia teve sua população reduzida em $15 \%$ entre 1830 e 1870 ; em toda a África francesa a população diminuiu um terço e a metade, no Congo belga em cerca de $50 \%$ (10.000.000), no Sudão inglês passou de nove para três milhões; algo análogo aconteceu na Oceania. A carestia cerealífera provocada pelo mercado livre, somado à seca, provocou mais de trinta milhões de mortes no Sudeste Asiático, na Índia e na África entre 1870 e 1890. Em 2 de outubro de 1904, o Império Alemão declarou que os hereros do África sul-ocidental deixavam de ser cidadãos alemães - o mesmo que foi feito, trinta anos depois, com os judeus e entre essa data e 1906 foram exterminados. ${ }^{169}$

$\mathrm{Na}$ América Latina, as mortes continuaram mesmo após a independência dos países colonizados em um fenômeno que Zaffaroni

\footnotetext{
${ }^{167}$ ZAFFARONI, Eugenio Raul. A questão criminal. Rio de Janeiro: Revan, 2013. P. 232.

168 Ibid. P. 226-238.

${ }^{169}$ Ibid. P. 236.
} 
denomina autocolonialismo. O apoio e a admiração que uma parte da população americana prestava aos invasores se transformou na aplicação de suas táticas contra os próprios compatriotas. Assim fizeram, por exemplo, na campanha ao deserto argentino, na contenção das mobilizações do Altiplano (Bolívia) contra a tentativa de reposição de lideranças indígenas, e em Canudos, no Nordeste do Brasil.

Mais tarde, por ocasião da Guerra Fria, repetiram esses esforços, valendo-se de uma importada doutrina da segurança nacional que passou a ser aplicada nas ditaduras militares espalhadas por toda a região. No Brasil, 434 mortos e desaparecidos foram confirmados pelo Estado no bojo da Comissão Nacional da Verdade, mas se estima que milhares de indígenas e camponeses também tenham sido vítimas de tais práticas. Isto fora os sobreviventes de tortura, exílio, prisão arbitrária e outras técnicas temerárias dos ditadores.

No século $\mathrm{XX}$, o criminólogo pontua que turcos massacraram armênios, nazistas aniquilaram judeus, ciganos, gays, dissidentes e doentes, bem como norte-americanos destruíram a população civil de Hiroshima e Nagasaki ${ }^{170}$. Ainda neste período, chama atenção a eliminação de 2.200 .000 de pessoas no Camboja sob o regime de Pol Pot, de 500.000 no Tibet pela ocupação chinesa e de 950.000 tutsis de Ruanda por hutus e aliados.

Apesar da inexatidão dos dados, Zaffaroni estima um cálculo de cem milhões de cadáveres, produzidos neste contexto de massacre no século passado. A partir de uma média entre as tabelas de Wayne Morrison e Rudolph J. Rummel, conclui que "mais de um em cada cinquenta habitantes do planeta foi morto pelos Estados no decorrer do século passado, sem contar os mortos em guerras." ${ }^{171}$ Trata-se de um numerário alarmante.

\footnotetext{
170 Tais episódios se amoldam ao conceito de massacre, eis que, mesmo contemporâneos a guerras, não envolveram forças armadas mais ou menos simétricas. Além disso, não vitimaram combatentes, vencidos ou prisioneiros de guerra. Nas palavras do autor: "Numerosos massacres pretenderam se confundir com guerras. [...] Se bem às vezes há massacres coetâneos, decididos e executados aproveitando a guerra, nada têm a ver com ela mesma." Cf. Ibid. P. 235.

${ }^{171}$ Ibid. P. 227-228.
} 
A par destes e de outros homicídios em massa, o criminólogo pretende responder as seguintes perguntas sobre os mortos: o que? como? onde? quando? com o que? por quê? quem $?^{172}$

A mais preciosa conclusão a que chega Zaffaroni é que o poder punitivo é o meio através do qual se executam massacres. Ele lembra que cada um destes eventos contou com o controle de territórios, o aniquilamento de rebeldes, a eliminação de indesejáveis, o castigo dos renitentes e a imposição de trabalho forçado. Todas estas atividades mesmo que perpetradas por militares, organizações políticas uniformizadas ou bandos - são próprias da função policial.

Por outro lado, ressalta que não foi qualquer exercício do poder punitivo que resultou em matanças ao longo da história, mas sim aquele descontrolado e mobilizado por um Estado ou um grupo hegemônico que pretendeu acumular poder irrestritamente. Para tanto, estes entes poderosos comumente apontaram todo o problema social existente como consequência da atuação de determinado bode expiatório. Dito de outra forma, eles projetaram certos grupos humanos historicamente desajustados como causadores de toda a emergência e o pânico que se encontravam no campo social, de modo a demandar sua eliminação como forma de pacificação da sociedade. Foi o que se verificou no linchamento de judeus por poloneses e lituanos, no assassinato de hutus por tutsis, na eliminação de comunistas pela ditadura brasileira, etc.

A ideia de que determinada categoria humana seria responsável por todo o mal da sociedade é extremamente irracional e, em geral, calcada em preconceito. Contudo, é bem aceita pelo senso comum por ser confortável saber que todo o mal-estar da existência tem uma origem única que, por conseguinte, pode ser facilmente destruída.

O alarde produzido junto à opinião pública contra a classe inimiga é tamanho que torna irrestrito o âmbito de exercício do poder punitivo 
destinado a eliminá-la. E esse é justamente o intuito principal do grupo político que põe em prática o massacre: criar espaço para um poder concentrado e hierarquizado se desenvolver sem limites e da forma que bem quer. No mais, a emergência social invocada se revela apenas como pretexto para a expansão dos domínios de tal ente. Tal constatação resta nítida quando se percebe que nenhum problema da sociedade jamais foi resolvido com o agigantamento irrestrito do poder punitivo. A saber,

Satã está um pouco cabisbaixo, com seu tridente sem ponta e sua cauda quebrada; o alcoolismo continua fazendo estragos; as drogas se expandem cada dia mais; a sífilis foi resolvida com penicilina; a tuberculose com a estreptomicina; os hereges fizeram suas igrejas nacionais; a degeneração da espécie e o perigo das raças inferiores passaram a ser uma grande mentira; as bruxas continuaram cozinhando seus cozidos esquisitos e no máximo criaram algum problema bromatológico. ${ }^{173}$

Para o êxito desta política que não apresenta qualquer apreço à vida, é imprescindível que as cúpulas do poder público estejam acompanhadas por uma indiferença do espaço político internacional e por um discurso de neutralização do outro, dentre os quais se destaca a teorização do nazista Carl Schmitt. É de bom tom ressalvar que o êxito do massacre não significa dizer que ele provoque um resultado satisfatório para qualquer envolvido. $\mathrm{Na}$ verdade, nem mesmo as categorias que mobilizam tal estratégia de concentração de domínios foram agraciadas com a sua aplicação, sendo fato que

o Império Otomano se dissolveu e a Turquia até hoje não conseguiu entrar na União Europeia; a Alemanha nazista acabou no desastre que todos conhecemos; o regime de Pol Pot foi derrubado e o Camboja ficou sem profissionais nem serviços. ${ }^{174}$

Em suma, pode-se afirmar, partindo de Zaffaroni, que um número considerável de assassinatos foi produzido historicamente mediante grupos no poder que decidiram montar um Estado policial a fim eliminar as limitações de seu poder e aniquilar uma massa humana que rotula e substancializa como inimiga. Isso não seria possível sem o aval da opinião

\footnotetext{
173 Ibid. P. 32.

${ }^{174}$ Ibid. P. 240.
} 
pública, a indiferença do campo internacional e o impulsionamento promovido pelos discursos teóricos funcionais a esta prática.

Tais mortes - ressalte-se, de verdade significativamente aproximada - revelam o perigo mais significativo a existir na vida em sociedade. Este risco está presente no mecanismo punitivo estatal que atentou contra a população que estava destinado a proteger por não raras vezes. A violência de Estado é a pior agressão que pode existir, não apenas pelo seu alto índice de letalidade, mas também por mobilizar a força sob um pressuposto singular de legitimidade. A disposição monopolista dos meios legítimos de violência sempre dificulta - para dizer o mínimo - o questionamento da coerção abusiva do poder punitivo, bem como a resistência válida de qualquer oponente seu.

Cumpre salientar que a matança produzida pelo instrumento penal não se trata de uma hipótese remota, mas sempre presente em potencial na prática de punir. Isto porque o uso constante da força na resolução de determinados conflitos proporciona uma concentração formidável de poder que, sem a imposição de restrições, se expande indefinidamente ao argumento de precisar abater o inimigo ou colonizar o inferior. $\mathrm{Na}$ experiência histórica, desde os séculos XI e XIII até o presente, o confisco da vítima propôs soluções verticais para os conflitos da sociedade, o que teve como caminho repetido a hierarquização interna e a expansão de hegemonia para outros territórios. Sempre se verificou a tendência de as agências executivas do poder de punir se descontrolarem sob o pretexto de combater inimigos causadores de emergências para a humanidade, sem que, de fato, eliminassem a crise social.

Importante ressaltar, também, que a brutalidade do sistema punitivo não se encontra distante no tempo e no espaço geográfico. Isto porque verdadeiros massacres a conta-gotas ${ }^{175}$ estão em curso no Brasil, podendo ser encontrados principalmente nas execuções extrajudiciais cometidas por

${ }^{175}$ Ibid. P. 271. 
policiais dentro e fora de serviço. No país, o número de mortes provocadas em intervenções policiais é um destaque mundial, mesmo em período de aparente estabilidade democrática. Um estudo de Luís Felipe Zilli aponta que

em 2016, enquanto o Brasil apresentou uma taxa de aproximadamente duas mortes decorrentes de intervenções policiais para cada grupo de $100 \mathrm{mil}$ habitantes, na África do Sul essa taxa foi de pouco mais de uma morte; no México, não chegou a 0,3 ; mesmo nos Estados Unidos, país com aproximadamente 900 mil agentes policiais em atividade (no Brasil são pouco mais de 500 mil), este indicador chegou a 0,13 morte para cada grupo de $100 \mathrm{mil}$ habitantes. ${ }^{176}$

Embora as estatísticas criminais sempre englobem problemas de precariedade em sua produção, é preciso considerar os números apresentados pelo Fórum Nacional de Segurança Pública ${ }^{177}$. De acordo com dados desta organização, as mortes decorrentes de intervenções policiais em serviço e fora de serviço cresce anualmente desde 2013. Só em 2018 foram 6.220 vítimas da dinâmica policial - em uma proporção de um policial morto para cada 18 mortes cometidas pela polícia - o que totaliza $11,45 \%$ do total das mortes violentas intencionais no Brasil neste ano. Importante frisar que a quantidade de agentes assassinados é composta majoritariamente por episódios ocorridos fora de serviço.

Como se pode supor a partir destes números elevados, as mortes perpetradas pelo Estado não são ocasionadas por uma conduta equivocada ou desviada do agente de polícia. Na verdade, correspondem a uma verdadeira política de extermínio de parte da população brasileira.

Isto ficou nítido com as pesquisas de Orlando Zaccone. Na obra Indignos de vida: a forma jurídica da política de extermínio de inimigos na cidade do Rio de Janeiro, o eminente Delegado de Polícia levantou 314

\footnotetext{
176 ZILLI, Luís Felipe. Letalidade e Vitimização Policial: características gerais do fenômeno em três estados brasileiros. Boletim de análise política institucional, n. 17, dez. 2018. Disponível em: $<$ http://repositorio.ipea.gov.br/bitstream/11058/8873/1/bapi_17_cap_10.pdf $>$. Acesso em 24/10/19. P. 72.

177 BUENO, Samira; LIMA, Renato Sérgio de. Anuário brasileiro de segurança pública 2019. Fórum Brasileiro de Segurança Pública, a. 13, 2019. Disponível em: < http://www.forumseguranca.org.br/wp-content/uploads/2019/09/Anuario-2019-FINAL-v3.pdf > Acesso em 20/11/19.
} 
promoções de arquivamento do Ministério Público do Rio de Janeiro, proferidas entre os anos de 2003 e 2009, no bojo dos chamados autos de resistência.

Nestes pronunciamentos, verificou como que sujeitos negros, jovens e periféricos tiveram suas vidas ceifadas em atuações policiais reiteradamente legitimadas pelo órgão ministerial. Ressaltou que não foram realizadas investigações substanciais dos homicídios ocorridos em intervenções da Polícia, sendo certo que pouco se ocuparam das circunstâncias da morte e muito se voltaram à vida dos ofendidos em territórios pobres. Por isso era comum que a folha de antecedentes criminais do morto fosse juntada aos autos e seus familiares e conhecidos ouvidos em sede policial, em uma dinâmica peculiar aos demais inquéritos de homicídios. A condição de vida da vítima foi sistematicamente considerada pelo Ministério Público como justificativa para a sua morte, sendo comum o arquivamento do inquérito sobre o homicídio a partir da união dos mais frágeis indícios a apontar um passado supostamente criminoso do morto, mesmo que contrários aos depoimentos colhidos sobre a dinâmica dos fatos e ao local do ferimento causado pelo projétil de arma de fogo. Por conseguinte, a legítima defesa do agente policial foi presumida indistintamente, de modo a dar respaldo legal à prática de derramamento de sangue de determinados setores da capital fluminense.

Depois, a política de extermínio em curso pelo poder punitivo estatal ficou escancarada com as atuações de determinados representantes do Poder Executivo do país. As palavras e a política do atual governador do Estado do Rio de Janeiro se destacam, notadamente pela defesa espetaculosa do abate de supostos delinquentes. Desde a concessão de entrevistas em que afirma ser necessário que o Estado atire na cabeça de indivíduos até a edição de decreto em que retira o bônus até então conferido à Polícia pela 
redução de mortes em confronto ${ }^{178}$, o antigo magistrado não esconde seu desapego à vida, que já se reflete na elevação dos números de assassinatos por intervenção no Estado do Rio de Janeiro ${ }^{179}$.

É justamente esta potencialidade próxima e recorrente do poder punitivo causar numerosas mortes que deve saltar aos nossos olhos e impulsionar nossa ação no sentido de evitá-la.

Uma das melhores formas de se obstar massacres se encontra na contenção do instrumento punitivo através do direito penal latu sensu, regulado pelo Poder Legislativo e aplicado pelo Judiciário. Isto porque as normas jurídicas têm o condão de limitar o poder penal absoluto por dizerem quando e como punir, quando e como proibir, bem como quando e como julgar ${ }^{180}$. Dito de outra forma, as garantias penais e processuais penais condicionam ou vinculam o exercício da potestade punitiva por afirmarem quando e como da intervenção penal ${ }^{181}$.

Foi preciso passar pelos desastres do absolutismo do antigo regime e do totalitarismo dos governos nazifascistas para que garantias individuais contra o poderoso mecanismo punitivo fossem consolidadas como direitos naturais ou direitos humanos. Particularmente, a presunção de inocência, como garantia fundamental que impõe uma máxima prudência à prática penal, se desenvolveu durante os períodos históricos caracterizados por maior igualdade e liberdade à pessoa. ${ }^{182}$

Na contramão desta conquista civilizatória, a criminologia midiática caminha para a aceleração do massacre na medida em que desacredita as garantias jurídicas, notadamente a presunção de inocência. Dito por outras

\footnotetext{
${ }^{178}$ Cf. Decreto 46.775/2019, publicado na edição de 24/09/19 do Diário Oficial do Estado do Rio de Janeiro.

179 ALBUQUERQUE, Ana Luiza. Morte por intervenção do Estado atinge maior patamar em 20 anos no Rio. Folha de S. Paulo, 21 ago. 2019. Disponível em: < https://www1.folha.uol.com.br/cotidiano/2019/08/morte-por-intervencao-do-estado-atinge-maiorpatamar-em-20-anos-no-rio.shtml >. Acesso em 28/10/19.

180 FERRAJOLI, Luigi. Direito e razão: teoria do garantismo penal. $3^{\mathrm{a}}$ ed.. rev. São Paulo: Editora Revista dos Tribunais, 2002. P. 74-75.

181 Ibid. P. 74-75.

${ }^{182} \mathrm{Cf}$. descrito no capítulo um deste trabalho.
} 
palavras, a mídia assume o lugar de propagação de uma violência que desemboca em sofrimentos e mortes reais ao renegar o direito e estimular o agigantamento do punitivismo mediante o poder de punir.

Destaque-se que o apelo emotivo propagado pelos mecanismos de comunicação social no trato do delito ajuda a construir o cenário irracional de paranoia coletiva contra determinado grupo humano eleito como inimigo. Trata-se de terreno fértil para a perseguição de bodes expiatórios que caracteriza a dinâmica de um massacre. Além disso, a desinformação que é típica do discurso criminológico dos meios comunicacionais administra o medo no campo social de forma temerária: o crime do particular concentra todo o mal do mundo e o desvio institucional do poder de punir sequer recebe importância. Não há receio, sobretudo, do Estado repressivo. Nesse jogo cúmplice de luz e de escuridão propagado pela mídia, é certo que "por temor ao roubo peço mais vigilância ao Estado e quando dou por mim aqueles que me vigiam me sequestram." 183

Diante do exposto, depreende-se que a palavra da criminologia midiática não merece prosperar por desvencilhar o poder punitivo de suas amarras de contenção e, consequentemente, estimular a hipertrofia de uma prática que pode se desenvolver de forma fundamentalmente destrutiva.

Um passo para a modificação deste cenário pode ser estimular o aprendizado sobre o sistema criminal, principalmente de uma perspectiva criminológica, ainda que o discurso retratado decorra mais da influência de poderosos enviesados do que da atuação de uma massa de jornalistas e internautas desavisados. ${ }^{184}$ Outro passo neste sentido reside na ocupação dos espaços de comunicação de massa por criminólogos. Considerando que vivemos em pleno período de revolução tecnológica-comunicacional, é importante que saberes como o estampado neste tópico ultrapassem a

${ }^{183}$ ZAFFARONI, Eugenio Raul. A questão criminal. Rio de Janeiro: Revan, 2013. P. 208.

${ }^{184}$ A especialização de profissionais da mídia no sistema de justiça penal é também apontada na já mencionada obra jornalística de Silvia Ramos e Anabela Paiva. Vide RAMOS, Silvia; PAIVA, Anabela. Mídia e violência: tendências na cobertura de criminalidade e segurança no Brasil. Rio de Janeiro: IUPERJ, 2007. P. 26. 
solidão da academia e contestem em alto e bom som a publicidade do poder

punitivo que hoje é hegemônica na mídia. ${ }^{185}$

\subsection{Um exame por meio do direito}

É certo que os discursos, mesmo que críticos, minoritários ou extremistas, estão abarcados pela liberdade de expressão, qual seja, um direito fundamental garantido em normas jurídicas de âmbito constitucional $^{186}$ e internacional ${ }^{187}$. Na percepção de Jónatas Machado, o

\footnotetext{
${ }^{185}$ ZAFFARONI, Eugenio Raúl. Op. cit. P. 7-10.

${ }^{186}$ Cita-se alguns dos dispositivos da Constituição da República Federativa do Brasil que dispõem sobre a matéria: "Art. 220. A manifestação do pensamento, a criação, a expressão e a informação, sob qualquer forma, processo ou veículo não sofrerão qualquer restrição, observado o disposto nesta Constituição. $\S 1^{\circ}$ Nenhuma lei conterá dispositivo que possa constituir embaraço à plena liberdade de informação jornalística em qualquer veículo de comunicação social, observado o disposto no art. $5^{\circ}$, IV, V, X, XIII e XIV. § $2^{\circ}$ É vedada toda e qualquer censura de natureza política, ideológica e artística."
}

"Art. 5". IV - é livre a manifestação do pensamento, sendo vedado o anonimato; V - é assegurado o direito de resposta, proporcional ao agravo, além da indenização por dano material, moral ou à imagem; IX - é livre a expressão da atividade intelectual, artística, científica e de comunicação, independentemente de censura ou licença; X - são invioláveis a intimidade, a vida privada, a honra e a imagem das pessoas, assegurado o direito a indenização pelo dano material ou moral decorrente de sua violação; XIV - é assegurado a todos o acesso à informação e resguardado o sigilo da fonte, quando necessário ao exercício profissional;"

187 A Convenção Americana de Direitos Humanos estabelece o seguinte sobre liberdade de expressão: "Artigo 13. Liberdade de pensamento e de expressão 1. Toda pessoa tem direito à liberdade de pensamento e de expressão. Esse direito compreende a liberdade de buscar, receber e difundir informações e idéias de toda natureza, sem consideração de fronteiras, verbalmente ou por escrito, ou em forma impressa ou artística, ou por qualquer outro processo de sua escolha. 2. O exercício do direito previsto no inciso precedente não pode estar sujeito a censura prévia, mas a responsabilidades ulteriores, que devem ser expressamente fixadas pela lei e ser necessárias para assegurar: a. o respeito aos direitos ou à reputação das demais pessoas; ou b. a proteção da segurança nacional, da ordem pública, ou da saúde ou da moral públicas. 3. Não se pode restringir o direito de expressão por vias ou meios indiretos, tais como o abuso de controles oficiais ou particulares de papel de imprensa, de frequiências radioelétricas ou de equipamentos e aparelhos usados na difusão de informação, nem por quaisquer outros meios destinados a obstar a comunicação e a circulação de idéias e opiniões. 4. A lei pode submeter os espetáculos públicos a censura prévia, com o objetivo exclusivo de regular o acesso a eles, para proteção moral da infância e da adolescência, sem prejuízo do disposto no inciso 2. 5. A lei deve proibir toda propaganda a favor da guerra, bem como toda apologia ao ódio nacional, racial ou religioso que constitua incitação à discriminação, à hostilidade, ao crime ou à violência."

O Pacto Internacional de Direitos Civis e Políticos também assegura a liberdade de expressão nos seguintes termos: "ARTIGO 19. 1. ninguém poderá ser molestado por suas opiniões. 2. Toda pessoa terá direito à liberdade de expressão; esse direito incluirá a liberdade de procurar, receber e difundir informações e idéias de qualquer natureza, independentemente de considerações de fronteiras, verbalmente ou por escrito, em forma impressa ou artística, ou por qualquer outro meio de sua escolha. 3. O exercício do direito previsto no parágrafo 2 do presente artigo implicará deveres e responsabilidades especiais. Conseqüentemente, poderá estar sujeito a certas restrições, que devem, entretanto, ser expressamente previstas em lei e que se façam necessárias para: a) 
motivo desta proteção se assenta em um equilíbrio entre razões de cunho social e individual. De forma sucinta, pode-se dizer que este professor interpreta o direito à liberdade de expressão de forma aberta e multifuncional. Por um lado, sustenta que a finalidade deste direito consiste em proporcionar um livre embate de ideias e circulação de informações, o que traz efeitos positivos para a coletividade. A livre expressão potencializa a formação de um melhor juízo e a fiscalização das autoridades que, por sua vez, favorecem a autodeterminação democrática. Por outro lado, aduz que o objetivo da liberdade de expressão também se encontra em propiciar autonomia e autorrealização individual ao reconhecer a prerrogativa de cada pessoa se expressar da forma que desejar. ${ }^{188}$

Embora adote uma visão protetiva da liberdade de expressão, Machado admite que o referido direito pode ser objeto de restrição, por meio de ponderação, na hipótese de colidir com outros interesses de importância equivalente ${ }^{189}$. O Supremo Tribunal Federal adota posição similar ao prestigiar a livre expressão, embora não a reconheça como direito absoluto - ou o faça com qualquer outra garantia. ${ }^{190}$

Dito isto, é importante verificar se o discurso dos meios de comunicação social sobre a questão criminal consiste em uma forma legítima ou abusiva de exercício do direito à liberdade de expressão. Para

assegurar o respeito dos direitos e da reputação das demais pessoas; b) proteger a segurança nacional, a ordem, a saúde ou a moral públicas. ARTIGO 20 1. Será proibida por lei qualquer propaganda em favor da guerra. 2. Será proibida por lei qualquer apologia do ódio nacional, racial ou religioso que constitua incitamento à discriminação, à hostilidade ou a violência."

188 Para mais informações vide MACHADO, Jónatas E. M. Liberdade de expressão - Dimensões Constitucionais da esfera pública no sistema social. Coimbra: Coimbra editora. 2002. 1196 p.

${ }^{189}$ Ibid. P. 418.

190 Neste sentido, cita-se dois julgados. No bojo da Ação de Descumprimento de Preceito Fundamental $n^{\circ} 130 /$ DF, em que este Tribunal declarou a Lei de Imprensa do período ditatorial como não recepcionada pela Constituição Federal de 1988, restou consolidada a precedência da liberdade de expressão, notadamente da liberdade de imprensa, em face dos direitos à imagem, honra, intimidade e vida privada. No caso de conflito entre estes blocos de direitos, o primeiro se antecede no tempo e o segundo é resguardado a posteriori pelo direito de resposta e pelo regime de responsabilização civil, administrativa e penal. Por outro lado, no julgamento do Habeas Corpus 82424 / RS, em que discutiu a conduta de escrever e publicar livros com ideias antissemitas, esta Corte destacou que a garantia constitucional da liberdade de expressão não é incondicionada. $\mathrm{Na}$ verdade, ela deve ser exercida de forma harmônica com os limites impostos pela própria Lei Fundamental do Brasil, especialmente a dignidade da pessoa humana e a igualdade jurídica que, junto aos direitos humanos, prevalecem sob a ordem do Estado Democrático de Direito. 
tanto, é preciso recordar os fatos relevantes que dizem respeito a esta palavra e repisar que o discurso criminológico dos meios comunicacionais prejudica a efetivação de garantias fundamentais.

A criminologia midiática é caracterizada por homogeneamente abordar o delito de uma perspectiva superficial, descontextualizada, acrítica e apelativa. Além disso, os meios de comunicação social, conduzidos pelo poder político e econômico ou no interesse desta categoria, constroem uma realidade favorável à exclusão de certos grupos humanos tidos como causadores do caos social. ${ }^{191}$ Por estes e outros fatores, a mídia corresponde a um mecanismo "incondicionalmente legitimante" 192 ou um "aparato de publicidade" 193 do sistema penal.

Por outro lado, a presunção de inocência, particularmente, perde observância como instituição jurídica, na medida em que é tratada pela mídia como impasse ao funcionamento da prática punitiva, que supostamente salvaria a boa sociedade dos maus elementos. ${ }^{194}$ A perda de concretude deste direito significa o desprestígio de uma norma que protege o indivíduo contra os sempre perigosos instrumentos de violência do Estado. Na prática, o esvaziamento do estado de inocência implica, sobretudo, na inocuidade de um mecanismo relevante de tutela da categoria mais vulnerável do campo social, tendo em vista a seletividade estrutural do poder punitivo que a persegue ${ }^{195}$.

Ora, a referida tensão que existe entre a liberdade de expressão e a presunção de inocência configura uma colisão de direitos fundamentais em sentido estrito que clama por alguma forma de superação. Dentre os diversos autores que se debruçam sobre o tema, dois expoentes são destacados no presente trabalho para, inicialmente, explicar a colisão de

\footnotetext{
${ }^{191}$ Cf. aduzido no capítulo dois.

${ }^{192}$ BATISTA, Nilo. Mídia e sistema penal no capitalismo tardio. Biblioteca on-line de ciências de comunicação, 2003. Disponível em: < http://www.bocc.ubi.pt/pag/batista-nilo-midia-sistemapenal.pdf >. Acesso em: 01/08/2019. P. 3.

${ }^{193}$ ZAFFARONI, Eugenio Raul. A questão criminal. Rio de Janeiro: Revan, 2013. P. 266.

${ }^{194}$ Cf. exposto no capitulo três.

${ }^{195}$ ZAFFARONI, Eugenio Raúl. Op. cit. P. 259.
} 
direitos fundamentais e a sua forma de resolução e, depois, voltar à análise do conflito em comento.

Nas palavras de Robert Alexy,

colisões de direitos fundamentais em sentido estrito nascem [...] quando o exercício ou a realização do direito fundamental de um titular de direitos fundamentais tem consequências negativas sobre direitos fundamentais de outros titulares de direitos fundamentais. ${ }^{196}$

Neste cenário, o renomado professor prestigia a ponderação como meio por excelência de solução das referidas colisões, adotando a teoria dos princípios a fim de garantir maior efetividade a todo catálogo de direitos fundamentais. ${ }^{197}$ De forma sucinta, o referido método pode ser enunciado por meio da seguinte "lei de ponderação": "Quanto mais intensa é uma intervenção em um direito fundamental tanto mais graves devem ser as razões que a justificam." 198 Alexy prega, ainda, que, na primeira fase da ponderação, se analise a intensidade da intervenção no direito sacrificado; na segunda, se avalie a importância das razões que justificam o sacrifício; e, por fim, na terceira fase, se faça a ponderação no sentido estrito e próprio. ${ }^{199}$

Ana Paula de Barcellos reforça o sopesamento, definindo-o como "técnica de decisão jurídica empregada para solucionar conflitos normativos que envolvam valores ou opções políticas em tensão, insuperáveis pelas formas hermenêuticas tradicionais"200. No mais, a constitucionalista pretende conferir-lhe maior juridicidade e racionalidade, o que faz por meio de uma proposta de ordenação metodológica para a

\footnotetext{
${ }^{196}$ ALEXY, Robert. Colisão de Direitos Fundamentais e Realização de Direitos Fundamentais no Estado de Direito Democrático. Revista da Faculdade de Direito da Universidade Federal do Rio Grande do Sul, v. 17, 1999. P. 269.

${ }^{197}$ A teoria dos princípios reconhece que os direitos fundamentais são compostos por regras e também por princípios, atrás e ao lado das regras. Diferentemente, a teoria das regras é tida por Alexy como aquela que afirma que catálogos de direitos fundamentais são compostos apenas por regras. Esta última teoria incorreria no esvaziamento dos direitos fundamentais, uma vez que a colisão entre eles teria de ser resolvida com intervenções drásticas pelas regras a serem aplicadas na forma do "tudo ou nada", motivo pela qual é rejeitada pelo professor. Cf. Ibid. P. 267-279.

198 Ibid. P. 278.

${ }^{199}$ Ibid. P. 277-279.

200 BARCELLOS, Ana Paula de. Ponderação, racionalidade e atividade jurisdicional. Rio de Janeiro: Renovar, 2005. P. 18.
} 
técnica, bem como de uma sugestão de parâmetros gerais e específicos capazes de nortear uma decisão legítima e previsível. ${ }^{201}$

De acordo com a teoria de Barcellos, a ordenação metodológica da ponderação se divide em três etapas. Na primeira delas, todos os enunciados normativos aparentemente em conflito na hipótese são identificados e agrupados em função das soluções que indiquem para o caso. Na segunda, as circunstâncias concretas do caso e suas repercussões sobre os enunciados são examinados. Na terceira etapa do processo ponderativo, uma decisão é tomada, com a advertência - que ora se destaca - de que não se deve restringir demais nenhum dos elementos em questão. Para servir de norte ao intérprete, são propostos, ainda, os seguintes parâmetros gerais:

(i) os enunciados com estrutura de regra (dentre os quais os núcleos dos princípios que possam ser descritos dessa forma) têm preferência sobre aqueles com estrutura de princípios; e (ii) as normas que promovem diretamente os direitos fundamentais dos indivíduos e a dignidade humana têm preferência sobre aqueles que apenas indiretamente contribuem para esse resultado. ${ }^{202}$

No caso de conflito entre enunciados específicos, é sugerida a construção de parâmetros particulares que pode ser feita por meio dos seguintes elementos: (i) as características próprias da estrutura de cada enunciado; (ii) o conteúdo de cada enunciado; e (iii) as circunstâncias que interferem com sua aplicação, inclusive situações de conflito com outros enunciados.

Retomando o conflito sob análise, é mister perceber que a liberdade de expressão, exercida pelos meios de comunicação social hegemônicos, nos moldes descritos ao longo do presente estudo, tem consequências negativas sobre a presunção de inocência, usufruída pelos demandados criminalmente. Portanto, se está diante de uma colisão de direitos fundamentais na forma definida por Alexy.

201 Ibid. P. 20.

202 Ibid. P. 303. 
Ambos os direitos mencionados tratam-se de normas-princípios ${ }^{203}$, alçados à mesma hierarquia de direitos fundamentais por decorrência de escolhas juspolíticas neste sentido. Particularmente, a mídia tem usado o manto da liberdade de expressão, em tese voltado ao aprimoramento do autogoverno e à autorrealização pessoal, para expor certos indivíduos ao ponto de esvaziar a caríssima presunção de inocência que serve como garantia da liberdade de ir, vir e permanecer, bem como da capacidade de se autodeterminar. Nas palavras de Carnelutti, o abuso da liberdade de imprensa transforma o indivíduo em pedaços. "E o indivíduo, recordemonos, é o único valor que deveria ser salvo pela civilidade."204 Assim, observada a presença das condições descritas ao longo do trabalho, a presunção de inocência deveria se sobrepor à liberdade de expressão por realizar mais diretamente a dignidade humana, de acordo com os parâmetros de Barcellos.

Impende ressalvar que não se quer aqui inverter totalmente a balança e vilipendiar a liberdade de expressão. Na verdade, a intenção é de advogar pura e simplesmente pela busca da harmonia entre a liberdade de expressão dos discursos criminológicos e a presunção de inocência por meio da ponderação, de forma que o segundo direito mencionado seja assegurado sem que o primeiro seja exposto a formas muito intensas de intervenção.

Seja como for, o mais importante é notar que o vínculo manifestado ao longo do presente trabalho entre discurso (unido à prática punitiva) e garantia da presunção de inocência é composto pelo exercício ilimitado da

\footnotetext{
${ }^{203}$ Partindo da contribuição de Alexy e Dworkin, Humberto Ávila busca aperfeiçoar os critérios para definir e distinguir regras e princípios. Destaca-se a seguinte forma de diferenciação: "As regras são normas imediatamente descritivas, na medida em que estabelecem obrigações, permissões e proibições mediante a descrição da conduta a ser cumprida. Os princípios são normas imediatamente finalísticas, já que estabelecem um estado de coisas cuja promoção gradual depende dos efeitos decorrentes da adoção de comportamentos a ela necessários. Os princípios são normas cuja qualidade frontal é, justamente, a determinação da realização de um fim juridicamente relevante, ao passo que característica dianteira das regras é a previsão do comportamento." ÁVILA, Humberto. Teoria dos princípios - da definição à aplicação dos princípios jurídicos. $4^{\mathrm{a}}$ ed.. São Paulo: Malheiros Editores, 2005. A partir disso, é possível afirmar que tanto a liberdade de expressão quanto a presunção de inocência melhor se adequam à categoria de princípios, embora o direito que expressam também se manifeste em normas com natureza de regras.

${ }^{204}$ CARNELUTTI, Francesco. As misérias do processo penal. São Paulo: Editora Pilares, 2009. P. 66-67.
} 
liberdade de expressão que prejudica demasiadamente o direito ao estado de inocência como bem de todos. Na ausência de um sopesamento que considere os valores em jogo, é certo que a palavra da criminologia midiática não está juridicamente resguardada e, por mais este motivo, merece a rejeição.

Algumas sugestões de como efetivamente superar essa colisão de direitos fundamentais, à luz do ordenamento jurídico brasileiro, podem ser encontradas na doutrina, na jurisprudência e no direito comparado, o que ora se passa a comentar.

$\mathrm{Na}$ doutrina, a professora Simone Schreiber estudou como a cobertura midiática sobre os delitos, notadamente a que se concretize como militância no "combate ao crime" ou campanha pela condenação do imputado $^{205}$, pode comprometer o direito ao julgamento justo, entendido como aquele regido pelas garantias do devido processo legal, incluindo a presunção de inocência. Nessa situação de conflito da liberdade de expressão e de informação versus o direito a um julgamento criminal justo, a penalista fixa standards que podem nortear a sua ponderação em casos concretos e individualmente considerados, a partir das referidas lições de Ana Paula de Barcellos.

Aplicando os parâmetros gerais propostos por Barcellos, Simone conclui que, em primeiro lugar, "se alguma regra relacionada com os princípios da liberdade de expressão ou do julgamento justo estiver envolvida na colisão, a balança penderá a favor do princípio amparado pela

\footnotetext{
${ }^{205}$ Schreiber identifica as possíveis situações de cobertura ilícita de um julgamento criminal pela mídia por meio dos seguintes elementos: 1. Manifestações expressivas sucessivas prejudiciais ao réu, como sustentando a culpa e sua rápida condenação, veiculando provas obtidas por meios ilícitos e inserção significativa sobre o tema; 2. A potencialidade de que tais manifestações interfiram na imparcialidade dos julgadores e no resultado do processo, não se exigindo a demonstração da influência; e 3. A contemporaneidade da publicidade com a investigação e o julgamento. SCHREIBER, Simone. A publicidade opressiva de julgamentos criminais - Uma investigação sobre as consequências e formas de superação da colisão entre a liberdade de expressão e informação e o direito ao julgamento criminal justo, sob a perspectiva da Constituição brasileira de 1988. Rio de Janeiro: Renovar, 2008. P. 373-380.
} 
regra."206207 Na hipótese concreta, não havendo regra específica relacionada aos direitos em conflito, Schreiber depreende que, em segundo lugar, a "preferência prima facie recaia sobre o direito do acusado ao julgamento criminal justo". Isto por entender que

a garantia de ser julgado sob o devido processo legal realiza mais diretamente a dignidade da pessoa humana do que a liberdade de expressão. Ou, dito de outra forma, não restringir a campanha de mídia contra o réu reduzindo suas chances de ter um julgamento justo viola mais o princípio da dignidade da pessoa humana do que restringir tópica e fundamentadamente a manifestação expressiva potencialmente prejudicial. ${ }^{208}$

Para consolidar esta tese, a criminalista não menosprezou a relevância da liberdade de expressão, compartilhando, inclusive, da protetiva doutrina de Jónatas Machado sobre o referido direito. Ressalte-se que Simone Schreiber identifica a ocorrência de um crime como acontecimento público e, consequentemente, entende o interesse da coletividade em sua apuração e punição como legítimo ${ }^{209}$. Ademais, aponta que o Poder Judiciário exerce parcela do poder estatal e, por isso, deve ser transparente, bem como estar sujeito ao escrutínio público. ${ }^{210}$ Por outro lado, preconiza que o papel que a imprensa se atribui seja desmistificado com o fito de proporcionar uma ponderação adequada entre os direitos fundamentais em atrito. Em suas palavras,

O que se está defendendo é a compreensão das manifestações midiáticas como expressões que decorrem de decisões políticas (e não técnicas), sujeitas às leis de mercado, refletindo apenas versões (muitas vezes simplificadas e estereotipadas) de fatos, comprometidas com projetos políticos determinados, as quais, se por um lado não podem ser genericamente cerceadas, podem eventualmente ser restringidas em caso de colisão com direitos fundamentais de igual hierarquia constitucional. A desmistificação ora propugnada visa pôr em discussão a premissa de que toda e qualquer medida restritiva ao discurso se consubstancia em atentado contra a sagrada atuação da imprensa como única instituição depositária dos valores democráticos no Estado brasileiro. ${ }^{211}$

\footnotetext{
206 Ibid. P. 381.

207 A professora segue sua explanação ilustrando a aplicação do referido parâmetro: "Exemplificando, se o conflito envolver a vinculação na mídia de provas ilícitas, tal elemento jogará a favor do fair trial justificando no caso a imposição de restrição à liberdade de expressão. Ao passo que, se estiver em jogo a regra da preservação do sigilo da fonte, eventual colisão pode ser resolvida a favor da liberdade de expressão.” Ibid. P. 381-382.

${ }^{208}$ Ibid. P. 382.

${ }^{209}$ Ibid. P. 264.

${ }^{210}$ Ibid. P. 243

${ }^{211}$ Ibid. P. 366.
} 
Ao final, a professa sugere uma série de medidas que entende apropriadas à colisão estudada. Um primeiro grupo inclui medidas que não restringem a liberdade de expressão, mas podem ser pouco idôneas para realização do julgamento justo. São elas: 1. questionário e instrução dos jurados; 2. desaforamento (que deve poder ser aplicado mesmo fora do Júri); 3. postergação do julgamento; 4. sequestro de jurados; 5. vedação de provas produzidas pela mídia no processo. ${ }^{212} \mathrm{Na}$ hipótese de se mostrarem insuficientes, um segundo grupo traz medidas restritivas da liberdade de expressão que podem ser fixadas de acordo com a intensidade do discurso midiático: 1. ampliação do direito de resposta; 2. restrição da publicidade do julgamento; 3. imposição de punições posteriores à publicação; 4. ordem judicial de proibição de divulgação de provas ilícitas; 5. ordem judicial de proibição temporária de veiculação de notícias sobre o julgamento. ${ }^{213}$

Impende observar que o trabalho de Simone pretende dar resposta ao impacto da mídia tradicional sobre o devido processo legal considerado sob uma perspectiva singularizada. Diferentemente, a preocupação aqui esboçada consiste na ingerência do discurso dos meios de comunicação social sobre as garantias contra o poder punitivo, especialmente a presunção de inocência, sob uma abordagem generalizada. A partir disso, é possível afirmar que as louváveis sugestões da referida penalista podem auxiliar na superação da inobservância da presunção de inocência como instituição jurídica apenas na hipótese de serem amplamente aplicadas. Influenciar a repetida postura dos mecanismos comunicacionais exige uma adesão não pontual, mas massiva do Judiciário a medidas como as propostas por ela.

$\mathrm{Na}$ jurisprudência brasileira, encontra-se recentes julgados que vedam a exposição involuntária da imagem de presos provisórios pelos agentes do Estado, ressalvando hipóteses excepcionais em que a divulgação terá de ser idoneamente fundamentada pela autoridade competente. Por iniciativa de Defensorias Públicas de diferentes estados da federação, o

212 Para mais informações, vide Ibid. P. 384-393.

${ }^{213}$ Para mais informações, vide Ibid. P. 393-404. 
Juízo da $17^{\mathrm{a}}$ Vara da Fazenda Pública da Comarca de Maceió, bem como os Tribunais de Justiça de Minas Gerais e do Rio de Janeiro foram provocados a sopesar os direitos dos presos à honra, à imagem e à integridade moral, bem como ao estado de inocência, com a liberdade de expressão e de informação.

Em 2017, no bojo da ação civil pública $\mathrm{n}^{\circ}$ 070632353.2017.8.02.0001, o Juízo de Alagoas deferiu parcialmente a liminar requerida pela Defensoria Pública do Estado afirmando não ser possível a exposição involuntária e sensacionalista dos detentos que sequer tiveram sua culpa formada e, ademais, repreendendo colaborações entre agentes públicos e meios de comunicação que visem o referido fím. Em 2018, nos autos do agravo de instrumento $\mathrm{n}^{\mathrm{o}} 1.0000 .18 .108797-4 / 001$, o relator do recurso na Primeira Câmara Cível do Tribunal de Justiça de Minas Gerais concedeu parcialmente a antecipação de tutela recursal requerida pela respectiva Defensoria reconhecendo que "a exposição desnecessária dos presos ocorre diariamente e são de fácil acesso nos meios de comunicação.” 214 Em 2019, ao julgar a apelação n no 013136609.2013.8.19.0001, a Terceira Câmara Cível do Tribunal de Justiça do Rio de Janeiro manteve a sentença de primeiro grau que acolheu os pedidos da Defensoria Pública, o que fez usando as teorias de Alexy, Dworkin e Barcellos sobre ponderação de direitos fundamentais. Esta Corte frisou que a livre expressão pode sofrer restrições em razão do "caráter precipuamente sigiloso de investigações criminais" e da "tutela da intimidade e imagem das pessoas envolvidas e que já se encontram sob a tutela estatal"215. A proteção do indivíduo foi destacada e a cautela em sua exposição exigida, especialmente pela prevalência da presunção de inocência em favor dos acusados sem condenação criminal definitiva.

\footnotetext{
${ }^{214}$ Trecho retirado da decisão do relator, Desembargador Alberto Vilas Boas.

${ }^{215}$ Trecho retirado da ementa do acórdão da Terceira Câmara Civil do Tribunal de Justiça do Rio de Janeiro na apelação ${ }^{\circ}$ 0131366-09.2013.8.19.0001.
} 
Ressalte-se que a decisão do Tribunal de Justiça do Rio de Janeiro foi objeto de recursos extraordinários interpostos pela Procuradoria Geral do Estado do Rio de Janeiro e pelo Ministério Público do Rio de Janeiro. Os referidos recursos se encontram na Terceira Vice-Presidência do Tribunal estadual para um primeiro juízo de admissibilidade. Caso sejam remetidos ao Supremo Tribunal Federal, a Corte Suprema do país terá a oportunidade de se manifestar sobre a obrigação de não fazer imposta aos agentes estatais pelas decisões impugnadas, consubstanciada em não expor a imagem de presos provisórios, salvo em situações excepcionais e justificadas. A consolidação desta tese se releva extremamente relevante, eis que os mecanismos de responsabilização de abusos na exposição de imputados comumente mobilizados até hoje pela Justiça operam a posteriori, sendo insuficientes para sanar os prejuízos decorrentes desta prática. A proposta apresentada pelas Defensorias Públicas e acolhida pelos Juízos mencionados, por sua vez, é capaz de se antecipar ao dano que surge da exposição da figura dos acusados sem aviltar o direito à informação. A sua implementação definitiva tem o potencial de contribuir para obstar condutas deletérias da criminologia midiática - como a dramatização do fato criminoso - e efeitos deste discurso - como a criação de estereótipos para seres supostamente perigosos -, sem impedir que dados sobre o suposto fato criminoso e o encarceramento do suspeito sejam divulgados.

No direito comparado, diversos Estados adotam dispositivos legais que limitam a liberdade de expressão, especialmente em prestígio das garantias que protegem o indivíduo demandado pelo sistema penal. É possível citar a França e a Áustria como países que, inclusive, criminalizam determinadas condutas relativas à exposição prejudicial do imputado e do fato delituoso. Os Estados mencionados merecem o destaque ora realizado, uma vez que possuem tradições jurídicas semelhantes à brasileira e ostentam uma história de proteção das liberdades. 
O Código Penal Francês, no artigo 434-16, prevê como crime de obstrução ao exercício da justiça publicar, antes da decisão final, comentários tendentes a exercer pressão para influenciar o depoimento de testemunhas ou a decisão dos Juízos de instrução ou de julgamento ${ }^{216}$. Além disso, a Lei francesa sobre a liberdade de imprensa dispõe acerca de crimes próprios dos profissionais dos meios de comunicação, punindo com multa a conduta de divulgar imagem de pessoa algemada ou sendo presa provisoriamente antes do seu julgamento. Equiparada a esta prática é o fato de publicar, produzir ou comentar a culpa de pessoa ainda não sentenciada. É também delito reprimido com multa publicar acusações antes de serem lidas em audiência pública e disseminar notícias falsas de má-fé. ${ }^{217}$ De forma similar, a Lei de Mídias da Áustria, na seção 23, define como influência proibida em julgamentos criminais os atos de discutir o possível

\footnotetext{
${ }^{216}$ Code penal. Partie législative. Livre IV: Des crimes et délits contre la nation, l'Etat et la paix publique. Titre III : Des atteintes à l'autorité de l'Etat. Chapitre IV : Des atteintes à l'action de justice. Section 2 : Des entraves à l'exercice de la justice. Article 434-16. La publication, avant l'intervention de la décision juridictionnelle définitive, de commentaires tendant à exercer des pressions en vue d'influencer les déclarations des témoins ou la décision des juridictions d'instruction ou de jugement est punie de six mois d'emprisonnement et de 7500 euros d'amende. Lorsque l'infraction est commise par la voie de la presse écrite ou audiovisuelle, les dispositions particulières des lois qui régissent ces matières sont applicables en ce qui concerne la détermination des personnes responsables.

${ }^{217}$ Loi du 29 juillet 1881 sur la liberté de la presse. Chapitre IV: Des crimes et delits commis par la voie de la presse ou par tout autre moyen de publication. Paragraphe 2 : Délits contre la chose publique. Article 27. La publication, la diffusion ou la reproduction, par quelque moyen que ce soit, de nouvelles fausses, de pièces fabriquées, falsifiées ou mensongèrement attribuées à des tiers lorsque, faite de mauvaise foi, elle aura troublé la paix publique, ou aura été susceptible de la troubler, sera punie d'une amende de 45000 euros.

Les mêmes faits seront punis de 135000 euros d'amende, lorsque la publication, la diffusion ou la reproduction faite de mauvaise foi sera de nature à ébranler la discipline ou le moral des armées ou à entraver l'effort de guerre de la Nation.

Paragraphe 3 : Délits contre les personnes. Article 35 quater. La diffusion, par quelque moyen que ce soit et quel qu'en soit le support, de la reproduction des circonstances d'un crime ou d'un délit, lorsque cette reproduction porte gravement atteinte à la dignité d'une victime et qu'elle est réalisée sans l'accord de cette dernière, est punie de 15000 euros d'amende.

Paragraphe 5: Publications interdites, immunités de la défense. Article 38. Il est interdit de publier les actes d'accusation et tous autres actes de procédure criminelle ou correctionnelle avant qu'ils aient été lus en audience publique et ce, sous peine d'une amende de 3750 euros.

Sans préjudice des dispositions de l'article 15 du code pénal, il est interdit, sous la même peine, de publier aucune information relative aux travaux et délibérations du conseil supérieur de la magistrature, à l'exception des informations concernant les audiences publiques et les décisions publiques rendues en matière disciplinaire à l'encontre des magistrats. Pourront toutefois être publiées les informations communiquées par le président d'une formation du Conseil supérieur.
} 
resultado de procedimentos penais ou o valor de provas produzidas no processo, fixando a pena de multa para repreendê-los. ${ }^{218}$

Interessante pontuar que tal tipo penal foi usado na conhecida condenação do jornalista Alfred Worm pela publicação de artigo sobre o julgamento de Hannes Androsch, antigo Ministro da Fazenda da Áustria. Na matéria, Worm criticava a defesa de Androsch e comentava sua culpa pela prática de delitos pelos quais ainda não havia sido sentenciado. A condenação de Worm na Justiça Austríaca foi submetida à Corte Europeia de Direitos Humanos, a qual considerou que a decisão interna não ofendia a liberdade de expressão, notadamente pela necessidade de preservar a autoridade e imparcialidade do Judiciário. ${ }^{219}$

A convencionalidade da decisão do Estado Austríaco se lastreia na definição e delimitação do direito à liberdade de expressão trazido pela Convenção Europeia de Direitos Humanos. O artigo $10^{220}$ do referido diploma internacional dispõe que a lei interna de um Estado pode restringir a livre expressão não apenas em prestígio à autoridade e imparcialidade do Judiciário, mas também em favor da honra e dos direitos de outrem, bem como em atenção a outros interesses.

\footnotetext{
${ }^{218}$ Verbotene Einflußnahme auf ein Strafverfahren. \$ 23. Wer in einem Medium während eines Hauptverfahrens nach Rechtswirksamkeit der Anklageschrift, im Verfahren vor dem Einzelrichter des Landesgerichts oder im bezirksgerichtlichen Verfahren nach Anordnung der Hauptverhandlung, vor dem Urteil erster Instanz den vermutlichen Ausgang des Strafverfahrens oder den Wert eines Beweismittels in einer Weise erörtert, die geeignet ist, den Ausgang des Strafverfahrens zu beeinflussen, ist vom Gericht mit Geldstrafe bis zu 180 Tagessätzen zu bestrafen.

${ }^{219}$ Caso Worm vs. Áustria, julgado em 29 de agosto de 1997 pela Corte Europeia de Direitos Humanos. Sentença disponível em: < http://www.fundacionpombo.org/wpcontent/uploads/2012/06/STEDH-caso-Worm-versus-Austria.pdf >. Acesso em 15/11/19.

${ }^{220}$ ARTIGO $10^{\circ}$. Liberdade de expressão. 1. Qualquer pessoa tem direito à liberdade de expressão. Este direito compreende a liberdade de opinião e a liberdade de receber ou de transmitir informações ou ideias sem que possa haver ingerência de quaisquer autoridades públicas e sem considerações de fronteiras. $\mathrm{O}$ presente artigo não impede que os Estados submetam as empresas de radiodifusão, de cinematografia ou de televisão a um regime de autorização prévia.

2. O exercício desta liberdades, porquanto implica deveres e responsabilidades, pode ser submetido a certas formalidades, condições, restrições ou sanções, previstas pela lei, que constituam providências necessárias, numa sociedade democrática, para a segurança nacional, a integridade territorial ou a segurança pública, a defesa da ordem e a prevenção do crime, a proteção da saúde ou da moral, a protecção da honra ou dos direitos de outrem, para impedir a divulgação de informações confidenciais, ou para garantir a autoridade e a imparcialidade do poder judicial.
} 
A apresentação destes exemplos de jurisdições diferentes da brasileira não serve para sustentar a criminalização de abusos da liberdade de expressão. Tal sugestão seria, inclusive, extremamente contraditória em um trabalho que se propõe a criticar o poder de punir e seus mecanismos adjacentes. $\mathrm{Na}$ verdade, observar as ilustrações citadas de direito estrangeiro e internacional pode contribuir para que se perceba que limitar a expressão livre não é obrigatoriamente incompatível com o Estado Democrático de Direito. Diante do vácuo legislativo que existe no Brasil sobre o tema, a criação de quaisquer regras que especificassem os limites da liberdade de expressão, considerando direitos como a presunção de inocência, seria formidável. A edição de comandos legais poderia, com previsibilidade e alcance geral, ser eficaz na frustração do modelo de conduta repetido da criminologia midiática. 


\section{CONCLUSÃO}

Neste trabalho, buscou-se assinalar como se relacionam o discurso criminológico (teoria que pensa a questão criminal), a prática do poder punitivo (aparato, comumente vinculado ao poder público, de disposição monopolista da força para resolver conflitos sociais confiscados da vítima) e a presunção de inocência (garantia jurídica de que toda pessoa acusada de um delito seja considerada inocente até a comprovação legal de sua culpa).

Uma análise histórica permitiu notar que os pensamentos autoritários sobre o crime ou a conduta desviante sustentaram expressões do poder de punir mais repressivas e contrárias ao referido direito. Por outro lado, reparou-se que as teorias que prestigiaram a liberdade e a igualdade dos indivíduos e que foram anunciadas ao longo dos anos influenciaram expressões da potestade punitiva mais moderadas e protetoras da presunção de inocência.

Dentro deste contexto, elegeu-se como objeto específico de estudo a relação do poder de punir e da presunção de inocência com a criminologia midiática (entendida como o discurso dos meios de comunicação social sobre a questão criminal).

Verificou-se que a principal palavra dos veículos de informação sobre o delito, de amplo alcance junto ao campo social, distorce ou reduz a realidade fazendo crer que os perseguidos pelo sistema criminal são seres perigosos e causadores de toda a angústia da população, motivo pelo qual precisariam ser excluídos.

Por meio de uma abordagem superficial, descontínua e acrítica, os mecanismos tradicionais de comunicação social estimulam, junto ao campo social, o temor e a vingança contra a figura do delinquente. Tal ruptura entre as pessoas aparentemente decentes e o estereótipo do criminoso maligno é perpetuada pela esfera da mídia eletrônica caracterizada pelo 
fechamento das pessoas em bolhas de conteúdo escolhidas pelas próprias ou por algoritmos.

Todo este pensamento midiático avesso ao criminoso se mantém principalmente por afigurar uma tendência que supostamente beneficia as categorias dominantes da sociedade, grandes influenciadoras das plataformas midiáticas.

Daí decorre o clamor irracional por punição urgente e exemplar que não se coaduna com a espera na aplicação de pena para os acusados ou com a necessidade de se demonstrar minuciosamente a existência do crime e a sua autoria para que sejam repreendidos - normas estas que derivam do direito à presunção de inocência. $\mathrm{Na}$ verdade, a criminologia midiática impulsiona o agigantamento do poder de punir e rejeita os limites a ele impostos pela presunção de inocência, percebendo-a como norma que atrapalha a adequada resolução dos conflitos da sociedade.

Este discurso dos veículos de informação se assemelha a teorias autoritárias historicamente ultrapassadas e contribui para que a presunção de inocência, apesar de tranquilamente prevista em vários diplomas jurídicos, não seja efetivamente incorporada na prática da sociedade, notadamente na brasileira.

Observou-se que, ainda que a presunção de inocência seja aclamada pela doutrina como censor da qualidade democrática de um Estado e assentada em diversos ordenamentos jurídicos como regra-chave de um processo penal garantista, o estado de inocência tem dificuldades para ser concretizado no país. A adesão da jurisprudência ao invento do in dubio pro societate, o elevadíssimo número de presos provisórios nos cárceres do país e a postura dos seus Poderes Legislativo e Judiciário frente à imposição de sanções decorrentes da culpa por um crime antes do trânsito em julgado de sentença penal condenatória revelam que nem mesmo os atores jurídicos brasileiros - que deveriam tutelar os direitos - resguardam devidamente a presunção de inocência. 
O referido prejuízo que o discurso midiático (legitimante da prática punitiva) impõe à presunção de inocência precisa ser evitado. São, pelo menos, dois relevantes motivos que apontam para tanto.

Em primeiro lugar, a periculosidade da expansão do poder de punir. Uma análise dos massacres ocorridos ao longo da história, feita por Raúl Zaffaroni, o evidencia ao revelar que numerosos assassinatos em massa foram executados pelo poder de punir ilimitado. Esta aterrorizante realidade não é pontual e tampouco se encontra distante. Na verdade, o risco de o poder punitivo se descontrolar está sempre presente e se encontra próximo em tempo e em espaço, o que é notado pelo massacre a conta gostas que se verifica no Brasil contra um setor jovem, negro e pobre da população. Neste cenário, é certo que, ao desacreditar as garantias que exercem a contenção do poder de punir, a criminologia midiática acelera o caminho para o massacre e merece a rejeição.

Em segundo lugar, o fato de que o referido discurso não está resguardado juridicamente demonstra a necessidade de se obstar a relação descrita entre a criminologia midiática e o estado de inocência. Isto porque a liberdade de expressão não é reconhecida como um direito absoluto e precisa ser objeto de ponderação na hipótese de o seu exercício produzir consequências negativas para um direito fundamental de outrem. No caso em comento, a teoria criminológica da mídia usufrui de uma liberdade de expressão irrestrita que degenera intensamente a presunção de inocência enquanto norma que se destina ao caro valor de proteger o indivíduo contra os mecanismos de violência do Estado. Por mais esta razão, não merece se manter.

Algumas medidas foram enunciadas como propostas que podem ser mobilizadas no sentido de superar a prejudicialidade do discurso dos meios de comunicação social sobre a presunção de inocência. São elas: (i) estimular que profissionais da comunicação aprendam sobre o sistema criminal principalmente por meio de uma perspectiva criminológica; (ii) 
diversificar os ocupantes da comunicação de massa, abrindo espaço para que criminólogos possam expandir o conhecimento da academia para além das universidades; (iii) adotar as sugestões de Simone Schreiber a fim de superar o conflito liberdade de expressão e de informação versus direito a um julgamento criminal justo nos casos concretos; (iv) consolidar teses que permitam a atuação a priori da vedação da exposição de imputados, como a proibição da divulgação involuntária da imagem de presos provisórios pelos agentes do Estado encontrada na jurisprudência pátria; e (v) criar regras jurídicas específicas que limitem a liberdade de expressão considerando direitos como a presunção de inocência, à luz do direito comparado.

$\mathrm{O}$ presente trabalho pretendeu contribuir para identificar que a cobertura do delito feita pela mídia não ofende apenas o acusado exposto, mas prejudica a presunção de inocência como direito de todos. Este estudo tem, ainda, a ambição de encorajar mudanças no destrutivo discurso dos meios de comunicação social sobre a questão criminal no sentido de garantir que a palavra que atinge todo o campo social sobre o delito seja menos punitivista e menos letal. 


\section{REFERÊNCIAS BIBLIOGRÁFICAS}

ALEXY, Robert. Colisão de Direitos Fundamentais e Realização de Direitos Fundamentais no Estado de Direito Democrático. Revista da Faculdade de Direito da Universidade Federal do Rio Grande do Sul, v. $17,1999.13 \mathrm{p}$.

ALBUQUERQUE, Ana Luiza. Morte por intervenção do Estado atinge maior patamar em 20 anos no Rio. Folha de S. Paulo, 21 ago. 2019. Disponível em: < https://www1.folha.uol.com.br/cotidiano/2019/08/mortepor-intervencao-do-estado-atinge-maior-patamar-em-20-anos-no-rio.shtml >. Acesso em 28/10/19.

ÁVILA, Humberto. Teoria dos princípios - da definição à aplicação dos princípios jurídicos. $4^{\mathrm{a}}$ ed.. São Paulo: Malheiros Editores, 2005. 138 p.

BARCELloS, Ana Paula de. Ponderação, racionalidade e atividade jurisdicional. Rio de Janeiro: Renovar, 2005. 334 p.

BATISTA, Nilo. Mídia e sistema penal no capitalismo tardio. Biblioteca on-line de ciências de comunicação, 2003. Disponível em: < http://www.bocc.ubi.pt/pag/batista-nilo-midia-sistema-penal.pdf $>$. Acesso em: 01/08/2019. 20 p.

BATISTA, Vera Malaguti. Introdução crítica à criminologia brasileira. $2^{\mathrm{a}}$ ed.. Rio de Janeiro: Revan, 2012. 126 p.

BECCARIA, Cesare Bonesana Marchesi di. Dos delitos e das penas. $3^{\mathrm{a}}$ ed.. São Paulo: Martins Fontes, 2005. 139 p.

BOURDIEU, Pierre. Sobre a televisão. Rio de Janeiro, Zahar, 1997. 143 p.

BRANCO, Sérgio. Fake News e os Caminhos para Fora da Bolha. Revista Interesse Nacional, 2017. Disponível em: < https://itsrio.org/wpcontent/uploads/2017/08/sergio-fakenews.pdf $>$ Acesso em 20/08/19. 11 p. 
BUENO, Samira; LIMA, Renato Sérgio de. Anuário brasileiro de segurança pública 2019. Fórum Brasileiro de Segurança Pública, a. 13, 2019. Disponível em: < http://www.forumseguranca.org.br/wpcontent/uploads/2019/09/Anuario-2019-FINAL-v3.pdf >. Acesso em 20/11/19.

CARNELUTTI, Francesco. As misérias do processo penal. São Paulo: Editora Pilares, 2009. 127 p.

CARVALHO, Catarina. "A tendência natural do poder é controlar a imprensa", diz jornalista espanhol. Folha de S. Paulo, 17 ago. 2019. Disponível em: < https://www1.folha.uol.com.br/poder/2019/08/atendencia-natural-do-poder-e-controlar-a-imprensa-diz-jornalistaespanhol.shtml >. Acesso em 05/09/2019.

CARVALHO, L. G. Grandinetti Castanho de. Processo penal e constituição: Princípios constitucionais do processo penal. $5^{\mathrm{a}}$ ed.. Rio de Janeiro: Editora Lumen Juris, 2009. 353 p.

CASARA, Rubens R R. Processo penal do espetáculo: e outros ensaios. $2^{\mathrm{a}}$ ed.. Florianópolis: Tirant lo Blanch, 2018. 248 p.

CORTE EUROPEIA DE DIREITOS HUMANOS, Caso Worm v. Austria: Application 22.714/93. Estrasburgo, 29 ago. 1997.

DELMAZO, Caroline; VALENTE, Jonas C.L.. Fake news nas redes sociais online: propagação e reações à desinformação em busca de cliques. Media \& Jornalismo, Lisboa, v. 18, n. 32, p. 155-169, abr. 2018. Disponível em $<$ http://www.scielo.mec.pt/pdf/mj/v18n32/v18n32a12.pdf $>$. Acesso em 04/09/2019. $15 \mathrm{p}$.

FERRAJOLI, Luigi. Direito e razão: teoria do garantismo penal. $3^{\mathrm{a}}$ ed.. rev. São Paulo: Editora Revista dos Tribunais, 2002. 766 p.

FOUCAULT, Michel. Vigiar e punir: nascimento da prisão. $42^{\mathrm{a}}$ ed.. Rio de Janeiro: Vozes, 2014. 301 p. 
GIRARD, René. O bode expiatório. São Paulo: Paulus, 2004. 276 p.

GRAGNANI, Juliana. Um Brasil dividido e movido a notícias falsas: uma semana dentro de 272 grupos políticos no WhatsApp. BBC Brasil, 5 out. 2018. Disponível em: < https://www.bbc.com/portuguese/brasil$45666742>$. Acesso em 05/09/2019.

GREENWALD, Glenn; NEVES, Rafael. As mensagens secretas da Lava Jato Parte 18: Em chats, procuradores admitem "vazamentos". Num episódio, Dallagnol antecipou passo da operação ao Estadão para pressionar suspeito. The Intercept Brasil, 29 ago 2019. Disponível em: < https://theintercept.com/2019/08/29/lava-jato-vazamentos-imprensa/ >. Acesso em 01/09/19.

LOPES JUNIOR, Aury. Direito Processual Penal. 14 ${ }^{\mathrm{a}}$ ed.. São Paulo: Saraiva, 2017. 1149 p.

MACHADO, Caio; KONOPACKI, Marco. Poder Computacional: Automação no uso do WhatsApp nas Eleições. Rio de Janeiro: Instituto de Tecnologia e Sociedade do Rio de Janeiro, 2018. Disponível em: < https://itsrio.org/pt/publicacoes/automacao-eleicoes/ >. Acesso em 05/09/2019.

MACHADO, Jónatas E. M. Liberdade de expressão - Dimensões Constitucionais da esfera pública no sistema social. Coimbra: Coimbra editora. 2002. $1196 \mathrm{p}$.

MAGRANI, Eduardo. Democracia conectada: a internet como ferramenta de engajamento político-democrático. Curitiba: Juruá, 2014. 222p.

MARINONI, Bruno. Desinformação: ameaça ao direito à comunicação muito além das fake news. São Paulo: Intervozes - Coletivo Brasil de Comunicação Social, jul. 2019. Disponível em: < https://intervozes.org.br/publicacoes/desinformacao-ameaca-ao-direito-acomunicacao-muito-alem-das-fake-news/ >. Acesso em 05/09/2019. 46 p.

MORAES, Maurício Zanoide de. Presunção de inocência no processo penal brasileiro: análise de sua estrutura normativa para a elaboração 
legislativa e para a decisão judicial. Rio de Janeiro: Lumen Juris, 2010. 567 p.

MORO, Sergio Fernando. Considerações sobre a operação mani pulite. Revista CEJ, Brasília, n. 26, p. 56-62, jul./set. 2004. Disponível em < https://www.conjur.com.br/dl/artigo-moro-mani-pulite.pdf >. Acesso em 01/09/2019. 7 p.

MOURA, Marcos Vinicius. Levantamento Nacional de Informações Penitenciárias. Atualização - Junho de 2017. Brasília: Ministério da Justiça e Segurança Pública. Departamento Penitenciário Nacional, 2019. Disponível em:

http://depen.gov.br/DEPEN/depen/sisdepen/infopen/relatorios-

sinteticos/infopen-jun-2017-rev-12072019-0721.pdf > Acesso em 03/10/2019. $74 \mathrm{p}$.

NEWMAN, Nic; FLETCHER, Richard; KALOGEROPOULOS, Antonis; LEVY David A. L.; NIELSEN, Rasmus Kleis. Reuters Institute Digital News Report 2018. Oxford: Reuters Institute for the study of journalism, 2018. Disponível em: < http://media.digitalnewsreport.org/wpcontent/uploads/2018/06/digital-news-report-2018.pdf?x89475 >. Acesso em 26/08/2019. 143 p.

NUNES, Pablo. Crime e polícia no \#RiodeJaneiro: Relatos em páginas do Facebook. Boletim Segurança e Cidadania, n. 24, outubro de 2017. Disponível em: < https://www.ucamcesec.com.br/boletim/crime-e-policiano-riodejaneiro-relatos-em-paginas-do-facebook/ >. Acesso em 12/09/19. $35 \mathrm{p}$.

OMO, Rosa Del. A América Latina e sua criminologia. Rio de Janeiro: Revan, 2004.

PARKINSON, Hannah Jane. Click and elect: how fake news helped Donald Trump win a real election. The Guardian, 14 nov. 2016. Disponível em: < https://www.theguardian.com/commentisfree/2016/nov/14/fake-newsdonald-trump-election-alt-right-social-media-tech-companies >. Acesso em 04/09/2019. 
PASQUINI, Patrícia. 90\% dos eleitores de Bolsonaro acreditaram em fake news, diz estudo. Folha de S. Paulo, 2 nov. 2018. Disponível em: < https://www1.folha.uol.com.br/poder/2018/11/90-dos-eleitores-de-

bolsonaro-acreditaram-em-fake-news-diz-estudo.shtml >. Acesso em 04/09/2019.

RAMOS, Silvia; PAIVA, Anabela. Mídia e violência: tendências na cobertura de criminalidade e segurança no Brasil. Rio de Janeiro: IUPERJ, 2007. $191 \mathrm{p}$.

RAMOS, Silvia; PAIVA, Anabela; NUNES, Pablo. Mídia e violência: O que mudou em uma década? - Relatório preliminar de análise de jornais impressos. Rio de Janeiro: Centro de Estudos de Segurança e Cidadania (CESEC) / Universidade Cândido Mendes, mai. 2017. Disponível em: < https://www.ucamcesec.com.br/wp-content/uploads/2016/10/Midia-eViolencia 2016_Versao4.pdf >. Acesso em 13/08/19. 39 p.

ROSENBERG, Matthew; CONFESSORE, Nicholas; CADWALLADR, Carole. How Trump Consultants Exploited the Facebook Data of Millions. The New York Times, 18 mar. 2018. Disponível em: < https://www.nytimes.com/2018/03/17/us/politics/cambridge-analyticatrump-campaign.html >. Acesso em 02/09/2019.

SANTOS, Thandara; ROSA, Marlene Inês da. Levantamento nacional de informações penitenciárias: INFOPEN Atualização - Junho de 2016. Brasília: Ministério da Justiça e Segurança Pública. Departamento Penitenciário Nacional, 2017. Disponível em: < http://depen.gov.br/DEPEN/noticias-1/noticias/infopen-levantamentonacional-de-informacoes-penitenciarias-2016/relatorio_2016_22111.pdf>. Acesso em 03/10/2019. 65 p.

SCHREIBER, Simone. A publicidade opressiva de julgamentos criminais Uma investigação sobre as consequências e formas de superação da colisão entre a liberdade de expressão e informação e o direito ao julgamento criminal justo, sob a perspectiva da Constituição brasileira de 1988. Rio de Janeiro: Renovar, 2008. 426 p.

SUPERIOR TRIBUNAL DE JUSTIÇA, Agravo Regimental no Agravo em Recurso Especial 1464941 / Goiás, Sexta Turma, Relatora Ministra Laurita Vaz, Brasília, 03 set. 2019. 
SUPERIOR TRIBUNAL DE JUSTIÇA, Agravo Regimental no Habeas Corpus 466.216 / RIO DE JANEIRO, Quinta Turma, Relator Ministro Ribeiro Dantas, 10 set. 2019.

SUPERIOR TRIBUNAL DE JUSTIÇA, Recurso Especial 1.689.173 / SANTA CATARINA, Sexta Turma, Relator Ministro Rogerio Schietti Cruz, Brasília, 21 nov. 2017.

SUPREMO TRIBUNAL FEDERAL, Ação Declaratória de Constitucionalidade 30 / DISTRITO FEDERAL, Tribunal Pleno, Relator Ministro Luiz Fux, Brasília, 16 fev. 2012.

SUPREMO TRIBUNAL FEDERAL, Ação Declaratória de Constitucionalidade 43 / DISTRITO FEDERAL, Tribunal Pleno, Relator Ministro Marco Aurélio, Brasília, 07 nov. 2019.

SUPREMO TRIBUNAL FEDERAL, Ação Declaratória de Constitucionalidade 44 / DISTRITO FEDERAL, Tribunal Pleno, Rel. Ministro Marco Aurélio, Brasília, 07 nov. 2019.

SUPREMO TRIBUNAL FEDERAL, Ação Declaratória de Constitucionalidade 54 / DISTRITO FEDERAL, Tribunal Pleno, Relator Ministro Marco Aurélio, Brasília, 07 nov. 2019.

SUPREMO TRIBUNAL FEDERAL, Ação Declaratória de Inconstitucionalidade 4578 / ACRE, Tribunal Pleno, Relator Ministro Luiz Fux, Brasília, 16 fev. 2012.

SUPREMO TRIBUNAL FEDERAL, Agravo em Recurso Extraordinário 1.067.392, Segunda Turma, Relator Ministro Gilmar Mendes, Brasília, 26 fev. 2019.

SUPREMO TRIBUNAL FEDERAL, Ação Originária 2275 / RIO GRANDE DO NORTE, Primeira Turma, Relator Ministro Luiz Fux, Brasília, 23 out. 2018. 
SUPREMO TRIBUNAL FEDERAL, Habeas Corpus 126.292 / SÃO PAULO, Tribunal Pleno, Relator Ministro Teori Zavascki, Brasília, 17 fev. 2016.

SUPREMO TRIBUNAL FEDERAL, Habeas Corpus 84.078 / MINAS GERAIS, Tribunal Pleno, Relator Ministro Eros Grau, Brasília, 05 fev. 2009.

The World's Most Valuable Resource is no Longer Oil, but Data. The Guardian, 06 mai. 2017. Disponível em: < https://www.economist.com/leaders/2017/05/06/the-worlds-most-valuableresource-is-no-longer-oil-but-data >. Acesso em 02/09/2019.

TRIBUNAL DE JUSTIÇA DO ESTADO DE ALAGOAS, Ação Civil Pública ${ }^{\circ}$ 0706323-53.2017.8.02.0001, $17^{\text {a }}$ Vara Civil da Capital, Juiz de direito Alberto Jorge Correia de Barros Lima, Alagoas, 22 mar. 2017.

TRIBUNAL DE JUSTIÇA DO ESTADO DE MINAS GERAISs, Agravo de Instrumento na Ação Civil Pública no 1.0000.18.108797-4/001, Primeira Câmara Cível, Relator Desembargador Alberto Vilas Boas, Minas Gerais, 05 out. 2018.

TRIBUNAL DE JUSTIÇA DO ESTADO DO RIO DE JANEIRO, Apelação 0131366-09.2013.8.19.0001, Terceira Câmara Cível, Relatora Desembargadora Renata Machado Cotta, Rio de Janeiro, 13 mar. 2019.

UNESCO. Desinformação (fake news). Genebra: UNESCO, 2017. Disponível em: < http://www.unesco.org/new/pt/brasilia/communicationand-information/freedom-of-expression/mediadevelopment/disinformation/ >. Acesso em 02/09/2019.

VICTOR, Fabio. Como funciona a engrenagem das notícias falsas no Brasil. Folha de S. Paulo, 19 fev. 2017. Disponível em: < https://www1.folha.uol.com.br/ilustrissima/2017/02/1859808-comofunciona-a-engrenagem-das-noticias-falsas-no-brasil.shtml >. Acesso em $02 / 09 / 2019$. 
VIEIRA, Ana Lúcia Menezes. Processo penal e mídia. São Paulo: Editora Revista dos Tribunais, 2003.

ZACCONE, Orlando. Indignos de vida: a forma jurídica da política de extermínio de inimigos na cidade do Rio de Janeiro. Rio de Janeiro: Revan, 2015. 280 p.

ZAFFARONI, Eugenio Raul; BATISTA, Nilo; ALAGIA, Alejandro; SLOKAR, Alejandro. Direito Penal Brasileiro: primeiro volume - Teoria Geral do Direito Penal. 4a ed.. Rio de Janeiro: Revan, 2011. 660 p.

ZAFFARONI, Eugenio Raúl. A questão criminal. Rio de Janeiro: Revan, 2013. 319 p.

ZAFFARONI, Eugenio. O inimigo no direito penal. $3^{\text {a }}$ ed.. Rio de Janeiro: Revan, 2007. 224 p.

ZILLI, Luís Felipe. Letalidade e Vitimização Policial: características gerais do fenômeno em três estados brasileiros. Boletim de análise política institucional, n. 17, dez. 2018. Disponível em: < http://repositorio.ipea.gov.br/bitstream/11058/8873/1/bapi_17_cap_10.pdf $>$. Acesso em 24/10/19. 